\title{
AVALIAÇÃO DO ESTADO NUTRICIONAL DE OPERADORES DE TELEMARKETING SUBMETIDOS \\ A TRÊS TURNOS FIXOS DE TRABALHO
}

MARIA FERNANDA CRISTOFOLETTI

Dissertação de Mestrado apresentada na área de concentração Saúde Ambiental da Faculdade de

Saúde Pública da Universidade de São Paulo para obtenção do título de Mestre.

ORIENTADORA: Prof. Dra. Lys Esther Rocha

São Paulo 
Autorizo, exclusivamente para fins acadêmicos e científicos, a reprodução total ou parcial desta dissertação, por processos fotocopiadores.

Assinatura:

Data: 
Dedicatória

Aos meus pais, irmãos e minha sobrinha Júlia 


\section{Agradecimentos}

À Profa. Dra. Lys Esther Rocha pelo aprendizado, dedicação, compreensão e orientação durante todo o período do mestrado.

As Profas. Dras. Marly Augusto Cardoso e Suely Gimeno pelo aprendizado na fase da pré-banca.

À Profa. Dra. Cláudia Roberta de Castro Moreno pela compreensão e aprendizado.

Às centrais de telemarketing pela possibilidade de realização desta pesquisa.

Ao Conselho Nacional de Desenvolvimento Tecnológico (Cnpq) pela bolsa concedida.

Às bibliotecárias da Biblioteca da Faculdade de Saúde Pública pela colaboração no auxílio do desenvolvimento dessa dissertação.

À equipe da sala de informática da pós-graduação que sempre auxiliou em todas as situações.

À minha família, em especial aos meus pais Tadeu e Cecília, pela força e coragem de encarar esse desafio.

Aos colegas e amigos do Mestrado Leonilde, Andréia, Camila, Ricardo, Rafael, Andréia Guerra, Liliane, Mitsue e Iara por sempre poder dividir as angústias e alegrias dessa fase.

As minhas amigas Lígia, Débora, Tita, Adriana, Carla, Cecília, Sara, Débora dos Santos e Lisandra pelo incentivo, apoio e alegrias nessa fase.

À todos que colaboraram de qualquer maneira nesse meu aprendizado. 


\section{RESUMO}

Objetivo. Realizou-se avaliação do estado nutricional e do consumo alimentar em operadores de telemarketing submetidos a 3 turnos fixos. Métodos. A amostra foi composta por 218 trabalhadores (Matutino $=72$; Vespertino $=97$ e Noturno $=49$ ) de duas centrais de atendimento telefônico, uma vinculada a planos de saúde (A) e outra a uma empresa aérea (B). Para avaliação antropométrica, foram obtidas as seguintes medidas: peso, estatura e circunferência da cintura (CC). Um questionário para autopreenchimento foi utilizado com os seguintes itens: identificação, hábitos de etilismo e tabagismo, freqüência de consumo alimentar (QFA) de alimentos estimulantes do sistema nervoso central e de lanches. Entrevistas foram realizadas para obtenção de 3 inquéritos recordatórios 24 horas ( 2 dias de trabalho e 1 dia folga). $O$ índice de massa corporal (IMC) (Peso/Estatura ${ }^{2}$ ) e a CC foram classificados de acordo com o preconizado pela Organização Mundial da Saúde (OMS). O cálculo do valor nutricional da dieta (macronutrientes e energia) foi realizado com o auxílio do programa Virtual Nutri. Os testes estatísticos utilizados foram: ANOVA, Kruskal-Wallis, teste exato de Fisher e qui-quadrado de Pearson. Foi considerado nível de significância estatística $\mathrm{p}=0,05$. Resultados. Os operadores eram: 74,2\% do gênero feminino, $44 \%$ tinham curso superior incompleto e com média de idade igual a 28,9 anos (desvio padrão $=7,6$ anos). Do total, 45,0 \% referiram aumentar de peso após começar a trabalhar como operador e $28,9 \%$ alteraram o consumo alimentar devido a ansiedade no trabalho. A obesidade (IMC $\geq 30 \mathrm{~kg} / \mathrm{m}^{2}$ ) atingiu $9,3 \%$ (13,0\% em homens e $8,1 \%$ em mulheres). A CC identificou $14,4 \%$ dos operadores com aumento do risco para doenças crônicas associadas à obesidade ( $\mathrm{CC} \geq 80 \mathrm{~cm}$ para mulheres e $\geq 94$ para homens) e com risco muito aumentado ( $\mathrm{CC} \geq 88 \mathrm{~cm}$ para mulheres e $\geq 102$ para homens) em 11,6\% dos casos. A média do consumo alimentar dos 3 dias evidencia em mulheres, consumo calórico igual a 1612,4 kcal, os valores da porcentagem do valor calórico total da deita (\%VCT) para proteínas de 15,2\%, carboidratos 49,3\% (fibras 10,3 gramas), lipídios $30,6 \%$ (lipídios insaturados 22,8 gramas e colesterol 229,9 gramas). Em homens, o consumo calórico médio foi igual a $2741,7 \mathrm{kcal}$, com valores da \%VCT para proteínas iguais a $16,9 \%$, carboidratos $47,7 \%$ (fibras 14,7 gramas), lipídios 32,9\% (insaturados 41,1 gramas e colesterol 433,9 gramas). Em relação as recomendações da FAO/OMS (1998) para energia a porcentagem de adequação atingiu $77 \%$ para mulheres e $100 \%$ em homens. Baseando-se nas recomendações FAO/OMS (2003) os percentis de lipídios estavam acima e para carboidratos, fibras e lipídios insaturados abaixo do prescrito. Em homens, verificou-se consumo elevado de colesterol e do valor do percentil de proteínas (\%VCT) em relação ao recomendado pela FAO/OMS (2003). O QFA identificou maior consumo de café $(44,5 \%)$ e café com leite $(42,6 \%)$ em relação a substancias estimulantes. Os lanches mais ingeridos diariamente foram: bebidas lácteas $(38,5 \%) \mathrm{e}$ sucos de frutas prontos para beber $(38,1 \%)$. O turno noturno apresentou diferenças significantes em relação à faixa etária, gênero, possuir outro emprego, fumo, IMC em mulheres e consumo de café, refrigerantes a base de cola, refrigerantes, chicletes e balas dietéticas, suco de frutas prontos para beber e salgadinhos e biscoitos. Conclusões. Sugerem-se evidências de dietas não balanceadas e índices elevados do IMC e da obesidade abdominal em operadores de telemarketing em homens do turno noturno. 


\begin{abstract}
Objective. The aim of this survey was to identify nutritional status and food intake among call center operators who work in 3-fixed Schedule. Methods. Two hundred and eighteen workers (Morning=72; Afternoon=97 and Evening= 49) of two call centers were studied (A dealing with health assitence services and B airplane company). For anthropometric assessment were used weight, height and waist circumference (WC). The operators filled self-aplicable questionnaire about identification, smoking and drink habits and food frequency (QFA) of snacks and stimulants consumption. Interviews were taken about dietary intake ( 24 hours recall in 2 workdays and 1 offday). Body mass index (BMI) and WC were classified according to the World Health Organizaton's (WHO) patterns. The nutritional values were calculated through the Virtual Nutri software. The statistics testes were: ANOVA, Kruskal-Wallis, Exact Fisher test and Pearson's chi-square. Statistic significance level was considered less than $\mathrm{p}=0.05$. Results. The operators were: $74.2 \%$ women, $44 \%$ had incomplete undergraduate level and the average age was 28.9 (Std Dev=7.6 years old). In the total, $45 \%$ referred weight gain after start working in call centers and $28.9 \%$ changed dietary habits due to the anxiety during the working time. Obesity (BMI $\geq 30 \mathrm{~kg} / \mathrm{m}^{2}$ ) was $9.3 \%$ ( $13 \%$ in men and $8.1 \%$ in women). WC identified $14.4 \%$ of operators in high risk of chronic diseases associated with obesity (WC $\geq 80 \mathrm{~cm}$ for women and $\geq 94 \mathrm{~cm}$ for men) and in substantially high (WC $\geq 88 \mathrm{~cm}$ for women and $\geq 102 \mathrm{~cm}$ for men) $11,6 \%$ of the cases. The average in 3 days of dietary intake in women showed that caloric intake was $1612.4 \mathrm{kcal}$, the values of percentage of calories (\% VPC) coming from protein was $15.2 \%$ carbohydrates, $49.3 \%$ (fiber 10.3 grams), lipids $30.6 \%$ (unsaturated lipids 22.8 grams and cholesterol 229.9 grams). In men, the caloric intake was $2741.7 \mathrm{kcal}$, with values of \% VPC for protein of $16.9 \%$, carbohydrates $47.7 \%$ (fiber 14.7 grams), lipids $32.9 \%$ (unsaturated lipids 41.4 grams and cholesterol 433.9 grams). Based on FAO/OMS (1998) recommendations of energy, women intakes were $77 \%$ and men $100 \%$ of recommendations. According to FAO/OMS (2003) recommendations, the values of \%VPC for lipids were high and for carbohydrates, fiber and unsaturated lipids were low. In men, cholesterol intake and percentage of protein were high comparing to the FAO/OMS recommendations. The FFQ identified high daily intake of coffee $(44.5 \%)$ and milk with coffee $(42.6 \%)$ based on stimulants consumption. The daily intakes of milky drinks $(38.5 \%)$ and fruit juices ready to drink $(38.1 \%)$ were high. The night shift workers showed significances differences with age, gender, extra job, smoking, BMI in women and intakes of coffee, cola drinks, diet bubblegum and candy, fruit juices ready to drink and cookies. Conclusions. Study findings suggest that diets were inadequate; overall obesity and abdominal obesity were high among call center operators, especially in men that work at night.
\end{abstract}




\section{ÍNDICE}

1) INTRODUÇÃO

1.1) A avaliação do estado nutricional __ 9

1.1.1) Dados bioquímicos _ 10

1.1.2) História e exames clínicos 10

1.1.3) Avaliação do consumo alimentar __ 11

1.1.4) Avaliação antropométrica _ 13

1.2) O Trabalho em turnos e suas implicações nutricionais ___ 15

1.3) O Trabalho dos Operadores de Telemarketing _ 20

2) OBJETIVOS 22

2.1) Objetivo Geral _ 22

2.2) Objetivos Específicos — 22

3) METODOLOGIA

3.1) População _ 23

3.2) Avaliação da situação do trabalho___ 24

3.3) Instrumentos de coleta de dados __ 25

3.3.1) Identificação _ 25

3.3.2) Hábitos de fumo e etilismo 25

3.3.3) Inquérito Nutricional___ 26

3.3.3.1) $O$ inquérito recordatório 24 horas (IR24)_ 26

3.3.3.2) O Questionário de Frequiência Alimentar (QFA) _ _ 27

3.3.3.3) Avaliação antropométrica — 29

3.4) Análise dos dados _ 32

3.5) Aspectos Éticos _ 34

4) RESULTADOS _ 34

4.1) Avaliação da situação de trabalho __ 34

4.1.1) Características das empresas estudadas __ 34

4.1.2.2) Condições de trabalho__ 36 
4.1.2.3) Organização do Trabalho 38

4.2) Características da população estudada 40

4.2.1) Características sócio-demográficas 40

4.2.2) Características quanto ao hábito de fumo e etilismo 42

4.3) Inquérito Nutricional 45

4.3.1) O inquérito recordatório 24 horas 45

4.3.2) O Questionário de Freqüência Alimentar 48

4.3.2.1) Avaliação do consumo de bebidas e alimentos estimulantes do sistema nervoso central (SNC) 48

4.3.2.2) Avaliação do consumo de lanches 50

4.3.3) Características da alimentação servida nas centrais de telemarketing 52

4.3.4) Características dos hábitos alimentares e alteração de peso em operadores de telemarketing 53

4.3.5) Avaliação antropométrica 57

4.4) Situação dos turnos de trabalho nas centrais 60

4.4.1) Características da população em relação aos turnos de trabalho 62

4.4.2) Inquérito nutricional e os turnos de trabalho 65

4.4.2.1) $O$ inquérito recordatório 24 horas 65

4.4.2.2) O questionário de freqüiência alimentar (QFA) 70

4.4.2.3) Avaliação antropométrica 74

5) DISCUSSÃO 79

6) CONCLUSÕES 89

7) REFERÊNCIAS BIBLIOGRÁFICAS 92

1.Anexo - Questionário Aplicado 7

2.Anexo - Termo de consentimento 13

3.Anexo - Parecer do Comitê de Ética 15 


\section{1) INTRODUÇÃO}

Para avaliar o estado nutricional de populações é importante estudar o produto da relação entre consumo alimentar e necessidades nutricionais (VASCONCELLOS 1993). Assim, para melhor entender esses conceitos, é válido realizar uma revisão bibliográfica sobre as principais abordagens do estado nutricional.

Já o estudo sobre operadores de telemarketing requer uma revisão sobre a importância da crescente demanda por esse tipo de serviço e sobre as principais características da profissão. Além disso, como o objeto de estudo é o trabalho em turnos é recomendável citar os trabalhos científicos que indicaram as principais implicações nutricionais que afetariam essa população.

Desta forma, os temas apresentados visam mostrar um panorama geral da avaliação do estado nutricional em operadores de telemarketing submetidos a três turnos fixos de trabalho.

\section{1) A avaliação do estado nutricional}

O conceito de estado nutricional, segundo CHRISTAKIS (1973), é dito como "condição de saúde de um indivíduo, influenciada pelo consumo e utilização de nutrientes, identificada pela correlação de informações obtidas de estudos físicos, bioquímicos, clínicos e dietéticos".

Tendo em mente esse conceito, o estado nutricional pode ser expresso em três diferentes níveis: o estado de normalidade, produto do equilíbrio entre consumo e necessidades nutricionais atendidas; o estado de insuficiência de consumo, produto do consumo qualitativo e/ou quantitativo inferior às necessidades nutricionais e o estado de excesso ou desequilíbrio do consumo, produto do elevado consumo ou desequilíbrio do consumo frente às necessidades nutricionais. Esses três estados nutricionais dependem de fatores que interagem entre si. Esses fatores são: condição sócio-econômica, ambiente emocional, padrão cultural, doenças e comportamento alimentar, que afetariam o consumo de alimentos que, por sua vez, modificariam a ingestão de 
nutrientes. A absorção de nutrientes também pode ser alterada, podendo prejudicar sua utilização e o estado nutricional. Além disso, infecções, doenças, febre ou estresse fisiológico, crescimento, estresse psicofisiológico, manutenção corpórea e bem-estar podem alterar a necessidade de nutrientes para manter um ótimo estado nutricional (VASCONCELLOS 1993; DE HOOG 1998).

Para avaliar o estado nutricional foram desenvolvidas as seguintes abordagens: 1) dados bioquímicos; 2) história e exames clínicos; 3) avaliação do consumo alimentar e 4) avaliação antropométrica (DE HOOG 1998).

\subsection{1) Dados bioquímicos}

É um método que emprega testes laboratoriais de sangue e/ou urina, além de testes cutâneos. O primeiro tem o objetivo de observar a composição do sangue e compará-la com variações normais de hemoglobina, albumina, transferrina, proteínas plasmáticas totais, conteúdo de nitrogênio. Os testes laboratoriais da urina visam avaliar o débito urinário de 24 horas. Os testes cutâneos são úteis para observar imunidade a certas doenças, respostas a antígenos e possível identificação de deficiência de vitaminas e minerais. Ressalta-se que esses testes, em geral, são muito empregados para avaliar as reservas de micronutrientes especificamente (PECKENPAUGH e POLEMAN 1997).

Vale destacar que sua precisão e exatidão variam de acordo com os métodos utilizados. Além disso, não existem testes bioquímicos para avaliar todos os nutrientes, bem como há dúvidas sobre o significado de valores anormais para certos testes. Entretanto, pode-se detectar deficiências ou excessos nutricionais que não são possíveis obter de outras formas (MATAIX VERDÚ e LOPES GONZÁLEZ 1995; DE HOOG 1998).

\subsection{2) História e exames clínicos}

Nos exames clínicos, observa-se perda de gordura subcutânea no tórax, tríceps e perda muscular no quadríceps e deltóides. Presença de edema também pode ser 
observada. Além disso, verifica-se a condição de: pele, cabelo, dentes, gengivas, lábios, língua e olhos. Pode-se utilizar, também, de exames radiográficos para examinar a condição esquelética (PECKENPAUGH e POLEMAN 1997; DE HOOG 1998).

Muitos sinais físicos podem ser resultantes de causas nutricionais ou não nutricionais. Neste caso, é válido utilizar-se de exames bioquímicos para confirmar as suspeitas do exame clínico (DE HOOG 1998).

\subsection{3) Avaliação do consumo alimentar}

O consumo alimentar de uma população pode ser obtido mediante um inquérito alimentar. É caracterizado por uma avaliação quantitativa e qualitativa da alimentação e, segundo MONDINI \& MONTEIRO (1995), sua limitação se deve à dificuldade em captar a grande variabilidade do consumo em um curto período de tempo e ao seu custo elevado se este for prolongado. Vários são os métodos que podem ser empregados para levantamento do consumo, os quais diferem metodologicamente na forma de coleta de dados e tempo de aplicação, como o recordatório 24 horas, diário alimentar, história alimentar, entre outros (VASCONCELLOS 1993; SERRA MAJEM e RIBAS 1995).

A escolha do método depende fundamentalmente dos objetivos, dos nutrientes que se pretende analisar, do tipo de população e dos recursos disponíveis (SERRA MAJEM e RIBAS 1995).

Em estudos epidemiológicos, o inquérito recordatório 24 horas (IR24 horas) e o questionário de frequiência alimentar (QFA) têm sido muito empregados. Desta forma, nesse estudo foram utilizados esses dois instrumentos que serão discutidos a seguir:

\section{Inquérito recordatório 24 horas (IR24)}

O inquérito recordatório 24 horas é uma técnica que pretende estimar o consumo alimentar atual dos indivíduos (GIBSON 1990).

Essa técnica tem sido utilizada em pesquisas populacionais nos Estados Unidos (National Health Nutrition Survey - NHANES I, II e III), Canadá, países da América

Latina e muitos países europeus. É útil em estudos transversais para avaliação de 
médias de consumo populacional. O IR24 não caracteriza a dieta habitual, exceto quando vários IR24 são obtidos (SERRA MAJEM e RIBAS 1995).

Essa técnica consiste em relatar ao entrevistador, treinado na técnica, qual é a quantidade exata de alimentos e bebidas consumidos, incluindo a cocção, as marcas dos alimentos ou preparações ingeridas, os condimentos, gorduras de adição, além de suplementos de vitaminas e minerais, consumidos no dia anterior à entrevista (GIBSON 1990; SERRA MAJEM e RIBAS 1995; BUZZARD 1998).

$\mathrm{O}$ método tem algumas vantagens, entre as quais: é relativamente rápido (a entrevista requer entre 10 e 20 minutos), tem um baixo custo, o entrevistado não precisa ser letrado, conseguem-se maiores detalhes dos dados coletados sobre o consumo alimentar, há boa reprodutibilidade entre os entrevistadores, razoável acurácia entre os dados coletados repetidamente e é um instrumento validado e utilizado em estudos populacionais (BUZZARD 1998; PAO e CYPEL 1997; DWYER 1994). Porém, como o método é, usualmente, aplicado por apenas um dia, podem-se obter dados muito imprecisos da ingestão alimentar; desta forma, recomenda-se a aplicação por mais de um dia (THOMPSON e BYERS 1994; BUZZARD 1998).

\section{Questionário de Freqüência Alimentar (QFA)}

O QFA é um instrumento que apresenta uma lista ou relação de alimentos que se pretende investigar em uma população ou grupo familiar em que se registra a freqüência de consumo desses alimentos em um determinado período de tempo passado. O QFA é útil para descrever a ingestão habitual e atual, ou seja, caracterizar o consumo alimentar de indivíduos e populações em um período de tempo. É muito utilizado, também, em estudos epidemiológicos, principalmente quando se pretende investigar a relação entre dieta e doenças (VASCONCELOS 1993; WILLETT 1998).

O QFA constitui-se de 2 componentes: a lista de alimentos e a freqüência com que os alimentos e preparações são ingeridos. Pode-se incluir, também, o tamanho das porções. São analisados, geralmente, os alimentos que são identificados como fonte de nutrientes na dieta habitual. A lista pode ser composta por alimentos utilizados em outros estudos ou pode-se criar uma nova composição de alimentos. Existem alguns critérios que devem ser recomendados para essa inclusão: a) relativa freqüência pela 
população; b) conteúdo substancial do nutriente que se deseja estudar; c) variação individual. Deve-se lembrar também que a lista deve ser clara, concisa, bem estruturada, organizada de forma sistemática e não conter número excessivo de itens (WILLETT 1998; VASCONCELOS 1993; JIMÉNEZ e MARTÍNS-MORENO 1995).

Quanto à freqüência alimentar, essa dependerá do nutriente que se deseja estudar na população. $\mathrm{O}$ formato deve ser de respostas múltiplas e fechadas. $\mathrm{O}$ ideal é de 5 a 10 opções de freqüência (VASCONCELOS 1993; JIMÉNEZ e MARTÍNS-MORENO 1995; WILLETT 1998).

As porções são úteis quando se utilizam questionários de freqüência semiquantitativos, pois é necessário o tamanho da porção de referência que sirva de guia para estimar o conteúdo de nutrientes. Pode-se utilizar mais de uma porção, pois se tem comprovado que números adicionais de porções auxiliam na validação do questionário. Além disso, a utilização de fotos, modelos bidimensionais e tridimensionais são úteis (VASCONCELOS 1993; JIMÉNEZ e MARTÍNS-MORENO 1995).

O QFA pode conter, ainda, questões sobre a composição da dieta, local de realização das refeições, método usual de preparação dos alimentos, horário das refeições, tipos de alimentos consumidos e uso de suplementos (WHO 1988).

O QFA pode ser aplicado por entrevistadores treinados ou ser autoaplicado; desta última forma, o instrumento se torna mais ágil e econômico (JIMÉNEZ e MARTÍNS-MORENO 1995).

Entre as vantagens do método, estão: aplicação rápida, baixo custo, descrição da dieta habitual, maior utilização quando se pretende investigar um nutriente ou tipos de alimentos específicos, possibilidade de classificar os alimentos quanto à sua freqüência de consumo e obtenção de boa taxa de respostas (PAO e CYPEL 1997; DWYER 1994).

\subsection{4) Avaliação antropométrica}

As medidas antropométricas têm sido utilizadas para verificar o estado nutricional de indivíduos e populações, pois se tem provado que existe grande influência da nutrição sobre as dimensões físicas e composição corporal dos indivíduos. A antropometria avalia as variações das dimensões físicas e da composição corporal do 
corpo humano e, a partir da soma das medidas e exames individuais, obtém-se o estado nutricional de uma população (VASCONCELOS 1993).

Segundo JELIFFE (1968), a antropometria em nutrição "se ocupa da medição das variações nas dimensões físicas e na composição global do corpo humano em diferentes idades e em distintos graus de nutrição".

De todas as medidas antropométricas, o peso e a estatura são as mais utilizadas, mais sensíveis e específicas para avaliar o processo de crescimento e desenvolvimento e, portanto, avaliar o processo saúde e doença. São, também, medidas úteis para verificar o estado nutricional em adultos (VASCONCELOS 1993; DE HOOG 1998).

O peso é a medida antropométrica mais utilizada. Visa quantificar a massa do indivíduo e é importante para verificar se está ocorrendo um crescimento anormal, obesidade ou desnutrição (GORDON et al. 1988).

A estatura é o maior indicador da composição corporal e do comprimento ósseo. É importante para determinar a presença de doença ou desnutrição. Quando relacionada com o peso fornece um bom indicador do estado nutricional do indivíduo (GORDON et al. 1988).

Um índice utilizado para verificar o estado nutricional de indivíduos e populações é o índice de massa corporal (IMC) ou índice de Quetelet. Relaciona o peso (em quilos) com a estatura (em metros). Segundo critérios de classificação preconizados pela Organização Mundial da Saúde (OMS), é possível classificar os indivíduos nas seguintes categorias: desnutrido, normal, sobrepeso e obeso. Essa classificação baseiase na associação entre IMC, mortalidade e morbidade; por exemplo, indivíduos com IMC entre 18,5 e $24,9 \mathrm{~kg} / \mathrm{m}^{2}$ têm menor risco de morbidade e, portanto, de morte precoce. Indivíduos com IMC maior ou igual a 30 são considerados obesos e a obesidade está associada a doenças crônicas degenerativas não transmissíveis, como doença coronariana e diabetes melittus tipo 2 (WHO 1995; DE HOOG 1998; WHO 2000).

Outra medida antropométrica utilizada para verificar o estado nutricional de adultos é a circunferência da cintura. É uma medida com boa correlação com a adiposidade abdominal (WHO 2000). Tem sido empregada para verificar a associação entre distribuição de gordura abdominal e risco para doenças crônicas degenerativas não transmissíveis, como por exemplo, mudanças nos fatores de risco para doença 
cardiovascular e outras formas de doenças crônicas, como o diabetes melittus tipo 2. A circunferência da cintura está associada ao IMC e com à relação cintura/quadril (RCQ). É uma medida fácil de ser tomada e bem simples (CALLAWAY et al. 1988; WHO 2000).

\section{2) O Trabalho em turnos e suas implicações nutricionais}

Trabalhar à noite ou em turnos tornou-se cada vez mais freqüente em muitos tipos de serviços, como alimentação, saúde, segurança, transportes e telecomunicações. A estimativa é que cerca de $20 \%$ dos trabalhadores dos países industrializados estão engajados em algum tipo de trabalho em turnos ou noturnos (US CONGRESS, OFFICE OF TECHONOLOGY ASSESSEMENT 1991).

Diversos fatores são importantes para o aumento do trabalho em turnos: a globalização da economia, o maior crescimento do setor de serviços e o aumento da participação da mulher na força de trabalho. Vale destacar, também, as mudanças demográficas, como aumento da renda familiar resultando em maior demanda nos setores de recreação e entretenimento durante à noite e nos fins de semana, bem como, o aumento da população idosa elevou a demanda por serviços médicos que funcionam 24 horas ao dia (PRESSER 1999; GELIEBTER et al. 2000).

O trabalho em turnos caracteriza-se pela não-interrupção da produção devido à saída do trabalhador do seu posto de trabalho ao término de uma jornada diária, pois outro ocupará o seu lugar (ILO 1977).

Para melhor compreensão do trabalho em turnos, certos conceitos devem ser apresentados:

- Turno: é o período de tempo em que o indivíduo realiza suas funções no trabalho;

- Turno alternante (ou rodiziante): é caracterizado pela contínua modificação dos horários de trabalho, segundo uma escala já determinada. A regularidade dessa escala pode ser: a) regular, na qual há uma escala fixa e esta é repetida a cada ciclo; b) irregular, em que não há uma escala fixa e regular. O horário de trabalho é imprevisível; 
- Fixo (também chamado de turno permanente): aquele em que os indivíduos permanecem trabalhando no mesmo horário, isto é, o trabalhador do período da manhã não trocará de horário com o trabalhador do turno noturno (KNAUTH 1996).

As conseqüências do trabalho em turnos têm sido muito bem averiguadas. $\mathrm{O}$ trabalho em turnos pode alterar os ritmos circadianos ${ }^{1}$, devido a modificações nos osciladores internos (os relógios biológicos), ocorrendo com freqüência distúrbios do sono, doenças gastrointestinais e doenças crônicas degenerativas não transmissíveis. O trabalho em turnos pode, também, modificar as relações sociais. Esse tipo de trabalho pode alterar a estrutura e a estabilidade familiar. Estudos têm comprovado a maior taxa de divórcios entre trabalhadores em turnos, que incluem o turno noturno, do que entre trabalhadores diurnos (MORENO1997; WATERHOUSE et al. 1997; PRESSER 1999). Outro problema social, é que a maioria dos trabalhadores em turnos, sobretudo do turno noturno, faz suas refeições sozinha sem a companhia da família ou do grupo social, pois existe uma incompatibilidade de horários (TEPAS 1990).

Deve-se ressaltar que a dessincronização dos ritmos biológicos pode levar os trabalhadores em turnos a sofrerem alterações no hábito alimentar, levando a problemas físicos, sociais e psicológicos (DUCHON e KERAN 1990; TEPAS 1990).

Quanto às alterações nos hábitos alimentares, o trabalho em turnos pode levar os trabalhadores a consumirem refeições com maiores quantidades de lipídios, especialmente lipídios saturados, menor quantidade de carboidratos complexos, incluindo as fibras, e maior ingestão de sacarose quando comparados com os trabalhadores do turno diurno (HANDJEX 1989; KNUTSSON et al. 1990; LAITINEN 1997).

TURNER (1995), em um estudo transversal realizado em Alberta (Canadá) com dez enfermeiras que trabalhavam em turnos rodiziantes incluindo o turno noturno e a madrugada, verificou alterações na dieta e no sono dessas trabalhadoras. Elas relataram três dias da sua alimentação quanto à quantidade, qualidade e freqüência. A dieta analisada mostrou ter baixo consumo de frutas, verduras e laticínios.

KNUTSSON e cols. (1990) estudaram a dieta de 25 trabalhadores suecos (13 trabalhadores diurnos e $12 \mathrm{em}$ turnos). Os autores avaliaram se a dieta poderia afetar os

\footnotetext{
${ }^{1}$ Evento biológico que se repete regularmente. É resultante da interação entre os osciladores internos e alguns fatores ambientais (MARQUES et al. 1997).
} 
níveis de lipídios séricos. Ao acompanhar o consumo de alimentos por meio de 4 dias de diário alimentar em dois períodos, um antes de começar o trabalho em turnos e outro 6 meses após o início do trabalho (estudo de coorte), a ingestão alimentar foi caracterizada, após 6 meses, como sendo rica em sacarose e com baixa quantidade de fibra dietética. A dieta foi capaz de aumentar o nível de apolipoproteína do tipo B (apo B) alterar a razão apo B e apolipotroteína do tipo A (relacionada com risco para doença cardiovascular). Esse estudo, portanto, sugere que a dieta pode explicar as alterações nos níveis de lipídios plasmáticos.

LENNERNÄS e cols. (1994b) também identificaram alterações nos níveis de lipídios séricos. Nesse estudo transversal, examinou-se o efeito da alimentação (no total foram aplicados 147 vezes o IR24 horas) no estado nutricional (medidos com o auxílio do IMC, da taxa de lipídios e glicose sanguíneos) de 22 trabalhadores suecos que trabalhavam em 3 turnos rodiziantes. Eles verificaram que os trabalhadores do turno da noite alimentavam-se em horários da noite e madrugada, o que elevava a taxa de colesterol total, LDL colesterol ${ }^{2}$ e da razão LDL colesterol/HDL colesterol ${ }^{3}$. Neste caso, ocorreu uma distribuição ao longo das 24 horas do horário das refeições que proporcionou o aumento de lipídios séricos. Além disso, ao correlacionar o consumo de carboidratos com LDL colesterol, identificaram que em $63 \%$ dos casos o aumento de LDL colesterol foi explicado pelo maior consumo de carboidratos à noite. Desta forma, a redistribuição do horário das refeições e a composição da dieta poderiam estar associadas a distúrbios no metabolismo de lipídios.

Os trabalhadores em turnos consumiriam maiores quantidades de carboidratos à noite, segundo REINBERG e cols. (1979), devido à realização de pequenos lanches ricos nesse nutriente, formados por biscoitos, refrigerantes e sanduíches, nos intervalos ao longo do trabalho, diferentemente dos trabalhadores dos outros turnos. Esses autores avaliaram 7 trabalhadores franceses ( 5 em turnos e 2 diurnos) entre 21 e 36 anos em um estudo transversal, utilizando diário alimentar por 8 semanas consecutivas. Identificaram que cerca de $50 \%$ da ingestão de energia dos trabalhadores noturnos foram provenientes do consumo de carboidratos, enquanto nos outros turnos a ingestão foi aproximadamente $40 \%$. Esse comportamento de alimentar-se com pequenas

\footnotetext{
${ }^{2}$ Corresponde a sigla em inglês low density lipoproteins, que significa lipoproteínas de baixa densidade.

${ }^{3}$ Corresponde a sigla em inglês high density lipoproteins, que significa lipoproteínas de alta densidade.
} 
refeições ao longo do turno de trabalho é caracterizado como nibbling, que corresponderia ao ato de "beliscar" diferentes tipos de alimentos, como biscoitos, salgadinhos, sanduíches e refrigerantes.

O comportamento de "beliscar" alimentos pode vir a ocorrer com freqüência pela presença das "máquinas de venda" no local de trabalho. STEWART e WAHLQVIST (1985), em um estudo transversal com trabalhadores dos turnos noturno $(n=87)$, diurno $(n=87)$ e vespertino $(n=95)$ de uma fábrica de combustível australiana, verificaram diferenças significantes no local das refeições entre os trabalhadores do turno vespertino/noturno e diurno. Habitualmente os trabalhadores do turno vespertino/noturno utilizavam-se de alimentos obtidos nessas máquinas ao longo do turno, pois a disponibilidade de comprar alimentos em restaurantes e consumi-los em uma única refeição seria menor.

Outros comportamentos alimentares registrados em trabalhadores em turnos são quanto a ter menor número de refeições e alimentar-se em horários irregulares, o que poderia prejudicar o desempenho, diminuir a concentração e agravar os problemas gastrointestinais relatados pelos próprios trabalhadores em turnos (TEPAS 1990; LAITINEN 1997). As mudanças nos horários das refeições poderiam modificar os ritmos biológicos, pois ocorreriam alterações na atividade enzimática de certos hormônios plasmáticos, como insulina e glucagon, e de certos metabólitos como nitrogênio, corpos cetônicos, NEFA, colesterol e triglicérides, bem como alterariam o esvaziamento gástrico (REINBERG 1983; BOGGILD e KNUTSSON 1999).

Os trabalhadores em turnos, incluindo o turno noturno, também relatam sentir pouco apetite e geralmente não estar satisfeitos com o seu hábito alimentar (TEPAS 1990). Segundo DUCHON e KERAN (1990), a satisfação alimentar estaria relacionada com a mudança constante do número de refeições realizadas por dia e com o hábito de alimentar-se várias vezes ao longo do dia.

Os hábitos alimentares incorretos, as poucas refeições ao longo do dia e as mudanças nos horários das refeições poderiam levar ao ganho de peso excessivo em trabalhadores em turnos, que incluem o turno noturno, quando comparados com os trabalhadores diurnos. Além disso, o aumento da adiposidade em trabalhadores em turnos poderia ocorrer mais rapidamente se esses trabalhadores ingerissem mais calorias nos dias de folga e consumissem lanches após a refeição noturna (ROMON- 
ROUSSEAUX et al. 1985; ROMON et al. 1986; GELIEBTER et al. 2000). Logo, essa população estaria em estado de risco nutricional ${ }^{4}$, devido ao aumento de peso, podendo desenvolver sobrepeso e obesidade. Estudos já têm identificado que trabalhadores em turnos estão em sua maioria com sobrepeso ou são obesos, sobretudo, com obesidade abdominal (HANDJIEX 1989; NIEDHAMMER et al. 1996; NAKAMURA et al. 1997; ALMESVOORT et al. 1999).

Além do estado de risco nutricional em que essa população se encontra, esses trabalhadores freqüentemente sentem-se fatigados, com variações de humor, apresentam sensações de mal-estar e diminuição do alerta, o que os leva, conseqüentemente, a não desenvolverem suas atividades adequadamente (LAVIE 1996; GASPAR et al. 1998).

Uma forma de melhorar o desempenho e promover o alerta, principalmente após as refeições, é a ingestão de substâncias que têm efeitos estimulantes sobre o sistema nervoso central, como o café (TEPAS 1990).

Trabalhadores em turnos, segundo MORENO e cols. (2001), têm aumento do consumo de café em relação aos trabalhadores diurnos. Ao estudar 40 motoristas da região da Grande São Paulo por meio de um QFA, observou-se que 90\% dos motoristas do horário irregular, que incluía o turno noturno, consumiam café puro enquanto no turno diurno $68 \%$. Contudo, outros estudos não comprovaram haver maior consumo de café em trabalhadores em turnos, que incluem o turno noturno (FRESE e HARWICH 1984; ROMON-ROUSSEAUX et al. 1985; TEPAS et al. 1985; LENNERNÄS et al. 1994a).

A ingestão de substâncias estimulantes ocorre porque esses trabalhadores, usualmente, sentem-se mais cansados e têm uma baixa qualidade de sono devido a distúrbios no ciclo vigília-sono ${ }^{5}$ causados por alterações nos ritmos circadianos (FRESE e HARWICH 1984; LAVIE 1996; GASPAR et al. 1998).

Os hábitos alimentares inadequados dos trabalhadores em turnos podem prejudicar a saúde e agravar doenças, pois esses trabalhadores usualmente sofrem de

\footnotetext{
${ }^{4}$ Estado de risco nutricional pode ser descrito como a necessidade fisiológica do indivíduo por nutrientes não estar sendo alcançada, devido a uma ingestão dietética inadequada ou absorção prejudicada ou perda de nutrientes aumentada pelo organismo, levando a alterações fisiológicas que incapacitam o bom funcionamento do organismo, podendo levar à morbidade e, em último caso, à morte (De HOOG 1998).

5 Ciclo vigília-sono: alternância dos estados de sono e vigília de um indivíduo que se repete periodicamente (KLEITMAN 1963).
} 
distúrbios de sono, problemas gastrointestinais e doenças cardiovasculares (TEPAS 1990).

Os problemas gastrointestinais atingem cerca de $20-75 \%$ de trabalhadores em turnos com horário de trabalho que inclui o turno noturno. Sentem, freqüentemente, dispepsia, inchaço, azia, dor abdominal, flatulência e irregularidade intestinal. A presença de úlcera, também, é mais prevalente nesses trabalhadores, além de desenvolverem mais gastrites e gastroenterites crônicas. $\mathrm{O}$ estresse e a fadiga podem contribuir para o aumento dos sintomas gastrointestinais relacionados ao trabalho em turnos (PRESCOTT 1995; COSTA 1996; LAITINEN 1997).

Quanto às doenças cardiovasculares muitos estudos têm avaliado que o trabalho em turnos é um fator de risco para essas doenças. Altos níveis de triglicerídeos e colesterol séricos foram encontrados nessa população. Soma-se a isso alguns estudos que identificaram fatores de risco para doenças cardiovasculres como aumento da pressão arterial, glicose plasmática e obesidade abdominal (HANDJEX 1989; KNUTSSON et al. 1990; ROMON et al. 1992; LENNERNÄS et al. 1994b; NAKAMURA et al. 1997).

\section{3) O Trabalho dos Operadores de Telemarketing}

O segmento de telemarketing tem se expandido de forma expressiva em vários países. O setor cresceu nos últimos 20 anos, tendo um aumento mais acelerado, na ordem de 30\%, nos últimos 5 anos. As estimativas indicam que o setor emprega cerca de 5 milhões de pessoas nos Estados Unidos e aproximadamente 1,5 milhão na Europa (SINTRATEL 2001;TOOMINGAS et al. 2002).

No ano de 2000, foi estimado que $1,0 \%$ a 1,7\% da mão-de-obra do Reino Unido estava trabalhando em centrais de atendimento telefônico, o que representava cerca de 223 mil operadores. Previa-se, então, que essa cifra se elevaria para 274 mil em 2002. No Brasil, o número de profissionais envolvidos no trabalho como operador de telemarketing é estimado em cerca de 284 mil, 120 mil só no Estado de São Paulo (DARBY 2000; SINTRATEL 2001). 
A profissão de telemarketing é caracterizada por atender usuários, oferecer serviços e produtos, prestar serviços técnicos especializados, entre outras atividades. Os meios de trabalho são formados por telefone (headfone monoauricular) e o computador. Os operadores de telemarketing seguem roteiros e scripts pré-determinados com os objetivos de captar, reter e recuperar clientes (SINTRATEL 2001; MATIAS et al. 2002).

Os operadores são caracterizados por estarem compreendidos na faixa etária entre 18 e 30 anos, serem, em sua maioria, do gênero feminino, possuírem escolaridade média ou superior. Além disso, a profissão é caracterizada pela alta rotatividade, aproximadamente metade dos trabalhadores muda de emprego a cada ano (SINTRATEL 2001).

As funções dos operadores de telemarketing, conforme descrição da Classificação Brasileira de Ocupações (CBO), compreendem (SINTRATEL 2001; MATIAS et al. 2002):

- Atuar como operadores de telemarketing ativo e/ou receptivo, atendendo chamadas de clientes;

- Transferir as chamadas para outras pessoas e setores, quando necessário;

- Dar assistência em serviços técnicos e especializados;

- Realizar vendas de bens e produtos;

- Receber reclamações e fornecer informações para os usuários da empresa;

- Fazer ligações para venda de produtos e serviços;

- Realizar retenção;

- Cobrar débitos;

- Fazer pesquisas via telefone e cuidar do cadastramento de clientes;

- Realizar notificações aos clientes da empresa.

Para desempenharem essas funções é necessário que os operadores possuam boa fluência verbal, postura profissional e alguma experiência na área ou pelo menos boas noções de informática (SINTRATEL 2001).

As atividades de telemarketing funcionam em centrais que, usualmente, trabalham durante as 24 horas do dia e, geralmente, esses trabalhadores possuem jornada de trabalho de seis horas com diversos horários que incluem manhã, tarde, noite 
e madrugada, podendo haver, ainda, turnos de trabalho rodiziantes e horários de trabalhos irregulares (MATIAS et al. 2002).

São ainda pouco estudados os efeitos potenciais dessa atividade sobre a saúde dos trabalhadores e, não existem estudos sobre as condições do estado nutricional em operadores de telemarketing que trabalham em turnos.

\section{2) OBJETIVOS}

\section{1) Objetivo Geral}

Este estudo visa avaliar o estado nutricional e o consumo alimentar de operadores de telemarketing de duas centrais de atendimento telefônico no município de São Paulo - SP, submetidos a 3 turnos fixos de trabalho.

\section{2) Objetivos Específicos}

Avaliar a situação do trabalho dos operadores de telemarketing, quanto aos aspectos de condições físicas e organização do trabalho.

Caracterizar o consumo alimentar dos operadores de telemarketing.

Avaliar por meio da avaliação antropométrica o estado nutricional dos operadores de telemarketing.

Comparar o consumo alimentar e o estado nutricional dos operadores de telemarketing que trabalham em três turnos fixos, incluindo matutino, vespertino e noturno. 


\section{3) METODOLOGIA}

\section{1) População}

O estudo foi realizado com 218 trabalhadores de duas centrais de atendimento telefônico de empresas de ramos de atividades econômicas distintas. Uma empresa (A) atuava na área de planos de saúde e a outra (B) atendia clientes de uma companhia aérea, sendo que ambas localizavam-se na cidade de São Paulo - SP.

A Central A contava com 42 posições de atendimento e cerca de 200 funcionários. Cento e quinze operadores faziam o atendimento das chamadas, esses estavam distribuídos da seguinte forma: turnos matutino e vespertino, 46 operadores cada; turno noturno, 17 operadores; turno da madrugada, 6 operadores. A central B contava com um total de 405 funcionários, dos quais 351 eram operadores. Os operadores do turno da manhã eram 186; os da tarde 124; e os da noite 41.

Do total de operadores das empresas, foi definida uma amostra de operadores de telemarketing de acordo com o turno de trabalho e com a análise estatística que foi aplicada (teste de uma média populacional com um desvio padrão desconhecido, utilizando os valores de $\beta=20 \%$ e $\alpha=5 \%$ e $d=0,5$ para um teste bicaudal) recomendandose utilizar 70 indivíduos (n) (35 em cada empresa) de acordo com o turno de trabalho, totalizando 210 operadores (BERQUÓ et al. 1980).

Desta forma, foram convidados todos os indivíduos que trabalhavam nos seguintes horários: 6:00-12:00 horas e 7:00-13:00 horas (período matutino); 12:0018:00 horas e 13:00-19:00 horas (período vespertino); 18:00-00:00 horas e 19:00-01:00 hora (período noturno). $\mathrm{Na}$ empresa $\mathrm{A}$, como o número de indivíduos nesses horários era insuficiente em relação ao critério referido acima, incluiu-se o horário das 8:0014:00 horas (período matutino) e 14:00-20:00 horas (período vespertino).

Em relação ao total de operadores em cada turno, dos 232 e 170 operadores do turno matutino e vespertino participaram $72(31,0 \%)$ e $97(57 \%)$, respectivamente. No turno noturno, havia 50 trabalhadores, sendo que 49 (98\%) responderam à pesquisa. 
Do total de operadores participaram do estudo, 72 (33\%) pertenciam ao turno matutino, $97(44,5 \%)$ ao turno vespertino e $49(22,5 \%)$ ao turno noturno, totalizando 218 operadores.

\section{2) Avaliação da situação do trabalho}

De agosto a novembro de 2001, foi realizada pesquisa exploratória do ambiente de trabalho, com visitas semanais às duas centrais de atendimento que constou das seguintes etapas:

- Entrevistas individuais com representantes da administração e operadores de telemarketing que ocupavam cargos em diferentes setores;

- Observação dos trabalhadores em diferentes núcleos e turnos de trabalho.

As entrevistas eram formadas pelos seguintes assuntos: o tempo de trabalho na empresa, as funções desempenhadas na central antes de ocupar o atual cargo, as tarefas da atual função e as facilidades e dificuldades do trabalho como operador de telemarketing. Essas abordagens visavam dar um panorama geral da empresa em que trabalhavam e das tarefas desenvolvidas. As entrevistas duravam cerca de duas horas e as respostas dos operadores eram anotadas para posterior descrição.

A observação dos operadores nos diferentes núcleos e turnos constituía da verificação das condições de trabalho, ou seja, identificar o conteúdo das tarefas, a carga mental, o controle sobre o trabalho, o ritmo de trabalho e o ambiente físico do trabalho. Foram realizados, nessa etapa, também filmagens e fotos com o intuito de averiguar as condições físicas do local de trabalho, isto é, observar o ambiente físico como posto de atendimento, iluminação, ventilação, acústica, conforto térmico, bem como observar o desenvolvimento das tarefas. Essa etapa durou cerca de 6 horas em cada central, totalizando 12 horas.

A escuta das ligações atendidas pelos operadores durava cerca de 1 hora e eram verificadas as demandas desse tipo de serviço. Primeiramente, o operador autorizava a escuta da ligação telefônica e posteriormente eram averiguadas as ligações que chegavam às centrais. No total, foram realizadas 6 escutas (três em cada empresa) durando cerca de 6 horas nos diferentes turnos. 
A partir desses dados foi possível caracterizar a situação de trabalho, que é definida como a somatória dos aspectos das condições de trabalho e a forma de organização do trabalho (FIALHO e SANTOS 1997).

\section{3) Instrumentos de coleta de dados}

\subsection{1) Identificação}

Os indivíduos responderam, nas centrais de telefonia das duas empresas, às questões referentes à sua identificação: sexo, idade, estado marital, presença ou não de filhos, quantidade de filhos, horário de trabalho, segundo emprego, horário do segundo emprego, escolaridade, estudos atual e horário do estudo (ANEXO 1).

\subsection{2) Hábitos de fumo e etilismo}

Foram avaliados os estilos de vida dos operadores quanto ao fumo, ingestão de bebidas alcoólicas e uso de medicamentos para manter-se acordado ou dormindo.

O hábito de fumar foi avaliado quanto a: fumar mais de 20 maços de cigarros em toda a sua vida, tempo que fuma/fumava, freqüência e tempo que parou de fumar (RODRIGUES e RUFFINO NETTO 1991).

O consumo de bebidas alcoólicas foi questionado quanto a: prática do hábito, freqüência do consumo e o tipo de bebida. Os medicamentos para manter-se acordado ou dormindo foram avaliados quanto ao seu uso. 


\subsection{3) Inquérito Nutricional}

Foi utilizado inquérito nutricional constando das seguintes etapas: inquérito recordatório de consumo alimentar de 24 horas (IR24), questionário de frequiência de consumo de alimentos e avaliação antropométrica.

\subsubsection{1) O inquérito recordatório 24 horas (IR24)}

Foram obtidos 3 inquéritos recordatórios 24 horas pela pesquisadora (um dia de folga e dois dias de trabalho).

Primeiramente, ocorreu o treinamento na técnica do IR24, utilizando-se de entrevistas já gravadas realizadas por outra nutricionista e a utilização dessa técnica em outra pesquisa (MORENO et al. 2001). Além disso, o instrumento foi testado com os operadores de telemarketing.

A entrevista constituía em relatar à pesquisadora todos os alimentos, bebidas e preparações ingeridas no dia anterior ao dia da entrevista, bem como sua quantidade e detalhes quanto ao tipo de condimentos, gorduras utilizadas, uso de adoçantes etc. $\mathrm{O}$ IR24 iniciava-se com o operador descrevendo os alimentos consumidos pela manhã, depois os ingeridos à tarde e, por último, os da noite. Era obtida também a informação sobre o horário e local das refeições. A pesquisadora tentou ter uma atitude neutra na condução da entrevista.

Os entrevistados relatavam a quantidade dos alimentos, bebidas e preparações ingerida em medidas caseiras. Foram utilizadas fotografias (ZABOTTO et al. 1996) das porções dos alimentos e de utensílios domésticos para auxiliar os indivíduos na descrição da porção consumida. Os operadores procediam da seguinte maneira: eles identificavam, através das fotografias, a porção consumida e a entrevistadora anotava a porção referida. Por exemplo, se o operador dizia ter se alimentado de arroz branco cozido, e não sabia dizer o tamanho da porção, era utilizado o álbum de fotos. Desta forma, eram mostradas as porções que se referiam ao arroz branco, o entrevistado apontava a de provável consumo, que era anotada em seu IR24 horas. As entrevistas duravam cerca de 10 a 15 minutos para sua execução. 
A partir das informações dos recordatórios, analisou-se a média dos 3 dias de consumo alimentar quanto a calorias totais (kcal), macronutrientes totais (em gramas), porcentagem de lipídios, proteínas e carboidratos em relação ao valor calórico total (\%VCT) da dieta, colesterol (em miligramas), lipídios insaturados e fibra total (em gramas).

\subsubsection{2) O Questionário de Freqüiência Alimentar (QFA)}

Nesse estudo, foi utilizado um questionário de freqüência alimentar para estimar o consumo de substâncias estimulantes, como café, guaraná, chá preto e mate, e de "lanches", definidos como alimentos e preparações ingeridos entre as refeições principais, que compreendiam salgadinhos, biscoitos, sanduíches, salgados, sucos, bebidas lácteas, frutas e doces. O modelo do questionário foi utilizado por MORENO e cols. (2001) para avaliar a freqüência de substâncias estimulantes do sistema nervoso central em motoristas de caminhão que trabalhavam em horários irregulares. Para verificar se o questionário era de fácil compreensão, esse foi pré-testado para essa população com 2 operadores da empresa B e com 12 da empresa A. Os resultados da média do consumo diário evidenciaram, para substâncias estimulantes, maior ingestão de achocolatado e para lanches, bebidas lácteas. Não foi possível validar e reproduzir o instrumento.

O QFA foi formado por uma lista de 26 alimentos, divididos em 10 alimentos estimulantes do sistema nervoso central e 16 alimentos que são usualmente utilizados para fazer pequenos lanches. Os alimentos estimulantes foram selecionados de acordo com o estudo de MORENO e cols. 2001. Os critérios utilizados para incluir os lanches foram: poder adquiri-los em "máquinas de venda" ou restaurante e lanchonete das centrais, aceitabilidade pela população em geral, poder ser trazido ao local de trabalho e ser, usualmente, utilizado para tomar um lanche.

Os alimentos estimulantes eram formados por: refrigerante à base de cola, refrigerante à base de guaraná, chá preto, chá mate, outro tipo de chá, café, café com leite, achocolatado, chocolate em barra e guaraná em pó. Os lanches eram compostos pelos seguintes alimentos, bebidas e preparações: refrigerante dietético (diet), outro tipo de refrigerante, salgadinhos (batata frita, baconzitos etc.), biscoito ou bolacha, fruta, 
sanduíches (hambúrguer, cachorro-quente, cheeseburguer etc), doce, salgado (coxinha, esfiha etc), bala, bala dietética (diet), chicletes, chicletes dietéticos (diet), barra de cereais, vitamina pronta para beber, suco de fruta pronto para beber e pão com manteiga. Foram também incluídos: café com leite, refrigerante à base de cola, refrigerante à base de guaraná, chocolate em barra, leite com achocolatado e café com leite, uma vez que podiam ser consumidos como lanches.

A freqüência variou entre "nunca consome" até "consumo diário" (as alternativas eram: não, duas vezes ao mês, mensal, semanal, diário). O indivíduo respondia, também, ao número de vezes que repetia essa freqüência. Por exemplo, identificava que consumia tal alimento diariamente e indicava quantas vezes ao dia que reproduzia essa freqüência. Quanto às porções dos alimentos, os operadores informavam a quantidade de porções ingeridas a partir de uma porção padrão (média). Foram utilizadas fotos para auxiliar os operadores na estimativa do tamanho da porção, que eram usadas da seguinte forma: eram mostrados aos indivíduos os tamanhos das porções referidas no questionário com o auxílio do álbum de fotos e esses identificavam a porção mais consumida anotando no questionário (ZABOTTO et al. 1996). O tempo de aplicação do instrumento foi de cerca de 25 minutos.

O questionário constou de 12 questões referentes ao hábito alimentar e quanto à relação entre estado nutricional, ser operador de telemarketing e turnos de trabalho. As questões incluíram os seguintes temas: número (de uma a seis refeições por dia ou muda com freqüência), horário (sempre, às vezes ou nunca no mesmo horário) e quais refeições (café da manhã, lanche da manhã, almoço, lanche da tarde, jantar e lanche da noite) eram consumidas por dia; alteração do peso em relação à profissão de operador; variação de peso em relação ao turno de trabalho; relação entre trabalho e alteração de peso; modificação da alimentação no último mês e tempo dessa alteração; ganho ou perda recente de peso; ganho de peso na vida adulta e a relação entre ansiedade e modificação do consumo alimentar. 


\subsubsection{3) Avaliação antropométrica}

As medidas foram coletadas três vezes utilizando a média do peso e estatura para cálculo do IMC e comparação com o padrão preconizado pela Organização Mundial da Saúde (OMS). A média da circunferência da cintura foi classificada de acordo com a indicada pela OMS. Gastaram-se, aproximadamente, 10 minutos para realizar tais medidas.

Peso

Para obter o peso dos operadores de telemarketing foi utilizada a balança da marca Tanita ${ }^{\circledR}$ com bateria solar (precisão de $200 \mathrm{~g}$ ). Os operadores ficaram em pé no centro da balança com todo o peso apoiado sobre os pés. O pesquisador ficou ao lado da balança para verificar se os pés estavam no centro da balança e, posteriormente, foi realizada a medição. Foi estipulado que os operadores vestiriam apenas roupas leves, excluindo sapatos, casacos e blusas de lã (GORDON et al. 1988; FRISANCHO 1990).

\section{Estatura}

A estatura foi medida utilizando-se do estadiômetro (precisão de $0,1 \mathrm{~cm}$ ) para todos os operadores. O estadiômetro é um instrumento formado por uma fita métrica anexada a uma haste horizontal que é encostada no maior ponto superior da cabeça.

Para se obter a estatura, o indivíduo, primeiramente, tirava seu calçado. $\mathrm{O}$ aparelho era fixado adequadamente a 2 metros do chão a uma parede sem rodapé e o trabalhador ficava embaixo do mesmo formando um ângulo reto com esse. O operador ficava na posição ereta com os calcanhares juntos e as costas retas conforme fosse possível. Os calcanhares, as nádegas, os ombros e a parte posterior do crânio ficavam encostados na parede. Os braços ficavam ao longo do corpo com as palmas voltadas para dentro e os joelhos ficavam juntos em paralelo com a parede. O peso do indivíduo, desta forma, ficava distribuído sobre os pés e a cabeça era posicionada no plano 
horizontal de "Frankfurt" posição até o aparelho ser trazido ao ponto superior da sua cabeça, fazendo suficiente pressão para comprimir o cabelo. Posteriormente, era realizada a medição na escala do aparelho e anotava-se a sua estatura no questionário. Essa medida foi realizada 3 vezes (GORDON et al. 1988; FRISANCHO 1990).

\section{Circunferência da cintura}

A técnica aplicada foi a seguinte: o indivíduo vestiu roupas leves, ficou ereto com o abdômen relaxado, os braços ao lado do corpo e os pés juntos. A fita inelástica foi corretamente posicionada em plano horizontal em paralelo com os quadris, na menor parte do dorso. O pesquisador ficou ao lado do indivíduo próximo à fita para realizar a medida. A medição foi realizada no final de uma expiração sem a fita comprimir a pele entre a crista ilíaca e a costela. A precisão da fita foi de $0,1 \mathrm{~cm}$. A medida foi realizada 3 vezes e foi calculada a média de cada indivíduo (CALLAWAY et al. 1988).

A partir da execução das medidas obtidas foram calculados os seguintes índices e indicadores antropométricos para avaliação do estado nutricional:

\section{Índice de Massa Corporal (IMC)}

É definido como o peso (em quilogramas) dividido pela estatura (em metros) ao quadrado, conforme é mostrado a seguir (WHO 1995):

$$
\text { IMC }=\frac{\text { Peso }}{\text { Estatura }}{ }^{2}
$$

Para classificação do IMC, foram adotados os seguintes indicadores preconizados pela OMS (Tabela 1).

\footnotetext{
${ }^{6}$ Plano Horizontal de Frankfurt é um termo utilizado para descrever quando a cabeça do indivíduo fica ereta e o olhar fixo em um ponto paralelo ao chão (CALLAWAY et al. 1988).
} 
Tabela 1 - Classificação do IMC para adultos

\begin{tabular}{cc}
\hline Classificação & IMC $\left(\mathbf{k g} / \mathbf{m}^{2}\right)$ \\
\hline Desnutrido & $<18.5$ \\
Normal ou Eutrófico & $18.5-24.99$ \\
Excesso de peso & $\geq 25.00$ \\
Sobrepeso & $25.00-29.99$ \\
Obeso classe I & $30.00-34.99$ \\
Obeso classe II & $35.00-39.99$ \\
Obeso classe III & $\geq 40.00$ \\
\hline Fonte: World Health Organization (WHO), Geneva, 1995.
\end{tabular}

Fonte: World Health Organization (WHO), Geneva, 1995.

Indicador da Circunferência da Cintura (WHO 2000)

Nesse estudo, a partir dos dados das 3 medidas da circunferência da cintura, foi calculada a sua média e o valor encontrado foi classificado com o padrão de referência da Organização Mundial da Saúde (OMS). Esse padrão, dividido segundo o gênero, visa classificar os indivíduos com risco para doenças metabólicas associadas ao depósito abdominal de gordura. Os indivíduos podem ser classificados em: risco aumentado para complicações metabólicas e risco muito aumentado para essas doenças crônicas não transmissíveis associadas à obesidade, conforme é descrito na tabela 2 (WHO 2000). 
Tabela 2 - Pontos de corte da circunferência da cintura, segundo gênero, associado com complicações metabólicas da obesidade.

\begin{tabular}{|c|c|c|}
\hline \multirow[t]{2}{*}{ Risco de complicações metabólicas } & \multicolumn{2}{|c|}{ Circunferência da cintura $(\mathrm{cm})$} \\
\hline & Masculino & Feminino \\
\hline Aumentado & $\geq 94$ & $\geq 80$ \\
\hline Muito aumento & $\geq 102$ & $\geq 88$ \\
\hline
\end{tabular}

Fonte: World Health Organization (WHO), Geneva, 2000.

\section{4) Análise dos dados}

Foi realizada análise descritiva das características das empresas e das situações de trabalho com os dados obtidos na observação dos operadores nos diferentes núcleos, das entrevistas e, das fotos e filmagens.

As características gerais dos trabalhadores, os hábitos de etilismo e tabagismo, os hábitos alimentares e alteração de peso em operadores de telemarketing foram descritos em freqüências.

O consumo de medicamentos para manter-se acordado e dormindo foram analisados, apenas se consumia ou não consumia. As demais questões (freqüência e qual medicamento ingeria) não foram analisadas, pois o número de indivíduos que respondeu que consumia medicamentos foi pequeno.

Os dados do consumo alimentar foram analisados com o auxílio do programa Virtual Nutri (PHILIPPI et al. 1996). A partir deste procedimento realizou-se média do consumo dos 3 dias analisados. Alguns alimentos e preparações foram substituídos por similares, pois não foi possível obter a informação nutricional de tais produtos. Além disso, quando os operadores consumiam preparações de que não era possível obter a receita, por exemplo, quando se alimentavam em um restaurante, utilizaram-se receitas similares à descrita por esses. Esses dados, divididos por gênero, foram comparados com a recomendação de macronutrientes preconizada pela WORLD HEALTH ORGANIZATION (WHO)/FOOD AND AGRICULTURE ORGANIZATION (FAO) (2003) para energia e proteínas por quilograma de peso corpóreo o da ORGANIZAÇÃO 
MUNDIAL DA SAÚDE (OMS)/ORGANIZAÇÃO DE ALIMENTOS E AGRICULTURA DAS NAÇÕES UNIDAS (FAO)/ORGANIZAÇÃO DAS NAÇÕES UNIDAS (ONU) (1998).

Os alimentos e bebidas do QFA foram analisados nas categorias: substâncias estimulantes do sistema nervoso central e lanches. Na categoria lanches, agruparam-se os alimentos e bebidas por semelhança da composição nutricional do produto e sua forma física (líquida ou sólida). Desta forma, foram formadas as seguintes categorias: refrigerantes (formada por outros refrigerantes e bebida à base de cola e guaraná), refrigerantes dietéticos, bebidas lácteas (café com leite, leite com achocolatado e vitamina pronta para beber), biscoitos/salgadinhos, frutas/barra de cereais, bala/chiclete dietético, doces (chocolate em barra, chiclete e bala), suco de frutas pronto para beber e sanduíches/salgados (sanduíches, salgados e pão com manteiga).

Os dados do peso e da estatura foram analisados pela média e desvio-padrão divididos por gênero e turnos de trabalho. $\mathrm{O}$ IMC e $\mathrm{CC}$ foram analisados descritivamente em freqüências. Os dados do IMC divididos por faixa etária, gênero e turnos de trabalho foram comparados com a Pesquisa Nacional sobre Saúde e Nutrição (PNSN) (COITINHO et al. 1989).

As análises estatísticas em relação ao turno de trabalho foram realizadas com as seguintes variáveis: faixa etária, gênero, estado civil, número de filhos, escolaridade, possuir outro emprego, ser estudante, fumar, quantidade de cigarros fumados ao dia, consumir bebida alcoólica, tipo de bebidas alcóolicas consumidas, freqüência de consumo de bebidas alcóolicas, consumo quanto a calorias, proteínas, carboidratos, lipídios, colesterol, lipídios insaturados, fibras, substâncias estimulantes, lanches e porcentagem de proteínas, carboidratos e lipídios em relação às calorias totais da dieta (\%VCT), bem como peso, estatura, IMC e CC.

Foi considerada significância estatística o teste que apresentasse nível de significância menor que $0,05(\mathrm{p}<0,05)$.

Foram utilizados os seguintes programas para a análise dos dados:

1) Excel $^{\circledR:}\left(\right.$ MICROSOFT $\left.{ }^{\circledR} 2000\right)$ : para tabulação dos dados;

2) Stata (Stata coporation 2000): para análise descritiva e estatística dos dados (teste exato de Fisher, teste qui-quadrado de Pearson, Análise de Variância - ANOVA e teste Kruskal-Wallis). 


\section{5) Aspectos Éticos}

Nos procedimentos que foram realizados, ou seja, entrevistas e medições, foi apresentado o Termo de Consentimento (ANEXO 2) aos trabalhadores contendo os objetivos da pesquisa, destacando o caráter voluntário e anônimo da participação, o sigilo das informações coletadas e a possibilidade de obtenção de maiores informações com a coordenação da pesquisa.

O Projeto de Mestrado foi aprovado na 072/01 Sessão Ordinária (04/06/2001) do Comitê de Ética em Pesquisa da Faculdade de Saúde Pública da Universidade de São Paulo (COEP) (ANEXO 3).

\section{4) RESULTADOS}

\section{1) Avaliação da situação de trabalho}

\subsection{1) Características das empresas estudadas}

A empresa A prestava serviços de assistência à saúde aos funcionários, familiares e ex-funcionários de um banco estatal, administrando planos próprios ou contratando planos de assistência à saúde. A empresa disponibilizava o plano saúde família, voltado para os familiares dos funcionários. A central de telemarketing tinha como objetivos:

- Fornecer informações e orientação aos usuários sobre os planos de saúde;

- Conceder autorizações prévias ("senhas prévias”) para a realização de procedimentos médico-hospitalares e laboratoriais;

- Esclarecer normas e funcionamento da empresa;

- Realizar atualização cadastral;

- Regularizar as mensalidades;

- Acolher críticas e sugestões; 
- Fornecer informações sobre a rede de credenciados, situação de pagamento e prazos de carência.

A Central funcionava ao longo das 24 horas do dia, operando com turnos de trabalho que incluíam: manhã, tarde, noite e madrugada. O serviço ocorria também aos sábados, domingos e feriados. Recebia uma média de aproximadamente 120 mil ligações por mês, cujo volume era maior às segundas e terças-feiras e no início do mês, sendo os horários de pico entre 9:00h e 11:30h e entre 15:00h e 18:00h. O número de ligações sofria acentuada redução nos meses de férias escolares.

A empresa B prestava serviços a clientes de uma companhia aérea brasileira. Era formada por três holdings que detinham ações de diferentes empresas de serviços de transporte aéreo, bem como empresas do ramo de hotelaria, empresas de fretamento de vôos e de prestação de serviços. A Central de São Paulo fazia reservas para todo o Brasil, tendo incorporado, ao longo dos dois anos anteriores à pesquisa, os serviços antes realizados por centrais existentes em vários estados. Essa central oferecia suporte quanto a:

- Informações sobre o preço das tarifas;

- Obtenção de passagens aéreas;

- Realização de reservas de vôos;

- Recebimento de reclamações e sugestões.

A Central funcionava durante 24 horas, inclusive fins de semana e feriados, em turnos variáveis de trabalho, distribuídos entre manhã, tarde, noite e madrugada. O volume de ligações na central era de cerca de 18 mil chamadas por dia, chegando a atender às segundas-feiras cerca de 20 mil chamadas. $\mathrm{O}$ total esperado diariamente era de 16 mil ligações. Aos sábados e domingos o número de ligações girava em torno de 8 a 9 mil. Os horários de pico de ligações eram das 9:00 às 12:00 horas da manhã e entre 14:00 e 15:00 horas. O período que antecedia férias escolares tinha maior volume de ligações que outros períodos do ano. 


\subsection{2) Condições de trabalho}

Os operadores de telemarketing desenvolviam suas atividades em ambiente fechado nas centrais de atendimento ou centrais telefônicas. A central A possuía um salão destinado ao atendimento e outro para o setor administrativo. A Central B possuía um salão destinado aos setores de anomalias, off-line e PTA (Passagem de Transporte Aéreo) e o outro era utilizado para o atendimento.

O operador de telemarketing realizava as suas tarefas no Posto de Atendimento (PA). Esse era formado basicamente pelo telefone, computador, mesa e cadeira. O operador, normalmente, trabalhava sentado com movimentos basicamente dos braços, mãos e do aparelho fonador. Os PAs nem sempre eram adequados ao trabalho, como na central A e em um dos salões da B, pois as bancadas de trabalho tinham pouca profundidade, impedindo que os monitores fossem colocados à frente do operador. Com isso, o operador era obrigado a trabalhar "de lado", com o teclado à sua frente e a cabeça torcida no sentido do monitor, além de precisar manter o braço esticado para movimentar o mouse. As cadeiras nem sempre eram ajustadas à estatura do trabalhador e havia ausência de suporte para os pés.

Figura 1 - Posto de Atendimento (PA) em uma das centrais de atendimento.

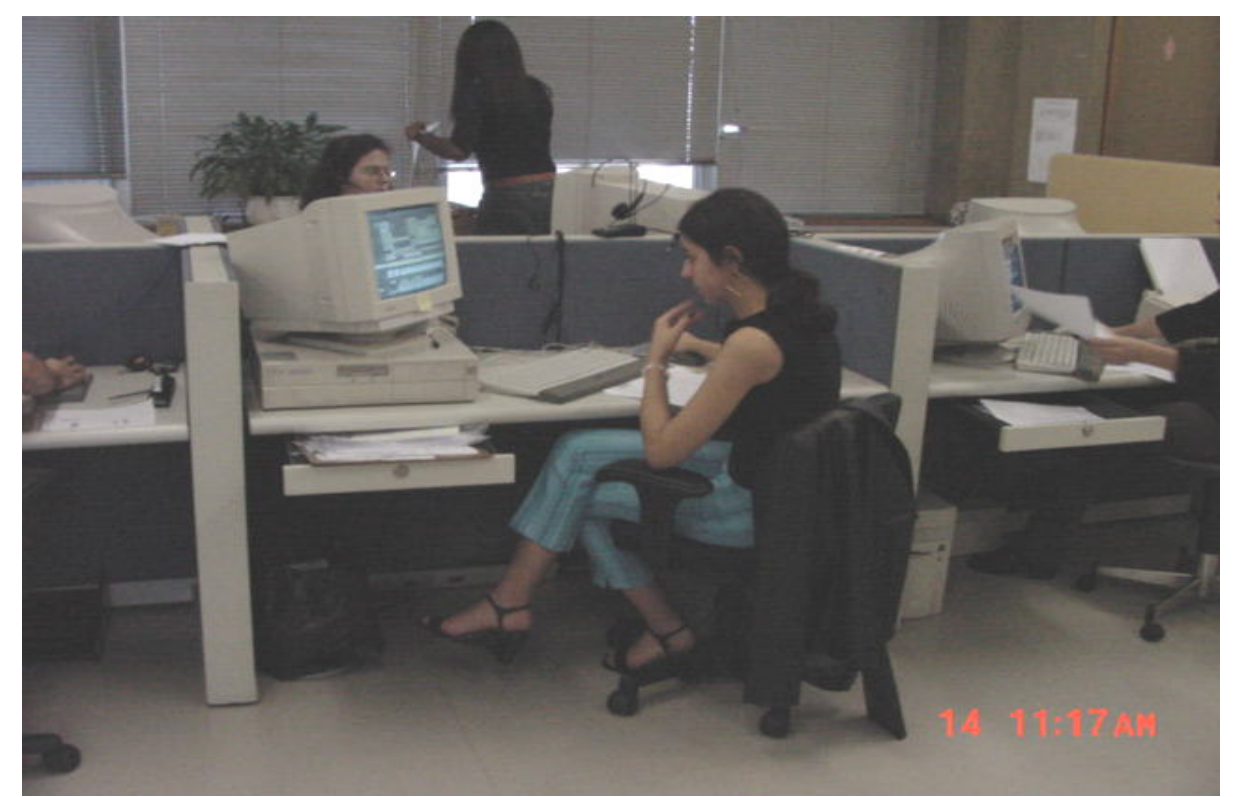


Na central A, os servidores ${ }^{7}$ utilizados até o início da pesquisa não permitia um fluxo adequado de trabalho, representando grande lentidão na movimentação de telas. A aquisição de novo servidor reduziu o tempo de espera para a mudança de telas e o sistema passou a operar com mais rapidez, aumentando a produtividade. Os trabalhadores referiram que essa maior produtividade significou maior cansaço no trabalho pelo fato de atender várias ligações em sequiência sem pausas para poder "respirar". Queixas também foram referidas quanto à qualidade dos headsets e dos amplificadores (aparelho compacto que é conectado ao telefone e ao headset e usado para atender as ligações) utilizados no serviço.

As condições acústicas das centrais dificultavam a realização das tarefas, devido ao ruído ambiental produzido pela fala simultânea e constante de operadores e supervisores. Não havia revestimento acústico no ambiente da central A. Em um dos salões da central $\mathrm{B}$, o salão de atendimento tinha tratamento acústico e o ruído produzido no local não era desagradável.

Os salões dispunham de aparelhos de ar condicionado em número suficiente e de janelas de vidro com abertura ampla. A iluminação do ambiente nas centrais era direta, provocando reflexos no terminal de vídeo dos operadores. Contudo, em um dos salões da central B, foram verificadas instalações que não permitiam luz direta nos monitores de vídeo.

\footnotetext{
${ }^{7}$ Computador que compartilha dados e serviços entre usuários de uma rede (HOUSSAIS e SALLES 2001).
} 
Figura 2 - Foto do ambiente de trabalho em uma das centrais de atendimento.

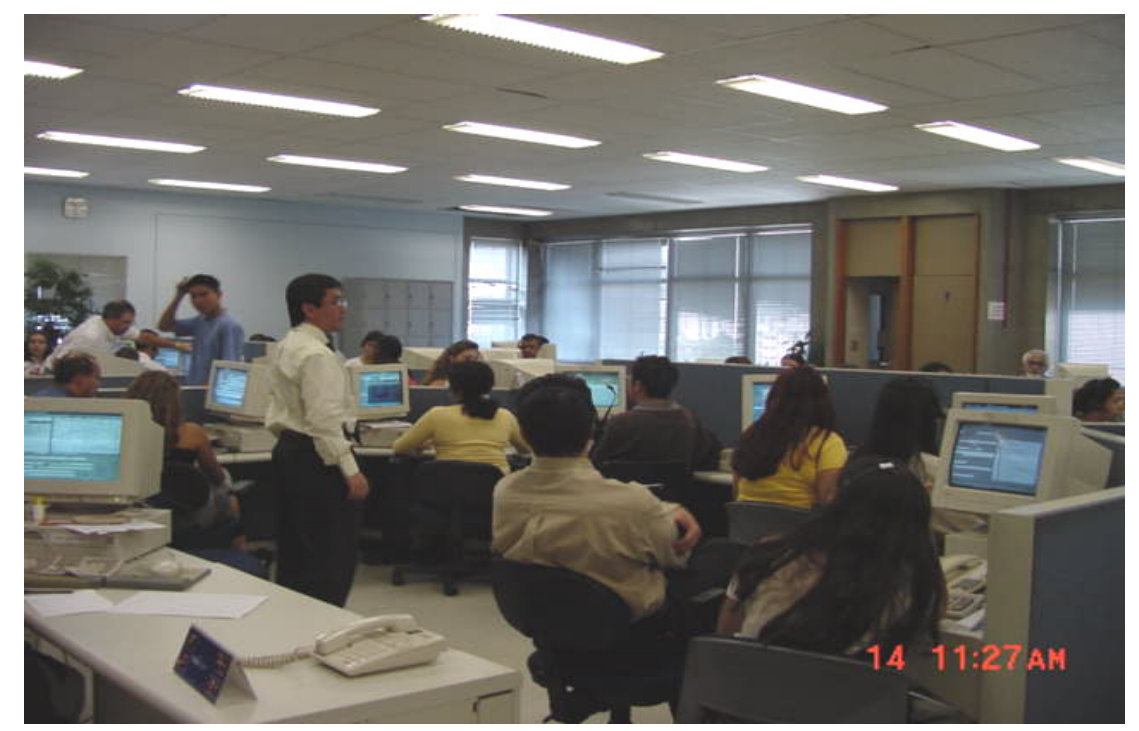

\subsection{3) Organização do Trabalho}

Os aspectos que foram considerados na organização do trabalho dizem respeito a: conteúdo da tarefa, carga mental, controle sobre o trabalho e ritmo do trabalho.

Quanto ao conteúdo das tarefas, os operadores, em ambas as empresas, desempenhavam as seguintes funções:

- Atendimento de chamadas;

- Transferência de chamadas para outras pessoas e setores quando necessário;

- Realização de vendas de bens e produtos;

- Recebimento de reclamações e fornecimento de informações para os usuários das empresas;

- Realização de notificações aos clientes da empresa.

Além disso, os operadores, nas duas centrais, atendiam ligações de todo o Brasil, recebendo e passando informações para uma grande diversidade de clientes.

A central de atendimento A contava com médicos e operadores de telemarketing. Os operadores eram divididos em seniores, plenos e juniores. Os seniores respondiam pela supervisão, orientação e qualidade das equipes de operadores. Os plenos 
auxiliavam e substituíam os operadores seniores, atuavam em treinamentos auxiliando novos operadores e prestavam orientações aos usuários do plano. As atividades dos operadores juniores variavam de acordo com o módulo em que trabalhavam, ou seja, módulo de senhas (atuavam na identificação, cadastramento de faxes genéricos, preenchimento e encaminhamento das senhas prévias), de prestadores (forneciam informações aos usuários) e o administrativo (atuavam nos assuntos que se referissem a contratos, cartões de filiados, informação de endereços de prestadoras, etc).

Os trabalhadores da empresa B eram formados por: gerente, supervisores, agentes líderes e operadores de telemarketing. Os supervisores tinham como tarefas: dar suporte técnico aos agentes de reservas, coordenar cursos, oferecer treinamento aos operadores novos, supervisionar e manter os padrões de qualidade, cuidar da parte administrativa e de recursos humanos reciclando trabalhadores quando necessário. Os agentes líderes tinham como tarefa dar suporte técnico aos operadores de telemarketing. A maior parte dos operadores de telemarketing estava no setor de atendimento que visava prestar informações aos usuários da companhia, vendendo passagens e recebendo críticas e sugestões. O setor de anomalias cuidava da qualidade das informações disponíveis no sistema, de forma a garantir a manutenção dos padrões de qualidade. $\mathrm{O}$ setor de off line/call back era formado por operadores que faziam ligações para os usuários da companhia com a finalidade de avisá-los de alguma modificação nos vôos ou solucionar problemas pendentes. O PTA cuidava das ordens de passagens.

Para a realização dessas tarefas era necessário que o operador de telemarketing das duas centrais tivesse as seguintes características: possuísse o ensino médio completo, tivesse idade igual ou superior a 18 anos e era desejável que possuísse alguma experiência anterior na função. $\mathrm{Na}$ empresa $\mathrm{B}$, recomendava-se ter conhecimentos em outra língua, principalmente a inglesa.

As tarefas dos operadores, em ambas as empresas, exigiam muita concentração mental, devido ao grande volume de informações a processar, o nível de responsabilidade do trabalho e a grande variedade de ligações que chegavam às centrais. Além disso, na central A o elevado número de manuais gerava uma grande carga de informações a serem processadas. Vale destacar também, o atendimento de muitas ligações sem interrupção, exigência dos usuários para atendimento rápido, 
monitoramento das ligações pela empresa e exigência dos supervisores para atender de forma adequada todos os telefonemas.

O horário de trabalho dos operadores de telemarketing das duas empresas estudadas era organizado em 6 horas diárias totalizando 36 horas semanais, sendo que alguns operadores da empresa A trabalhavam apenas 30 horas semanais, ou seja, não realizavam suas tarefas aos sábados e domingos.

As pausas de trabalho eram organizadas de modo que houvesse o maior número possível de operadores atendendo ligações. Desta forma, as pausas para lanches e descanso eram de curta duração e em pequeno número para que ocorressem poucas interrupções no trabalho. Em ambas as empresas eram dadas duas pausas, uma de 15 minutos (normalmente os operadores realizavam um lanche) e outra de 10 minutos, totalizando 25 minutos de pausa. Entretanto, foi verificado que habitualmente os operadores tinham uma tolerância de 10 minutos. Desta forma, verificamos que a interrupção no trabalho podia totalizar 35 minutos.

O ritmo de trabalho foi considerado intenso em ambas as empresas, pois o volume de chamadas das centrais era grande e, os operadores de telemarketing durante todo o trabalho tinham pouco tempo de pausa, bem como atendiam as ligações sem interrupção. $\mathrm{O}$ volume de trabalho das centrais cresceu e o número de funcionários não aumentou proporcionalmente; conseqüentemente, as exigências do trabalho se tornaram muito maiores. Além disso, o ritmo de trabalho imposto pelo sistema de distribuição de chamadas tornava-o fonte importante de tensão quando combinado a um excessivo número de ligações, pois impedia que o operador fizesse pequenas pausas entre as chamadas.

\section{2) Características da população estudada}

\subsection{1) Características sócio-demográficas}

A população foi formada por indivíduos de ambos os sexos, sendo 24,8\% homens e 75,2\% mulheres. Os operadores de telemarketing estavam compreendidos na faixa etária entre 19 e 52 anos, com predomínio entre 19 e 24 anos. A faixa etária com 
maior número de indivíduos do gênero masculino era entre 30 e 34 anos e no gênero feminino entre 19 e 24 anos. No total, a média de idade foi de 28,9 anos (desvio padrão $=7,6$ anos) e a mediana de 27,5 anos (Tabela 3).

Tabela 3 - Características quanto ao gênero e faixa etária dos operadores de telemarketing em número e porcentagem. São Paulo, 2002.

\begin{tabular}{crrrrrr}
\hline & \multicolumn{5}{c}{ Gênero } & \multicolumn{2}{c}{ Total } \\
Faixa Etária & \multicolumn{1}{c}{ Masculino } & \multicolumn{2}{c}{ Feminino } & \multicolumn{2}{l}{} \\
& $\mathrm{n}$ & \multicolumn{1}{c}{$\%$} & $\mathrm{n}$ & \multicolumn{1}{l}{$\%$} & $\mathrm{n}$ & $\%$ \\
\hline $19-24$ & 16 & 29,6 & 66 & 40,2 & 82 & 37,6 \\
$25-29$ & 11 & 20,4 & 33 & 20,1 & 44 & 20,2 \\
$30-34$ & 20 & 37,1 & 28 & 17,1 & 48 & 22,0 \\
$35-39$ & 4 & 7,4 & 18 & 11,0 & 22 & 10,1 \\
$40-52$ & 3 & 5,5 & 19 & 11,6 & 22 & 10,1 \\
\hline Total & $\mathbf{5 4}$ & $\mathbf{1 0 0 , 0}$ & $\mathbf{1 6 4}$ & $\mathbf{1 0 0 , 0}$ & $\mathbf{2 1 8}$ & $\mathbf{1 0 0 , 0}$
\end{tabular}

Quanto ao estado conjugal, a maioria era formada por indivíduos solteiros $65,6 \%$. Muitos trabalhadores não possuíam filhos $(71,2 \%)$ e tinham o ensino superior incompleto $(44,0 \%)$. Verifica-se que $33,9 \%$ eram estudantes e $12,4 \%$ trabalhavam em outro emprego (Tabela 4). 
Tabela 4 - Características gerais dos operadores de telemarketing em número e porcentagem segundo gênero. São Paulo, 2002.

\begin{tabular}{|c|c|c|}
\hline \multirow[t]{2}{*}{ Características dos trabalhadores } & \multicolumn{2}{|c|}{$\begin{array}{c}\text { Total } \\
(n=218)\end{array}$} \\
\hline & $\mathrm{n}$ & $\%$ \\
\hline \multicolumn{3}{|l|}{ Estado conjugal } \\
\hline Solteiro & 143 & 65,6 \\
\hline Casado & 52 & 23,9 \\
\hline Vive com companheiro (a) & 14 & 6,4 \\
\hline Separado (a) & 8 & 3,7 \\
\hline Viúvo (a) & 1 & 0,5 \\
\hline \multicolumn{3}{|l|}{ Número de filhos } \\
\hline Zero & 155 & 71,2 \\
\hline Um & 31 & 14,2 \\
\hline Dois & 26 & 11,9 \\
\hline Três & 6 & 2,7 \\
\hline \multicolumn{3}{|l|}{ Escolaridade } \\
\hline Ensino Médio completo & 56 & 25,7 \\
\hline Ensino Superior incompleto & 96 & 44,0 \\
\hline Ensino Superior completo & 62 & 28,4 \\
\hline Pós-Graduação & 4 & 1,8 \\
\hline \multicolumn{3}{|l|}{ Turnos de trabalho } \\
\hline Matutino & 72 & 33,0 \\
\hline Vespertino & 97 & 44,5 \\
\hline Noturno & 49 & 22,5 \\
\hline \multicolumn{3}{|l|}{ Outras características } \\
\hline Possuíam outro emprego & 27 & 12,4 \\
\hline Não possuíam outro emprego & 191 & 87,6 \\
\hline Estudantes universitários & 74 & 33,9 \\
\hline Não eram estudantes universitários & 144 & 66,1 \\
\hline
\end{tabular}

\subsection{2) Características quanto ao hábito de fumo e etilismo}

O hábito de fumar foi verificado em operadores que fumassem ou tivessem fumado mais de 20 maços de cigarros em toda a sua vida; desta forma, 15,6\% fumavam atualmente e 10,1\% pararam de fumar. Entre os que pararam de fumar, muitos $(36,4 \%)$ 
não fumavam há menos de 1 ano. Quanto aos fumantes e ex-fumantes, 64,3\% fumam/fumaram há menos de 10 anos e 35,7\% entre 11 e 20 anos. Quanto à quantidade, a maioria dos operadores fumava/fuma de 1 a 10 cigarros por dia (64,6\%) (Tabela 5).

Quanto à ingestão de álcool 45,0\% consumiam bebidas alcoólicas. Desse total, $28 \%$ consumiam bebidas alcoólicas semanalmente. Entre as bebidas consumidas, $42,9 \%$ consumiam cerveja; $42,9 \%$ vinho; $2,3 \%$ aguardente e $11,9 \%$ outras bebidas. A quantidade média consumida diariamente foi igual a 42,1 mililitros (Tabela 5). 
Tabela 5 - Características quanto ao hábito de fumo e etilismo entre os operadores de telemarketing em número e porcentagem. São Paulo, 2002.

\begin{tabular}{lrr}
\hline \multicolumn{1}{c}{ Características quanto ao hábito de fumo e etilismo } & \multicolumn{2}{c}{ Total $(\mathbf{n = 2 1 8})$} \\
& $\mathrm{n}$ & $\%$ \\
\hline É fumante? & 34 & 15,6 \\
Sim & 162 & 74,3 \\
Não & 22 & 10,1 \\
Parou de fumar & & \\
& & \\
Há quanto tempo parou de fumar? & 8 & 36,4 \\
Menos de 1 ano & 5 & 22,7 \\
1 a 2 anos & 5 & 22,7 \\
3 a 5 anos & 2 & 9,1 \\
a 10 anos & 2 & 9,1
\end{tabular}

Há quanto tempo fuma/fumou?

0 a 10 anos

11 ou mais anos

Quantos cigarros fuma/fumou ao dia?

1 a 10 cigarros

$141 \quad 64,6$

11 a 20 cigarros

6128,0

30 ou mais cigarros

136,0

Não respondeu

$3 \quad 1,4$

Bebe bebida alcóolica?

Sim

Não

Quais bebidas consome?

Cerveja

Vinho

Aguardente

$3 \quad 2,3$

Outras

Qual sua freqüência de consumo?

Nunca

$126 \quad 57,8$

Semanal

$61 \quad 28,0$

Mensal

$31 \quad 14,2$

Quantidade consumida diariamente em ml - média (desvio padrão)

$42,1 \quad(76,4)$


A freqüência do consumo de medicamentos para manter-se acordado foi igual a $0,9 \%$ e de medicamentos para dormir $3,2 \%$.

\section{3) Inquérito Nutricional}

\subsection{1) $O$ inquérito recordatório 24 horas}

Os resultados do IR24 horas mostraram que o consumo de médio de calorias foi igual a 2741,7 kcal para homens e 1612,4 kcal para mulheres (Tabela 6). Para verificar se o consumo de energia estava adequado entre os operadores, foi considerada a seguinte recomendação para indivíduos com atividade leve: homens $2700 \mathrm{kcal}$ e mulheres $2100 \mathrm{kcal}$, calculadas de acordo com o recomendado pela OMS/FAO/ONU (1998). Para obtenção da recomendação de energia utiliza-se a taxa de metabolismo basal (TMB) e o fator de atividade física (FAF). Desta forma, a TMB foi prescrita de acordo com os parâmetros: gênero, peso ideal (mulheres $=56,3 \mathrm{~kg}$ e homens $68,1 \mathrm{~kg}$, calculada a partir do IMC $=22 \mathrm{~kg} / \mathrm{m}^{2}$ e estatura média) e faixa etária entre 18 e 30 anos. O FAF utilizado foi igual a 1,55 (atividade leve), pois atividades do setor terciário podem ser consideradas leves sob o ponto de vista da atividade física empregada no seu exercício (BRASIL 1993).

Em relação à porcentagem de adequação de energia, os homens estavam consumindo, em média, 101,5\% da recomendação e as mulheres consumiram 76,7\% dessa recomendação (Tabela 7).

O consumo de proteínas variou entre 12 e 273 gramas para os homens e entre 7 e 185 gramas para mulheres. A porcentagem média de proteínas em relação ao valor calórico total (\%VCT) foi igual a 16,9\% para homens e 15,2\% para mulheres. Comparando com as recomendações da WHO/FAO (2003) (10 a $15 \%$ do VCT) o consumo médio está inadequado para homens e no limite da recomendação para mulheres (Tabela 6).

A porcentagem de adequação de proteínas foi calculada baseada na recomendação de $0,8 \mathrm{~g}$ de proteínas por quilograma de peso corporal. Desta forma, para homens cujo peso médio foi igual a 79,2 quilos, foram estipulados 63,4 gramas de 
proteínas e para mulheres cujo peso era de 62,4 quilos, o consumo de proteínas deveria ser de 49,9 gramas (OMS/FAO/ONU 1998). Verifica-se que os homens consomem, aproximadamente, $185,0 \%$ e as mulheres ingerem cerca de $130,0 \%$ (Tabela 7).

O consumo de carboidratos oscilou entre 18 e 935 gramas para os homens e entre 23 e 543 gramas para as mulheres. A porcentagem média de carboidratos em relação a \%VCT foi igual a 47,7\% para homens e 49,3\% para mulheres; consumo, portanto, inadequado de acordo com a recomendação da WHO/FAO (2003) (entre 55\% e 75\%). A ingestão de fibra total estava abaixo do recomendado em mulheres e homens de acordo com WHO/FAO (2003). As mulheres consumiram 10,3 gramas. Os homens ingeriram próximo do limite inferior (14,7 gramas). Segundo essa recomendação o consumo deve ser maior do que 25 gramas por dia (Tabela 6).

O consumo de lipídios oscilou entre 14 e 213 gramas para os homens e entre 5 e 202 gramas para mulheres. A porcentagem média de lipídios em relação as calorias totais (\%VCT) foi igual a 32,9\% para homens e 30,6\% para mulheres. Comparando esses resultados com o que recomenda a WHO/FAO (2003) (15-30\%) nota-se que o consumo estava inadequado. A ingestão de colesterol em homens estava acima do recomendado pela WHO/FAO (2003) (<300 mg/dia). Os homens ingeriram 433,8 miligramas. As mulheres consumiram 222,9 miligramas; consumo, portanto, adequado. Os homens ingeriram 41,4 gramas e as mulheres 22,8 gramas de lipídios insaturados. A recomendação para lipídios insaturados (monosaturados - MUFAs mais poliinsaturados -PUFAs - n-3 e n-6) é de 6-10\% VCT para poliinsaturados e para mono é a diferença entre lipídios totais e o total da soma entre lipídios saturados $(<10 \%$ VCT), poliinsaturados e ácidos graxos trans (<1\% VCT) (WHO/FAO 2003). Desta forma, foi calculada a partir da recomendação de energia, as quantidades (em gramas) máximas e mínimas de lipídios insaturados (MUFAs e PUFAs) que seriam recomendáveis: para homens 75-44 gramas e para mulheres 60-33 gramas. Portanto, o consumo está abaixo do recomendável para homens e mulheres (Tabela 6). 
Tabela 6 - Média, desvio padrão, valor máximo, valor mínimo e mediana do consumo de energia e macronutrientes em dias de trabalho e folga pelos operadores de telemarketing. São Paulo, 2002.

\begin{tabular}{|c|c|c|c|c|c|c|}
\hline Energia e Nutrientes & $\mathbf{n}$ & Média & DP & $\begin{array}{l}\text { Valor } \\
\text { Máx }\end{array}$ & $\begin{array}{l}\text { Valor } \\
\text { Min } \\
\end{array}$ & Mediana \\
\hline \multicolumn{7}{|l|}{ Energia (kcal) } \\
\hline Masculino & & 2741,7 & 834,4 & 5608 & 314 & 2650,3 \\
\hline Feminino & 164 & 1612,4 & 602,8 & 3833 & 115 & 1590,0 \\
\hline \multicolumn{7}{|l|}{ Proteína (g) } \\
\hline Masculino & 54 & 117,4 & 46,2 & 273 & 12 & 105,3 \\
\hline Feminino & 164 & 64,6 & 25,5 & 185 & 7 & 62,2 \\
\hline \multicolumn{7}{|l|}{ Carboidratos (g) } \\
\hline Masculino & 54 & 334,3 & 102,8 & 935 & 18 & 328,5 \\
\hline Feminino & 164 & 208,5 & 80,7 & 543 & 23 & 202,5 \\
\hline \multicolumn{7}{|l|}{ Lipídios (g) } \\
\hline Masculino & 54 & 103,9 & 36,1 & 213 & 14 & 98,8 \\
\hline Feminino & 164 & 61,7 & 32,3 & 202 & 5 & 57,2 \\
\hline \multicolumn{7}{|l|}{ \% de Proteínas } \\
\hline Masculino & 54 & 16,9 & 5,1 & 35 & 6 & 15,6 \\
\hline Feminino & 164 & 15,2 & 4,8 & 33 & 3 & 15,0 \\
\hline \multicolumn{7}{|l|}{$\%$ de Carboidratos } \\
\hline Masculino & 54 & 47,7 & 8,7 & 68 & 9 & 50,5 \\
\hline Feminino & 164 & 49,3 & 10,1 & 82 & 15 & 52,2 \\
\hline \multicolumn{7}{|l|}{ \% de Lipídios } \\
\hline Masculino & 54 & 32,9 & 6,7 & 52 & 16 & 33,8 \\
\hline Feminino & 164 & 30,6 & 7,4 & 57 & 4 & 32,3 \\
\hline \multicolumn{7}{|l|}{ Lipídios Insaturados (g) } \\
\hline Masculino & 54 & 41,4 & 18,4 & 98,6 & 12,8 & 36,6 \\
\hline Feminino & 164 & 22,8 & 12,2 & 0,25 & 77,1 & 19,5 \\
\hline \multicolumn{7}{|l|}{ Colesterol (mg) } \\
\hline Masculino & 54 & 433,8 & 581,1 & 123,8 & 4423,8 & 301,5 \\
\hline Feminino & 164 & 222,9 & 272,4 & 11,0 & 2259,3 & 145,6 \\
\hline \multicolumn{7}{|l|}{ Fibras (g) } \\
\hline Masculino & 54 & 14,7 & 7,5 & 45,2 & 3,3 & 13,0 \\
\hline Feminino & 164 & 10,3 & 5,4 & 30,2 & 0,9 & 8,9 \\
\hline
\end{tabular}


Tabela 7 - Média, desvio padrão e adequação do consumo de energia e proteínas em relação ao gênero dos operadores de telemarketing. São Paulo, 2002.

\begin{tabular}{lccc}
\hline & Média & $\begin{array}{c}\text { Desvio } \\
\text { Padrão }\end{array}$ & \% Adequação \\
\hline $\begin{array}{l}\text { Energia (kcal) } \\
\text { Masculino }\end{array}$ & 2741,7 & 834,4 & 101,5 \\
Feminino & 1612,4 & 602,8 & 76,7 \\
Proteína (g) & & & \\
Masculino & 117,4 & 46,2 & 185,2 \\
Feminino & 64,6 & 25,5 & 129,4 \\
\hline
\end{tabular}

\subsection{2) O Questionário de Freqüiência Alimentar}

\subsubsection{1) Avaliação do consumo de bebidas e alimentos estimulantes do sistema nervoso central (SNC)}

As bebidas e alimentos estimulantes consumidos em maior porcentagem foram: café e café com leite. Do total de operadores, 44,5\% referiram consumir café diariamente, $42,6 \%$ café com leite, $25,7 \%$ outro tipo de chá, $23,4 \%$ leite com achocolatado e 15,6\% bebida à base de cola (Figura 3 ). 
Figura 3 - Porcentagem de freqüência do consumo diário de alimentos e bebidas estimulantes do sistema nervoso central (SNC) pelos operadores de telemarketing $(n=218)$.

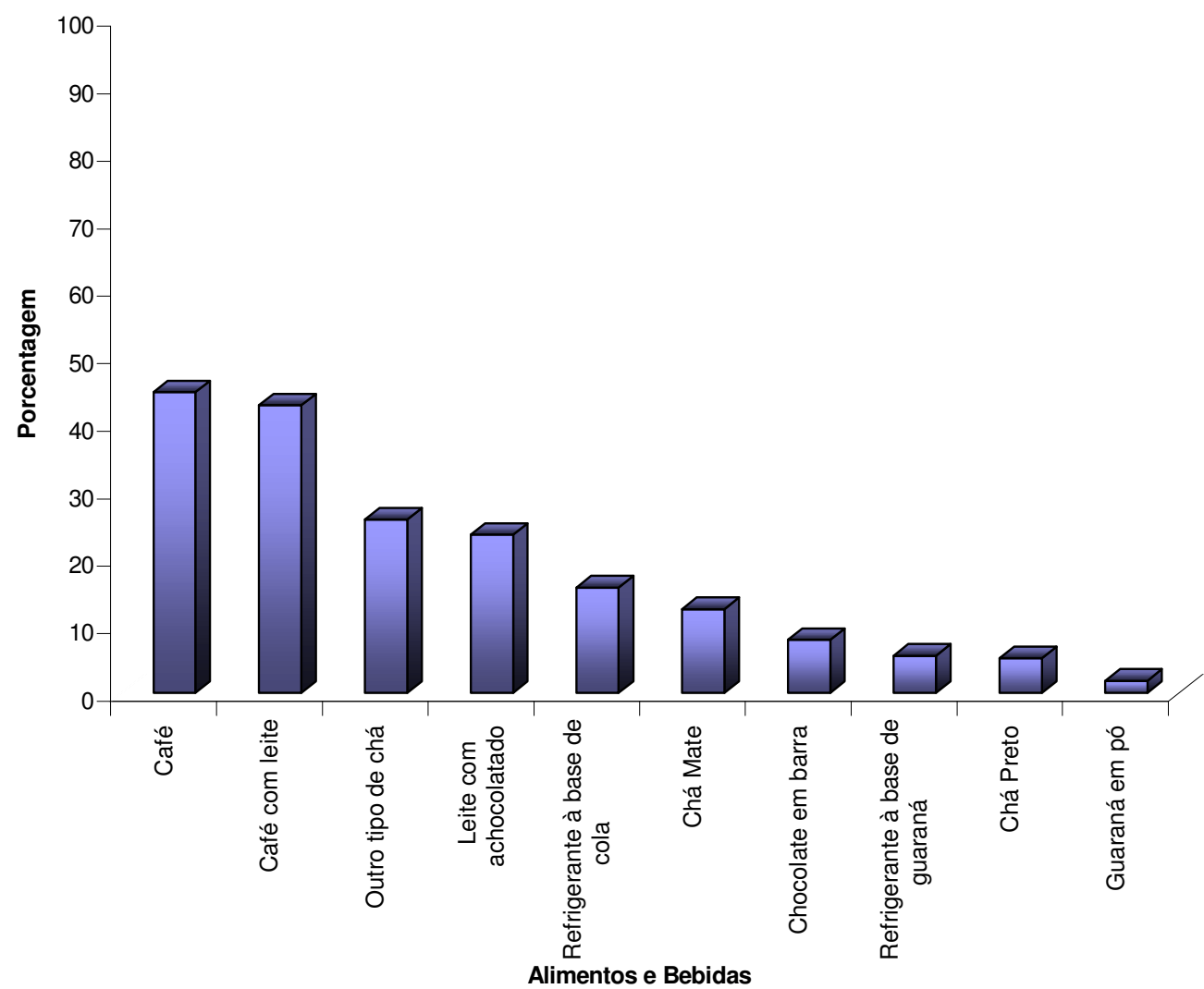

Analisando quanto às quantidades consumidas, em primeiro lugar, ingeriu-se maior quantidade diária de refrigerante à base de cola $(147 \mathrm{ml})$. Em segundo lugar, consumiu-se café (139,0 ml) e em terceiro café com leite (136,4 ml) (Tabela 8). 
Tabela 8 - Média, desvio padrão e mediana do consumo diário de bebidas e alimentos estimulantes do sistema nervoso central (SNC) pelos operadores de telemarketing (n=218). São Paulo, 2002.

\begin{tabular}{cccc}
\hline Bebidas e alimentos estimulantes & Média & Desvio padrão & Mediana \\
\hline Refrigerante à base de cola $(\mathrm{ml})$ & 147,6 & 240,5 & 43 \\
Café $(\mathrm{ml})$ & 139,0 & 407,9 & 25 \\
Café com leite $(\mathrm{ml})$ & 136,4 & 233,4 & 29 \\
Leite com achocolatado $(\mathrm{ml})$ & 128,2 & 219,6 & 31 \\
Chá Mate (ml) & 108,2 & 422,2 & 0 \\
Refrigerante à base de guaraná (ml) & 75,0 & 155,2 & 24 \\
Outro tipo de chá (ml) & 68,7 & 232,9 & 0 \\
Chá Preto (ml) & 25,2 & 132,4 & 0 \\
Chocolate em barra $(\mathrm{g})$ & 13,1 & 32,9 & 4 \\
Guaraná em pó $(\mathrm{g})$ & 0,0 & 0,4 & 0 \\
\hline
\end{tabular}

\subsubsection{2) Avaliação do consumo de lanches}

Os lanches com maior consumo foram: a categoria das bebidas lácteas e os sucos de frutas prontos para beber. Do total de operadores, 38,5\% consumiam bebidas lácteas diariamente, $38,1 \%$ ingeriam sucos de frutas pronto para beber e $22,9 \%$ frutas/barra de cereais (Figura 4). 
Figura 4 - Porcentagem de freqüência diária do consumo de lanches pelos operadores de telemarketing $(\mathrm{n}=218)$.

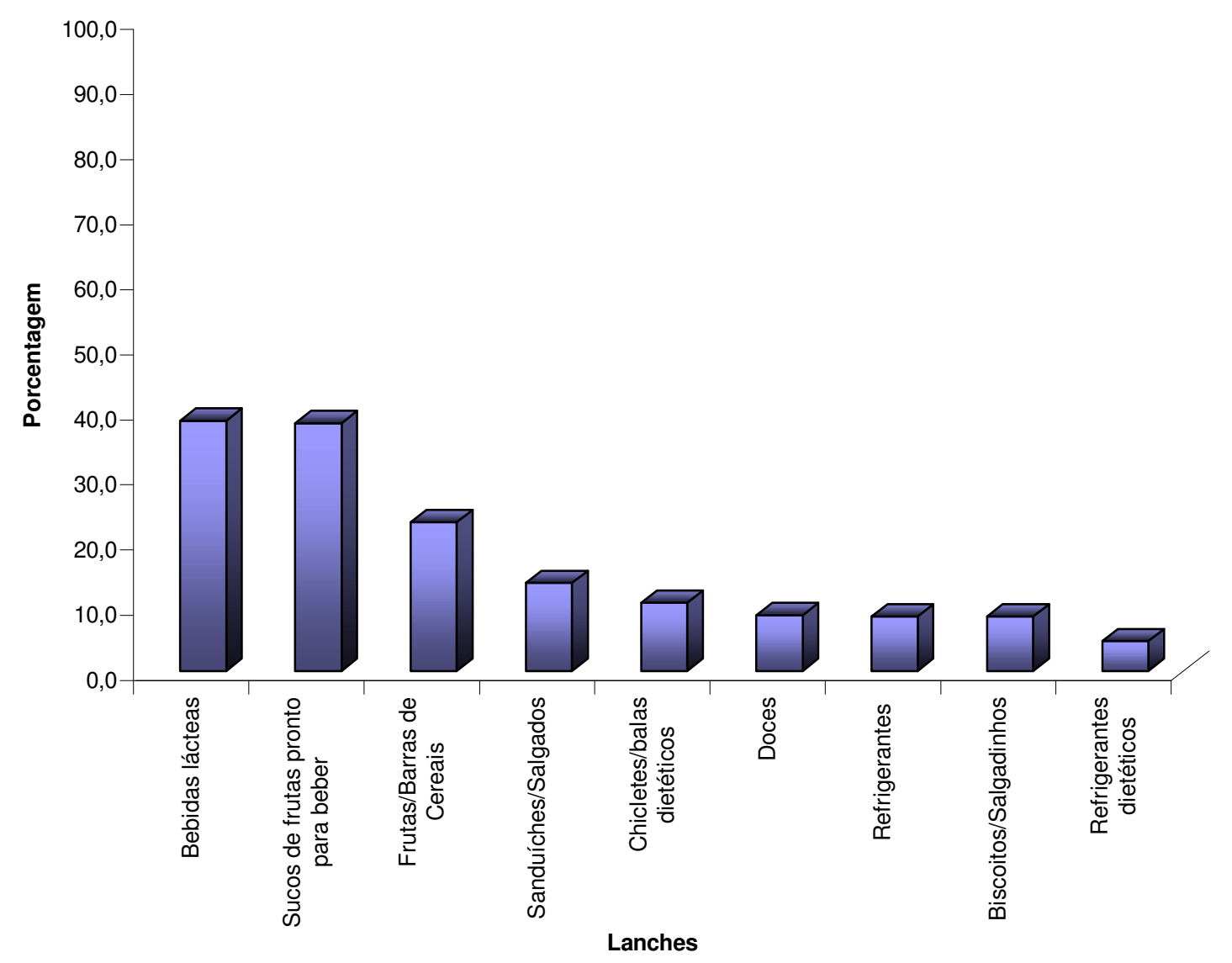

Em relação à quantidade consumida, identificou-se maior consumo diário de suco de frutas pronto para beber $(137,3 \mathrm{ml})$. Em seguida, ingeriam mais frutas/barra de cereais $(128,3 \mathrm{~g})$ e bebidas lácteas $(91,2 \mathrm{~g})$ (Tabela 9). 
Tabela 9 - Média, desvio padrão e mediana do consumo diário de lanches pelos operadores de telemarketing ( $\mathrm{n}=218$ ). São Paulo, 2002.

\begin{tabular}{crrr}
\hline Lanches & Média & Desvio padrão & Mediana \\
& & & \\
\hline Sucos de frutas prontos para beber (ml) & 137,3 & 454,0 & 36,0 \\
Frutas/Barras de Cereais (g) & 128,3 & 157,1 & 72,5 \\
Bebidas lácteas (ml) & 91,2 & 99,2 & 71,6 \\
Refrigerantes (ml) & 81,2 & 119,1 & 33,3 \\
Refrigerantes dietéticos (diet) (ml) & 44,3 & 126,3 & 0,0 \\
Sanduíches/Salgados (g) & 26,4 & 36,3 & 14,9 \\
Salgadinhos/Biscoitos (g) & 17,6 & 31,5 & 9,4 \\
Doces (g) & 11,8 & 29,2 & 5,3 \\
Chicletes/Balas dietéticos (g) & 1,4 & 4,6 & 0 \\
\hline
\end{tabular}

\subsection{3) Características da alimentação servida nas centrais de telemarketing}

A central A oferecia aos operadores de telemarketing um lanche composto pelos seguintes alimentos: pão francês, manteiga, margarina, chás, café, leite integral, açúcar e adoçante. Havia a possibilidade de adquirir alimentos como salgadinhos, salgados, suco de frutas, sanduíches, refrigerantes (com açúcar ou dietéticos), bebidas lácteas, biscoitos, balas (com açúcar ou dietéticos), chicletes (com açúcar ou dietéticos), doces e vitaminas na lanchonete do prédio onde localizava-se a central de atendimento.

A empresa B possuía um restaurante formado por dois salões: um superior e um inferior. Servia as seguintes refeições: café da manhã, almoço, lanche da tarde e jantar. A empresa oferecia dois cardápios, 1 e 2, que se distinguiam pelo custo - o cardápio 1 tinha um custo maior.

No restaurante superior, no almoço e jantar, era oferecido o cardápio 1. Esse era formado por dois tipos de arroz e de carne, cinco tipos de saladas, guarnições, maior variedade de sobremesas e bebidas, além de sopas e grelhados. No restaurante inferior, no almoço e jantar, era servido o cardápio 2, formado por arroz branco, feijão, um tipo 
de carne, guarnição, duas saladas, sobremesa e refresco (dietético e com açúcar). No café da manhã, no salão superior era servido: café, leite, achocolatado em pó, fruta, chá, três opções de pães, três tipos de recheios, podendo o usuário optar por apenas dois. $\mathrm{O}$ usuário podia escolher também por mingaus, cereais matinais, salgadinhos (batata frita, baconzitos etc), iogurtes etc, que eram pagos separadamente. O lanche da tarde era servido, também, no salão superior, que dispunha de várias opções de lanches, como sanduíches em diferentes tipos de pães, iogurtes, sorvetes, salgadinhos, salgados (coxinha, esfiha etc.), sucos etc.

No restaurante havia duas nutricionistas que preparavam os cardápios e faziam a gestão do restaurante. Os cardápios eram planejados de acordo com as necessidades de energia e nutrientes dos usuários (que incluíam não apenas os operadores, mas também todos os funcionários da empresa aérea desta unidade de São Paulo). Além disso, havia a possibilidade de adquirir alimentos em máquinas de venda, como salgadinhos, biscoitos, refrigerantes, barra de cereais, balas e chicletes (dietéticos e com açúcar).

\subsection{4) Características dos hábitos alimentares e alteração de peso em operadores de telemarketing}

Quanto ao número de refeições foi observado que os operadores faziam de três $(34,9 \%)$ a quatro refeições ao dia $(24,3 \%)$. A maioria dos operadores referiu almoçar $(84,9 \%)$. Os horários das refeições "às vezes eram fixos" em 43,6\% dos casos (Tabela $10)$.

Os operadores que referiram mudar sua alimentação no último mês ou fazer algum tipo de dieta para perder peso foram $24,3 \%$, sendo que muitos seguiam essa dieta há mais de 60 dias $(42,2 \%)$ (Tabela 10$)$. 
Tabela 10 - Características dos hábitos alimentares em operadores de telemarketing em número e porcentagem (n=218). São Paulo, 2002.

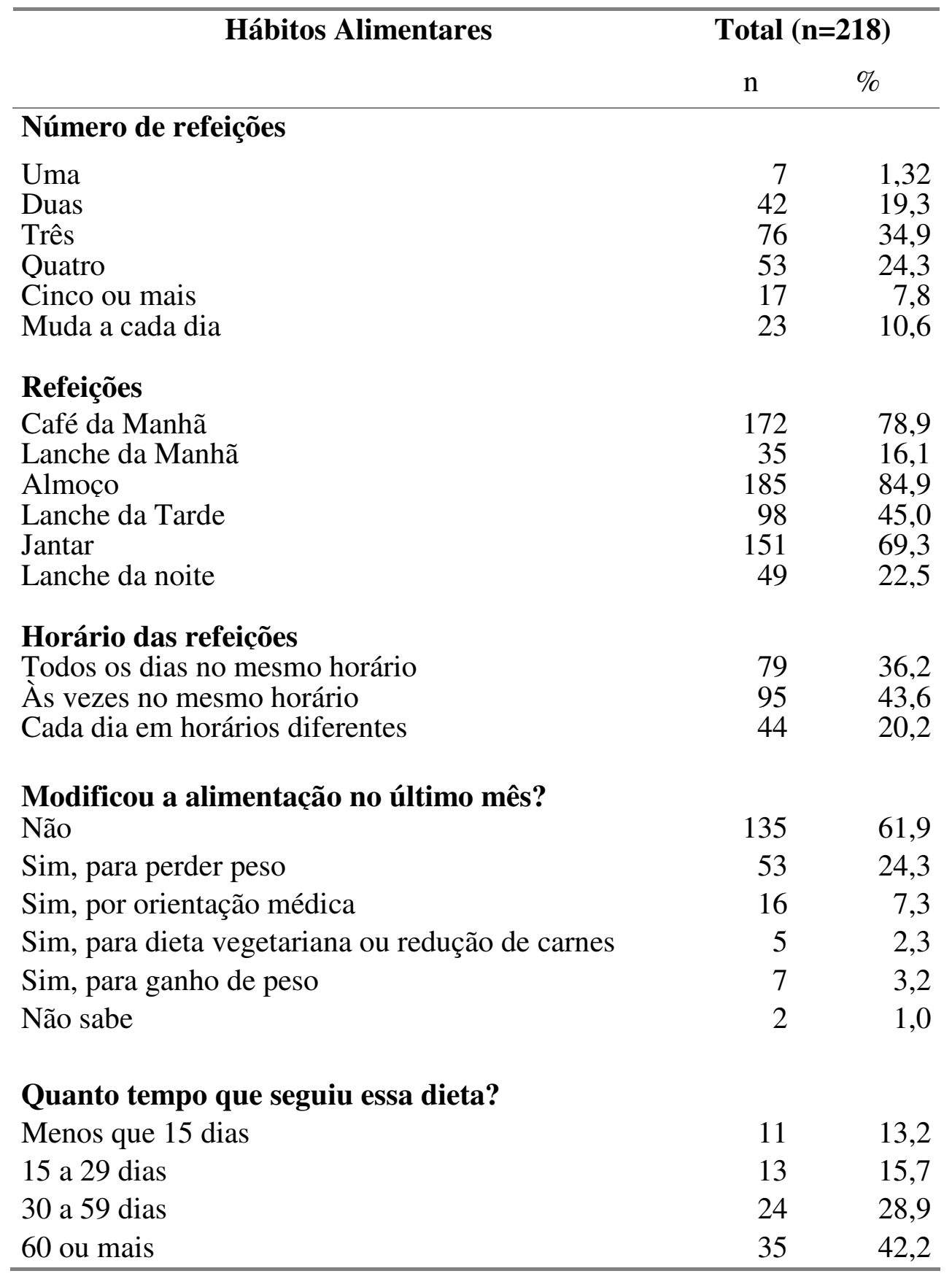

Foi verificado alteração de peso após o início na profissão de operador de telemarketing. Do total, 45,0\% referiram aumentar seu peso depois de começar a 
trabalhar como operador, para 38,5\% não houve aumento, enquanto 7,3\% diminuíram de peso e 9,2\% não souberam opinar (Tabela 11).

Em 46,3\% dos operadores essa variação de peso haveria relação com o trabalho, enquanto 11,0\% responderam que não e 42,7\% não souberam opinar (Tabela 11).

A razão mais referida para o ganho de peso, segundo os operadores, foi o trabalho ser realizado cerca de $95 \%$ na posição sentada não possibilitando o movimento do corpo $(43,1 \%)$. Outra razão eram os horários dos lanches diferentes a cada dia (11,9\%), ou seja, a irregularidade dos horários para essa refeição, como descreve o operador: "porque os horários de lanches são flexíveis e não é possível determinar um mesmo horário todo dia”. Além disso, para 11,9\% dos operadores o fato de beliscar alimentos no trabalho e ficar sentado logo em seguida foi responsável pelo ganho de peso, como descreve o operador: "porque só ficamos sentados e comendo" (Tabela 11).

Os operadores referiram alterar o consumo alimentar em função da ansiedade do trabalho em 28,9\% dos casos. Em 66,5\% disseram que nunca tinham alterado sua alimentação em função da ansiedade do trabalho (4,6\% não souberam opinar) (Tabela 11).

Em relação ao trabalho em turnos, 42,2\% não alteraram o peso em função de trabalhar em turnos. Do total de operadores após trabalharam em turnos, 33,5\% ganharam peso, $11 \%$ diminuíram e 13,3\% não souberam responder (Tabela 11).

Do total de trabalhadores, $41,3 \%$ referiram variar recentemente de peso. Dos operadores que modificaram de peso na vida adulta, 40,9\% aumentaram entre 1 e 10 quilos. Nota-se que 15,7\% ganharam mais de 15 quilos na vida adulta. Dos que diminuíram de peso, $15,7 \%$ abaixaram o peso entre 1 e 5 quilos, 5,0\% entre 5,1 e 20 quilos (Tabela 11). 
Tabela 11 - Características da alteração de peso em operadores de telemarketing em número e porcentagem (n=218). São Paulo, 2002.

Alteração de peso em operadores de telemarketing Total $(\mathbf{n}=\mathbf{2 1 8})$

\begin{tabular}{c} 
Alteração de peso em operadores de telemarketing \\
\hline Seu peso alterou depois de iniciado o trabalho como operador?
\end{tabular}

Sim, aumentou de peso

$\mathrm{n}$ $\%$

Sim, diminuiu de peso $98 \quad 45,0$

Não alterou

$16 \quad 7,3$

Não soube responder

$84 \quad 38,5$

$20 \quad 9,2$

A alteração de peso teve relação com o trabalho?

Sim

Não

$24 \quad 11,0$

Não soube opinar

$93 \quad 42,7$

Por que a alteração de peso teve relação com o trabalho $(n=101)$ ?

Trabalho predominantemente sentado

Horários de lanches diferentes a cada dia

Beliscar alimentos e permanecer na posição sentada

Outras razões

$33 \quad 33,1$

A ansiedade no trabalho alterou seu consumo alimentar?

Alterou o consumo alimentar

Não alterou o consumo alimentar

$145 \quad 66,5$

Não soube responder

$10 \quad 4,6$

Seu peso alterou depois de iniciado o trabalho em turnos?

Sim, aumentou de peso

Sim, diminuiu de peso

Não alterou

Não soube responder

$29 \quad 13,3$

Houve variação recente de peso?

Sim

Não

Não soube responder

$43 \quad 19,7$

Quantos quilos variou na vida adulta? $(\mathbf{n}=198)$

- 20 a $-5,1$ quilos

$-1,0$ a $-5,0$ quilos

1,0 a 5,0 quilos

5,1 a 10,0 quilos 


\subsection{5) Avaliação antropométrica}

Os homens tinham peso médio igual a 79,2 quilos e as mulheres 62,4 quilos. A estatura média em homens foi de 1,76 metros e nas mulheres 1,60 metros. O IMC médio em homens era de $25,4 \mathrm{~kg} / \mathrm{m}^{2}$ e em mulheres $24,0 \mathrm{~kg} / \mathrm{m}^{2}$. A CC média em mulheres foi igual a 75,4 centímetros e em homens 88,0 centímetros (Tabela 12).

Os resultados obtidos sobre o IMC mostraram que 50,0\% dos homens estavam normais e 65,6\% das mulheres. Entre os homens, 35,2\% estavam com sobrepeso e $21,3 \%$ das mulheres. Entre os homens $13,0 \%$ estavam obesos e 1,8\% desnutridos. No total das mulheres, $8,1 \%$ estavam obesas e 5,0\% estavam desnutridas (Tabela 12).

Quanto aos dados da CC, pode-se notar que 14,4\% estavam com risco aumentado para doenças metabólicas associadas à obesidade, sendo que $11,1 \%$ são homens e $15,5 \%$ são mulheres. Verifica-se que $16,7 \%$ dos homens e 9,9\% das mulheres estão com risco muito aumentado para doenças cônicas não-transmissíveis associadas à obesidade (11,6\% do total) (Tabela 12$)$. 
Tabela 12 - Características antropométricas dos operadores de telemarketing segundo gênero em número e porcentagem. São Paulo, 2002.

\begin{tabular}{lrrr}
\hline & \multicolumn{2}{c}{ Gênero } & \\
Características antropométricas & Masculino & \multicolumn{1}{c}{ Feminino } & \multicolumn{1}{c}{ Total } \\
\hline Peso médio (desvio padrão) $(\mathrm{kg})$ & $79,2(14,3)$ & $62,4(13,5)$ & $66,6(15,5)$ \\
Estatura média (desvio padrão) (m) & $1,76(0,7)$ & $1,60(0,1)$ & $1,64(0,1)$ \\
IMC médio (desvio padrão) (kg/m²) & $25,4(4,0)$ & $24,0(4,6)$ & $24,3(4,5)$ \\
CC média (desvio padrão) (cm) & $88,0(11,7)$ & $75,4(10,6)$ & $78,4(12,2)$ \\
Classificação do IMC (kg/m $)$ & & & \\
Desnutridos n (\%) & $1(1,8)$ & $8(5,0)$ & $9(4,2)$ \\
Normais n (\%) & $27(50,0)$ & $105(65,6)$ & $132(61,7)$ \\
Sobrepeso n (\%) & $19(35,2)$ & $34(21,3)$ & $53(24,8)$ \\
Obesos n (\%) & $7(13,0)$ & $13(8,1)$ & $20(9,3)$ \\
Classificação da CC (cm) & & & \\
Normais n (\%) & $39(72,2)$ & $120(74,5)$ & $159(74,0)$ \\
Aumentado n (\%) & $6(11,1)$ & $25(15,5)$ & $31(14,4)$ \\
Muito aumentado n (\%) & $9(16,7)$ & $16(9,9)$ & $25(11,6)$ \\
\hline
\end{tabular}

Os resultados da avaliação antropométrica foram analisados segundo faixa etária. No total, a classificação em relação às faixas etárias mostrou maior proporção de indivíduos com risco muito aumentado para doenças crônicas degenerativas nãotransmissíveis associadas à obesidade nas faixas etárias entre 25 e 34 anos $(11,4 \%)$ e maior que 35 anos (20,3\%). Em homens, entre 19 e 24 anos e com mais de 30 anos $25 \%$ e $28,6 \%$, respectivamente estão com risco muito aumentado. Em mulheres observa-se aumento do risco com o decorrer da idade. Operadoras acima de 35 anos têm 20,3\%, entre 25 e 34 anos $11,4 \%$ e entre 19 e 24 anos 5,1\% de risco muito aumentado (Tabela 13).

Os dados segundo faixa etária do IMC mostraram que entre os homens acima de 35 anos, 42,9\% estavam obesos e entre 19 e 24 anos 18,7\%. A obesidade em mulheres aumentou conforme aumentava a idade (19-24 anos - 3\%, 25-34 anos - 10\%, maior 35 anos $-16,2 \%)$. A desnutrição concentrou-se em mulheres e nas faixas etárias entre 19 e 
$24 \operatorname{anos}(7,6 \%)$ e entre 25 e 34 anos (3,3\%). Um homem estava desnutrido (14,3\%). O sobrepeso concentrou-se na faixa etária entre 25 e 34 anos para homens $(48,4 \%)$ e para mulheres $(21,7 \%)$. (Tabela 13).

Os dados da Pesquisa Nacional sobre Saúde e Nutrição - PNSN para a população do Sudeste urbano foram comparados com os dados dessa pesquisa de acordo com as faixas etárias compreendidas entre 19 e 24, 25 e 34, 35 e 44 e 45 e 54 anos (COITINHO et al. 1991).

Em homens, na faixa etária entre 25 e 34 anos, o sobrepeso foi mais prevalente $(48,4 \%)$ em relação à pesquisa nacional $(23,3 \%)$. A obesidade estava em maior proporção em todas as faixas etárias $(18,7 \% ; 6,4 \%$ e $42,9 \%)$ do que a registrada pela PNSN $(2,1 \% ; 4,7 \% ; 7,4 \%$; e 8,9\%) (Tabela 13$)$.

Em mulheres na faixa etária entre 19 e 24 anos, o sobrepeso (16,7\%) está acima dos dados da pesquisa nacional (13,8\%). Verificou-se maior prevalência de obesidade nas faixas etárias superiores ou iguais a 25 anos $(10,0 \%$ e 16,2\%) em relação à PNSN $(9,2 \%$ e $13,7 \%)$ (Tabela 13$)$. 
Tabela 13 - Distribuição em número e porcentagem do índice de massa corporal e circunferência da cintura, segundo faixas etárias e gênero. São Paulo, 2002.

\begin{tabular}{|c|c|c|c|c|c|c|c|}
\hline & \multicolumn{4}{|c|}{ IMC } & \multicolumn{3}{|c|}{$\mathrm{CC}$} \\
\hline Idade (anos) & Desnutridos & Normais & Sobrepeso & Obesos & Normais & Aumentado & $\begin{array}{c}\text { Muito } \\
\text { aumentado }\end{array}$ \\
\hline \multicolumn{8}{|l|}{ Homens } \\
\hline $19-24$ & - & $11(68,8)$ & $2(12,5)$ & $3(18,7)$ & $12(75,0)$ & - & $4(25,0)$ \\
\hline $25-34$ & - & $14(45,2)$ & $15(48,4)$ & $2(6,4)$ & $11(28,2)$ & $4(12,9)$ & $3(9,7)$ \\
\hline 35 ou mais & $1(14,3)$ & $2(28,6)$ & $1(14,3)$ & $3(42,9)$ & $16(59,3)$ & $2(28,6)$ & $2(28,6)$ \\
\hline \multicolumn{8}{|l|}{ Mulheres } \\
\hline $19-24$ & $5(7,6)$ & $48(72,7)$ & $11(16,7)$ & $2(3,0)$ & $58(87,8)$ & $5(6,0)$ & $4(4,5)$ \\
\hline $25-34$ & $2(3,3)$ & $39(65,0)$ & $13(21,7)$ & $6(10,0)$ & $45(73,7)$ & $12(20,0)$ & $7(11,6)$ \\
\hline 35 ou mais & - & $23(62,2)$ & $8(21,6)$ & $6(16,2)$ & $18(48,6)$ & $8(21,6)$ & $5(13,5)$ \\
\hline \multicolumn{8}{|l|}{ Total } \\
\hline $19-24$ & $5(6,1)$ & $59(71,9)$ & $13(15,9)$ & $5(6,1)$ & $70(88,6)$ & $5(6,3)$ & $4(5,1)$ \\
\hline $25-34$ & $2(2,2)$ & $53(58,3)$ & $28(30,7)$ & $8(8,8)$ & $56(70,9)$ & $14(17,7)$ & $9(11,4)$ \\
\hline 35 ou mais & $1(2,3)$ & $25(56,9)$ & $9(20,4)$ & $9(20,4)$ & $34(53,1)$ & $17(26,6)$ & $13(20,3)$ \\
\hline
\end{tabular}

\section{4) Situação dos turnos de trabalho nas centrais}

As centrais de atendimento telefônico funcionavam 24 horas ao dia. $\mathrm{O}$ trabalho era dividido em turnos de trabalho fixos. Os turnos de trabalho de ambas as empresas eram: manhã (horários de entrada entre 6 e 9 horas), tarde (horários de entrada entre 12 e 16 horas), noite (entrada às 18 e 19 horas) e madrugada (com entrada à meia-noite).

$\mathrm{Na}$ central A, todos os operadores trabalhavam durante os dias de semana e nos fins de semana era realizada uma escala de plantões. Na central B, trabalhavam durante 
os dias de semana e revezavam-se durante os fins de semana, contudo tinham fins de semana de folga.

Quanto às escalas de trabalho, os operadores da empresa A, que trabalhavam 36 horas, revezavam-se em duas turmas de trabalho. Na central B, havia quatro turmas, sendo que quando duas turmas trabalhavam no domingo a semana seguinte era o seu fim de semana de folga (Tabela 14).

Tabela 14 - Escalas de trabalho dos operadores de telemarketing das centrais A e B. São Paulo, 2002.

\begin{tabular}{|c|c|c|c|c|c|c|c|}
\hline Semanas & $\begin{array}{l}\text { Segunda- } \\
\text { feira }\end{array}$ & $\begin{array}{l}\text { Terça- } \\
\text { feira }\end{array}$ & $\begin{array}{c}\text { Quarta- } \\
\text { feira }\end{array}$ & $\begin{array}{c}\text { Quinta- } \\
\text { feira }\end{array}$ & $\begin{array}{l}\text { Sexta- } \\
\text { feira }\end{array}$ & Sábado & Domingo \\
\hline \multicolumn{8}{|l|}{ Central A } \\
\hline 1 & Todos & Todos & Todos & Todos & Todos & Turma B & Turma A \\
\hline 2 & Todos & Todos & Todos & Todos & Todos & Turma A & Turma B \\
\hline \multicolumn{8}{|l|}{ Central B } \\
\hline 1 & Todos & Todos & Todos & Todos & Todos & Turma B e D & Turma A e C \\
\hline 2 & Todos & Todos & Todos & Todos & Todos & Turma E e F & Turma B e D \\
\hline 3 & Todos & Todos & Todos & Todos & Todos & Turma A e C & Turma E e F \\
\hline
\end{tabular}

As turmas de trabalho eram organizadas de tal forma que operadores do mesmo turno de trabalho ficassem em turmas diferentes, por exemplo, a turma A era formada por indivíduos que trabalhavam em diferentes turnos de trabalho.

Foi observado que as escalas de trabalho não eram obedecidas com muito rigor, pois havia uma intensa troca dos horários de trabalho, tanto trocas entre as turmas quanto trocas entre os turnos. O motivo para haver tantas trocas era a organização dos operadores para terem fins de semana de folga. 


\subsection{1) Características da população em relação aos turnos de trabalho}

A média de idade para os operadores do turno matutino foi igual a 30,8 anos (desvio padrão $=7,9$ anos), do turno vespertino 26,9 anos (desvio padrão $=7,1$ anos) e do turno noturno 30,2 anos (desvio padrão $=7,3$ anos). A mediana para os turnos matutino, vespertino e noturno foi 29,24 e 30 anos respectivamente.

Observaram-se diferenças estatisticamente significantes entre as faixas etárias $(\mathrm{p}=0,04)$. Os trabalhadores do turno da manhã e da tarde estavam concentrados na faixa etária entre 19 e 24 anos, sendo que no turno vespertino 50,5\% estavam nesse grupo etário. No turno noturno houve predomínio das faixas etárias entre 19 e 24 anos e 30 e 34 anos (Tabela 15).

Foi verificado que existiam diferenças estaticamente significantes entre os turnos de trabalho e o gênero dos trabalhadores $(\mathrm{p}=0,00)$. As mulheres representaram cerca de $80,0 \%$ da população de trabalhadores nos turnos manhã e tarde. No turno da noite, elas predominavam em $57,1 \%$. Os homens eram mais prevalentes no turno noturno em relação aos outros turnos (42,9\% contra 19,5\% do turno matutino e 19,6\% do vespertino) (Tabela 15).

Entre os turnos de trabalho, foram observadas diferenças estaticamente significantes quanto ao estado conjugal $(\mathrm{p}=0,04)$. Os indivíduos solteiros estavam em maior proporção no turno da tarde do que nos demais $(75,3 \%$ contra $56,9 \%$ do turno matutino e $59,2 \%$ do turno vespertino). Os casados representaram 33,3\% e 28,6\% da população dos turnos matutino e noturno, respectivamente (Tabela 15).

Não foram verificadas diferenças estatisticamente significantes entre turnos de trabalho e o número de filhos, apesar dos operadores do turno da tarde terem menor número de filhos do que os outros turnos $(77,3 \%$ contra $65,3 \%$ do turno matutino e $67,4 \%$ do turno vespertino) (Tabela 15 ).

Possuir o ensino superior incompleto foi mais prevalente para operadores do turno da tarde $(48,5 \%)$ e da noite $(46,9 \%)$, apesar de não diferirem significantemente entre os turnos $(\mathrm{p}=0,47)$. No turno da manhã predominaram os operadores com o ensino superior completo/pós-graduação (37,5\%) (Tabela 15).

Os estudantes universitários eram mais prevalentes no turno da tarde $(50,5 \%)$ e diferiram significantemente entre os turnos de trabalho $(\mathrm{p}=0,00)$. Possuir um segundo 
emprego foi mais freqüente para os operadores do turno noturno $(26,5 \%)$ e essa diferença foi estatisticamente significante $(\mathrm{p}=0,00)$ (Tabela 15).

Tabela 15 - Características sócio-demográficas dos operadores de telemarketing em relação ao seu turno de trabalho em número e porcentagem. São Paulo, 2002.

\begin{tabular}{|c|c|c|c|c|c|c|c|}
\hline \multirow{2}{*}{$\begin{array}{l}\text { Características dos } \\
\text { trabalhadores }\end{array}$} & \multicolumn{2}{|c|}{ Manhã (n=72) } & \multicolumn{2}{|c|}{ Tarde $(n=97)$} & \multicolumn{2}{|c|}{ Noite(n=49) } & \multirow[t]{2}{*}{$\mathbf{p}$} \\
\hline & $\mathrm{n}$ & $\%$ & $\mathrm{n}$ & $\%$ & $\mathrm{n}$ & $\%$ & \\
\hline \multicolumn{8}{|l|}{ Faixa etária } \\
\hline 19-24 & 20 & 27,8 & 49 & 50,5 & 13 & 26,5 & $0,04 *^{1}$ \\
\hline $25-29$ & 17 & 23,6 & 17 & 17,5 & 10 & 20,4 & \\
\hline $30-34$ & 16 & 22,2 & 19 & 19,6 & 13 & 26,5 & \\
\hline $35-39$ & 8 & 11,1 & 6 & 6,2 & 8 & 16,3 & \\
\hline $40-52$ & 11 & 15,3 & 6 & 6,2 & 5 & 10,2 & \\
\hline \multicolumn{8}{|l|}{ Sexo } \\
\hline Masculino & 14 & 19,5 & 19 & 19,6 & 21 & 42,9 & $0,0 *^{1}$ \\
\hline Feminino & 58 & 80,5 & 78 & 80,4 & 28 & 57,1 & \\
\hline \multicolumn{8}{|l|}{ Estado civil } \\
\hline Solteiro & 41 & 56,9 & 73 & 75,3 & 29 & 59,2 & $0,04 *^{2}$ \\
\hline Casado (a) & 24 & 33,3 & 14 & 14,2 & 14 & 28,6 & \\
\hline Vive com companheiro (a) & 3 & 4,2 & 7 & 7,2 & 4 & 8,2 & \\
\hline Separado (a) & 4 & 5,6 & 3 & 3,1 & 1 & 2,0 & \\
\hline Viúvo (a) & 0 & 0,0 & 0 & 0,0 & 1 & 2,0 & \\
\hline \multicolumn{8}{|l|}{ Número de filhos } \\
\hline Nenhum & 47 & 65,3 & 75 & 77,3 & 33 & 67,4 & $0,47^{1}$ \\
\hline Um & 13 & 18,1 & 10 & 10,3 & 8 & 16,3 & \\
\hline Dois/Três & 12 & 16,7 & 12 & 12,4 & 8 & 16,3 & \\
\hline \multicolumn{8}{|l|}{ Escolaridade } \\
\hline Ensino Médio completo & 19 & 26,4 & 25 & 25,8 & 12 & 24,5 & $0,47^{1}$ \\
\hline Ensino Superior incompleto & 26 & 36,1 & 47 & 48,5 & 23 & 46,9 & \\
\hline Ensino Superior completo/ Pós- & 27 & 37,5 & 25 & 25,8 & 14 & 28,6 & \\
\hline \multicolumn{8}{|l|}{ Graduação } \\
\hline Outras características & & & & & & & \\
\hline Possuíam outro emprego & 8 & 11,1 & 6 & 6,2 & 13 & 26,5 & $0,00 * 1$ \\
\hline Não possuíam outro emprego & 64 & 88,9 & 91 & 93,8 & 36 & 73,5 & \\
\hline Estudantes universitários & 14 & 19,4 & 49 & 50,5 & 11 & 22,5 & $0,00 * 1$ \\
\hline Não eram estudantes universitários & 58 & 80,6 & 48 & 49,5 & 38 & 77,6 & \\
\hline
\end{tabular}


Os trabalhadores do turno noturno diferiram significantemente $(\mathrm{p}=0,00)$ quanto à pratica do hábito de fumar em relação aos outros turnos. Do total, $6,2 \%$ dos operadores do turno da tarde, $15,3 \%$ do turno da manhã e $34,7 \%$ do turno da noite fumavam (Tabela 16).

Não houve diferenças estatisticamente significantes em relação à quantidade de cigarros e os turnos de trabalho $(\mathrm{p}=0,26)$. Do total, $50,0 \%$ dos operadores do turno da manhã; $76,5 \%$ do turno da tarde e $19,1 \%$ do turno da noite fumavam entre 1 e 10 cigarros ao dia (Tabela 16).

O consumo de bebidas alcoólicas foi maior nos operadores do turno noturno $(59,2 \%)$, apesar de não existirem diferenças estatisticamente significantes $(p=0,06)$ entre os turnos. No turno da tarde $(39,0 \%)$ e manhã $(41,2 \%)$ essa proporção foi menor (Tabela 16).

O consumo do tipo de bebidas não diferiu significantemente entre os grupos $(\mathrm{p}=$ 0,80). Entre as bebidas, a mais preferida foi a cerveja para $45,1 \%$ dos operadores do turno noturno, $47,6 \%$ do turno matutino e $45,3 \%$ do turno vespertino (Tabela 16).

Quanto à freqüência de consumo de bebidas alcoólicas, não foram identificadas diferenças estatisticamente significantes $(p=0,13)$ entre os turnos. Contudo, observa-se que os operadores do turno noturno ingeriam com maior freqüência semanal $(38,8 \%)$ e mensal $(18,4 \%)$ em relação aos outros turnos (Tabela 16).

Quanto à quantidade média consumida de bebidas alcoólicas, não foram observadas diferenças significantes no consumo $(\mathrm{p}=0,05)$, embora o turno noturno ingerisse maior quantidade (60,2 ml) (Tabela 16). 
Tabela 16 - Características dos hábitos de fumar e de etilismo em operadores de telemarketing segundo turnos de trabalho em número e porcentagem. São Paulo, 2002.

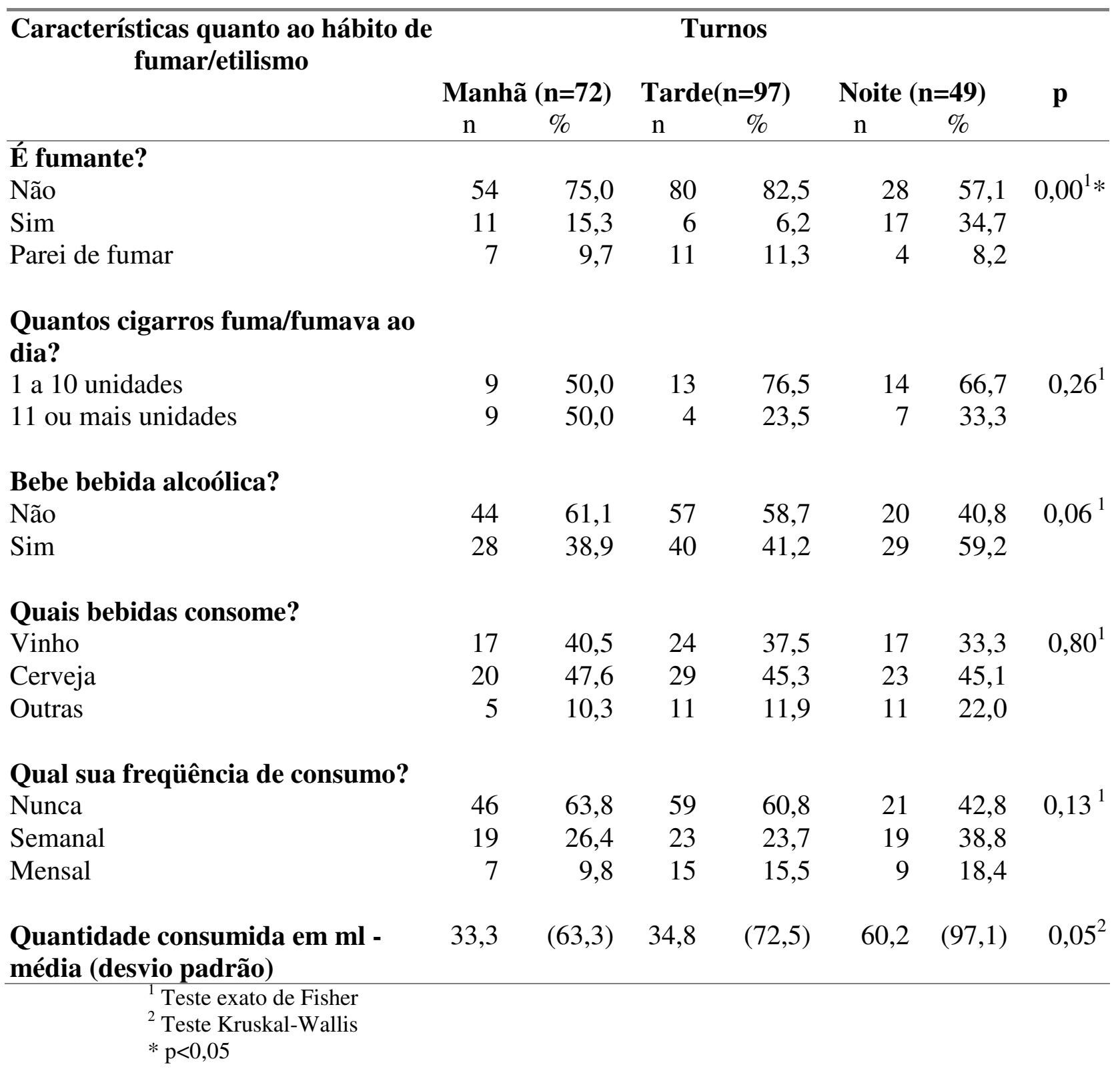

\subsection{2) Inquérito nutricional e os turnos de trabalho}

\subsubsection{1) O inquérito recordatório 24 horas}

Em relação aos turnos de trabalho e ao consumo médio de calorias não foram observadas diferenças estatisticamente significantes (Tabelas 17 e 18). Contudo, 
observa-se que os operadores do gênero masculino do turno noturno ingeriram mais calorias $(2864,2 \mathrm{kcal})$ em relação aos outros turnos de trabalho (2635,4 do turno vespertino e 2702,1 kcal do turno matutino). As operadoras do turno da noite consumiam menos calorias $(1402,5 \mathrm{kcal})$ do que suas companheiras dos outros turnos (1673,8 do turno vespertino e $1631,2 \mathrm{kcal}$ do turno matutino) (Tabelas 17 e 18).

Para realizar a adequação de energia, considerando os mesmo critérios descritos anteriormente, para homens a recomendação foi igual a $2700 \mathrm{kcal}$ e para mulheres 2100 kcal.

A adequação percentual das calorias da dieta para os homens do turno noturno ultrapassou a recomendação de energia. Os operadores do turno noturno ingeriram $106,1 \%$ da recomendação de calorias, os do turno vespertino $97,6 \%$ e do turno matutino $100,0 \%$. As mulheres do turno noturno consumiram abaixo do ingerido pelas trabalhadoras dos outros turnos de trabalho (consumiram 66,8\% comparado com 79,7\% do turno vespertino e 77,7\% do turno matutino) (Tabela 19).

Não foram verificadas diferenças significantes entre os turnos de trabalho e consumo de proteínas, carboidratos, lipídios, fibras, lipídios insaturados e colesterol, bem como quanto às porcentagens dos macronutrientes em relação ao valor calórico total (\%VCT). Embora os homens do turno noturno consumissem maiores quantidades de proteínas (122,1 gramas em relação a 115,7 gramas do turno vespertino e 112,6 gramas do matutino), carboidratos (339,1 gramas comparado com 329,2 gramas do turno vespertino e 334,0 gramas do matutino) e lipídios totais (98,5 gramas em relação a 99,8 gramas do turno vespertino e 111,2 gramas do matutino), além do percentual de proteínas (17,5\% comparado com 17,3\% do turno vespertino e $15,5 \%$ do matutino) e lipídios (34,6\% em relação a 33,2\% do turno vespertino e 30,0\% do matutino) em relação ao valor calórico total da dieta $(\% \mathrm{VCT})$. O consumo de fibra total foi menor em homens do turno noturno (13,8 gramas) comparando-se com o turno vespertino e matutino (15,8 gramas do turno vespertino e 14,6 gramas do matutino) (Tabelas 17 e 18).

As mulheres do turno noturno ingeriram teores inferiores de lipídios (58,8 gramas comparando com 63,2 gramas do turno vespertino e 61,2 gramas do matutino), carboidratos (182,1 gramas em relação a 220,1 gramas do turno vespertino e 205,6 gramas do matutino) e proteínas totais (54,5 gramas comparando com 66,2 gramas do 
turno vespertino e 67,5 gramas do matutino) e, também, fibras (9,1 gramas em relação a 9,9 gramas do turno vespertino e 11,2 gramas do matutino), colesterol (172,3 gramas comparando com 244,8 gramas do turno vespertino e 217,8 gramas do matutino) e lipídios insaturados (19,6 gramas baseando-se em 23,3 gramas do turno vespertino e 23,6 gramas do matutino) em relação aos outros turnos. O consumo do percentil de lipídios (\%VCT) foi maior em operadoras do turno noturno baseando-se nos outros turnos de trabalho (31,4\% no turno noturno; $31,2 \%$ do turno vespertino e $30,0 \%$ do turno matutino) (Tabelas 17 e 18).

Em relação à adequação de proteínas (recomendou-se 0,8 gramas de proteínas/kg de peso corporal, sendo para homens: 61,6 gramas para o turno matutino, 61,8 gramas para o turno vespertino e 65,8 gramas para o turno noturno e para mulheres: 52,0 gramas para o turno matutino, 49,3 gramas para o turno vespertino e 47,4 gramas para o turno noturno), os homens do turno vespertino ingeriram, em média, um pouco acima $(187,2 \%)$ do consumido pelos outros turnos $(185,6 \%$ do noturno e $182,8 \%$ do matutino). As mulheres do turno noturno consumiram abaixo (115,0\%) do ingerido pelas operadoras dos outros turnos (134,3\% do turno vespertino e 129,8\% do turno matutino) (Tabela 19). 
Tabela 17 - Média, desvio padrão e valor de significância do consumo de energia e macronutrientes em relação aos turnos de trabalho pelos operadores de telemarketing do gênero masculino. São Paulo, 2002.

\begin{tabular}{|c|c|c|c|c|c|}
\hline Energia e Nutrient & & n & Média & DP & $\mathrm{p}^{1}$ \\
\hline \multicolumn{6}{|l|}{ Energia (kcal) } \\
\hline & Manhã & 12 & 2702,1 & 1074,8 & $0,68^{1}$ \\
\hline & Tarde & 18 & 2635,4 & 610,1 & \\
\hline & Noite & 17 & 2864,2 & 855,1 & \\
\hline \multicolumn{6}{|l|}{ Proteína (g) } \\
\hline & Manhã & 12 & 112,6 & 41,2 & $0,82^{1}$ \\
\hline & Tarde & 18 & 115,7 & 49,6 & \\
\hline & Noite & 17 & 122,1 & 47,7 & \\
\hline \multicolumn{6}{|l|}{ Carboidratos (g) } \\
\hline & Manhã & 12 & 334,0 & 131,1 & $0,95^{1}$ \\
\hline & Tarde & 18 & 329,2 & 90,9 & \\
\hline & Noite & 17 & 339,1 & 96,7 & \\
\hline \multicolumn{6}{|l|}{ Lipídios (g) } \\
\hline & Manhã & 12 & 98,5 & 41,5 & $0,50^{1}$ \\
\hline & Tarde & 18 & 99,8 & 29,2 & \\
\hline & Noite & 17 & 111,2 & 38,4 & \\
\hline \multicolumn{6}{|l|}{ \% de Proteínas do VCT } \\
\hline & Manhã & 12 & 15,5 & 3,3 & $0,50^{1}$ \\
\hline & Tarde & 18 & 17,3 & 6,1 & \\
\hline & Noite & 17 & 17,5 & 5,2 & \\
\hline \multicolumn{6}{|c|}{ \% de Carboidratos do VCT } \\
\hline & Manhã & 12 & 47,3 & 12,0 & $0,98^{2}$ \\
\hline & Tarde & 18 & 47,8 & 8,3 & \\
\hline & Noite & 17 & 47,8 & 6,6 & \\
\hline \multicolumn{6}{|l|}{ \% de Lipídios do VCT } \\
\hline & Manhã & 12 & 30,0 & 6,9 & $0,13^{1}$ \\
\hline & Tarde & 18 & 33,2 & 6,6 & \\
\hline & Noite & 17 & 34,6 & 6,3 & \\
\hline \multicolumn{6}{|l|}{ Lipídios Insaturados (g) } \\
\hline & Manhã & 12 & 42,7 & 21,6 & $0,94^{1}$ \\
\hline & Tarde & 18 & 40,6 & 16,3 & \\
\hline & Noite & 17 & 41,3 & 18,7 & \\
\hline \multicolumn{6}{|l|}{ Colesterol (g) } \\
\hline & Manhã & 12 & 624,1 & 1105,9 & $0,74^{2}$ \\
\hline & Tarde & 18 & 343,6 & 184,6 & \\
\hline & Noite & 17 & 388,6 & 184,4 & \\
\hline \multicolumn{6}{|l|}{ Fibra Alimentar (g) } \\
\hline & Manhã & 12 & 14,6 & 7,6 & $0,91^{2}$ \\
\hline & Tarde & 18 & 15,8 & 9,8 & \\
\hline & Noite & 17 & 13,8 & 4,6 & \\
\hline
\end{tabular}

${ }^{1}$ ANOVA ${ }^{2}$ Teste Kruskal-Wallis 
Tabela 18 - Média, desvio padrão e valor de significância do consumo de energia e macronutrientes em relação aos turnos de trabalho pelos operadores de telemarketing do gênero feminino. São Paulo, 2002.

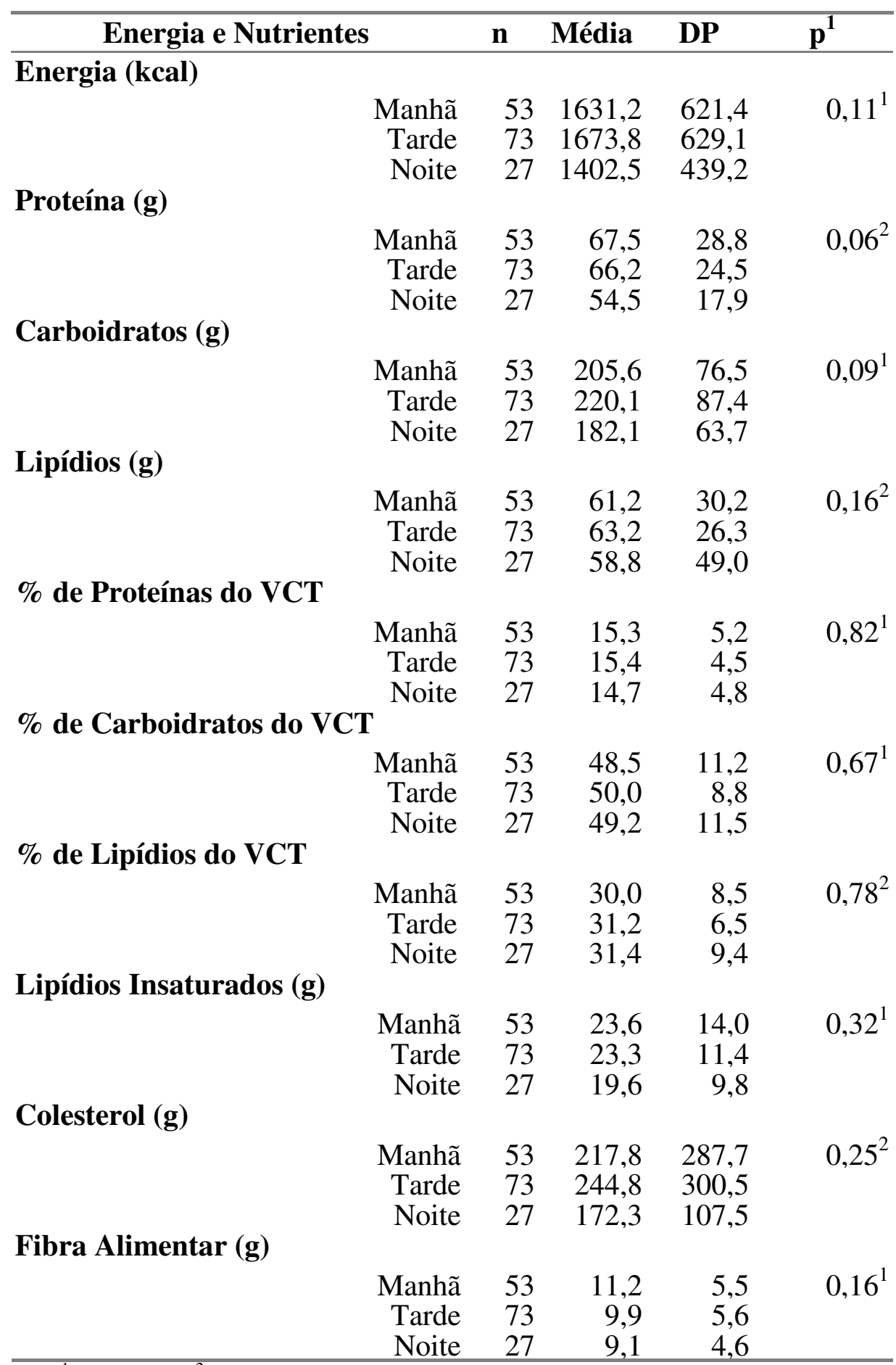

${ }^{1}$ ANOVA ${ }^{2}$ Teste Kruskal-Wallis 
Tabela 19 - Média, desvio padrão e adequação do consumo de energia e proteínas em relação ao gênero e turnos de trabalho dos operadores de telemarketing. São Paulo, 2002.

\begin{tabular}{crrr}
\hline & Média & Desvio Padrão & \% Adequação \\
\hline $\begin{array}{c}\text { Energia (kcal) } \\
\text { Masculino }\end{array}$ & & & \\
Manhã & 2702,1 & 1074,8 & 100 \\
Tarde & 2635,4 & 610,1 & 97,6 \\
Noite & 2864,2 & 855,1 & 106,1 \\
& & & \\
Feminino & & & \\
Manhã & 1631,2 & 621,4 & 77,7 \\
Tarde & 1673,8 & 629,1 & 79,7 \\
Noite & 1402,5 & 439,2 & 66,8 \\
& & & \\
Proteína (g) & & & 182,8 \\
Masculino & & & 187,2 \\
Manhã & 112,6 & 41,2 & 185,6 \\
Tarde & 115,7 & 49,6 & \\
Noite & 122,1 & 47,7 & 129,8 \\
Feminino & & & 115,0 \\
Manhã & 67,5 & 28,8 & \\
Tarde & 66,2 & 24,5 & \\
Noite & 54,5 & 17,9 & \\
\hline
\end{tabular}

\subsubsection{2) O questionário de freqüiência alimentar (QFA)}

A avaliação do consumo de bebidas e alimentos estimulantes do sistema nervoso central (SNC) mostrou maior consumo diário de café, café com leite e refrigerante à base de cola diferindo significantemente entre os turnos $(\mathrm{p}<0,05)$. O turno noturno ingeria mais café $(59,2 \%)$ e bebida à base de cola $(28,6 \%)$. O turno matutino consumia mais café com leite $(59,7 \%)$ e café $(56,9 \%)$ (Figura 5). 
Figura 5 - Porcentagem do consumo diário de bebidas e alimentos estimulantes do sistema nervoso central (SNC) pelos operadores de telemarketing em relação aos turnos de trabalho. São Paulo, 2002.

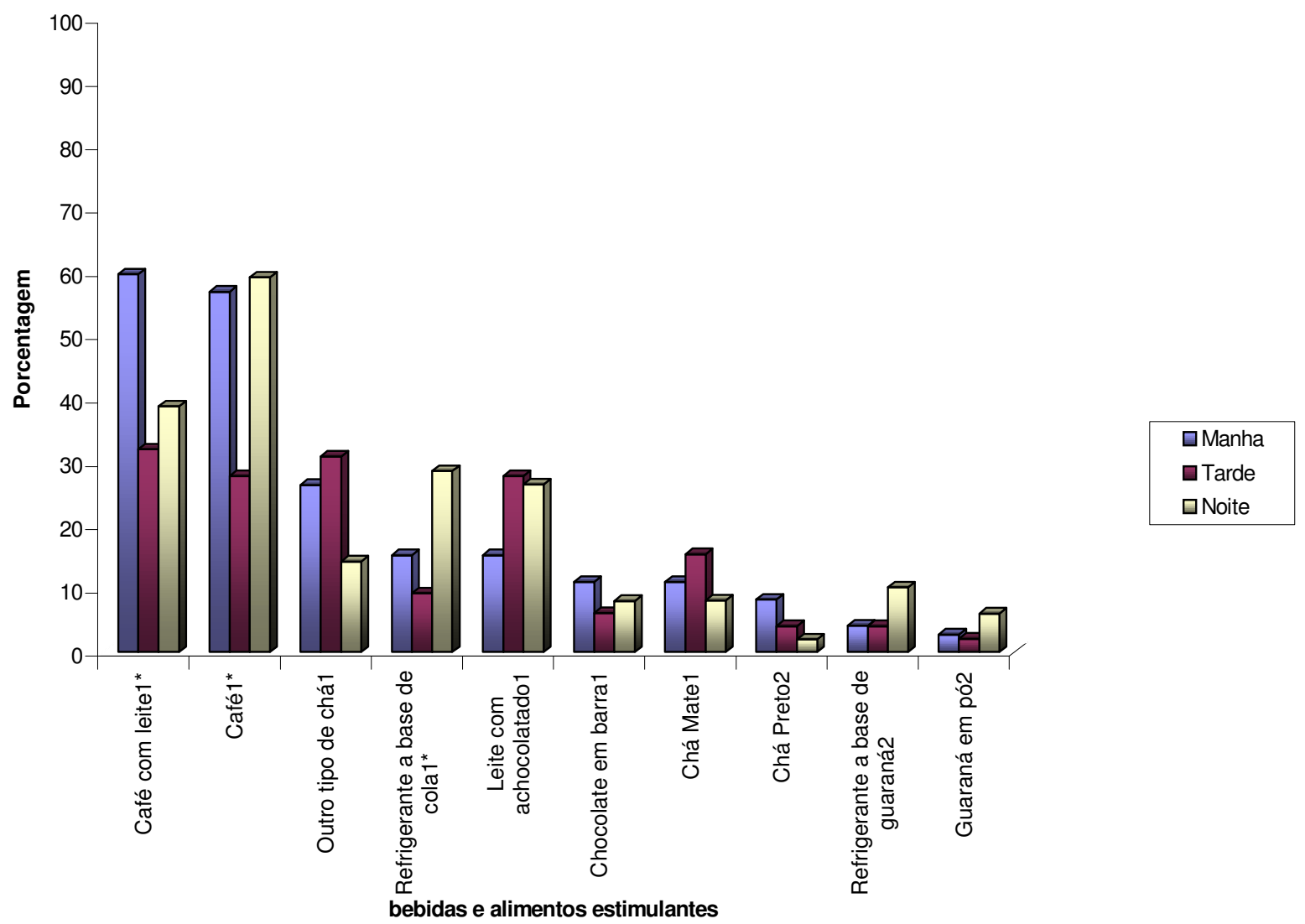

1 Qui-quadrado de Pearson

2 Teste exato de Fisher

$* \mathrm{p}<0,05$

Em relação a quantidade consumida, não houveram diferenças estatisticamente significantes baseando-se nos turnos de trabalho. No turno noturno ingeriam maior quantidade diária de leite com achocolatado $(114,5 \mathrm{ml})$, no turno vespertino refrigerante à base de cola $(115,6 \mathrm{ml})$ e no matutino café $(276,7 \mathrm{ml})$ (Tabela 20). 
Tabela 20 - Média, desvio padrão (DP) e valor de significância do consumo diário de bebidas e alimentos estimulantes do sistema nervoso central pelos operadores em relação aos turnos de trabalho. São Paulo, 2002.

\begin{tabular}{|c|c|c|c|c|c|c|c|}
\hline \multirow{3}{*}{$\begin{array}{c}\text { Bebidas e alimentos } \\
\text { Estimulantes }\end{array}$} & \multicolumn{7}{|c|}{ Turnos } \\
\hline & \multicolumn{2}{|c|}{ Manhã $(n=72)$} & \multicolumn{2}{|c|}{ Tarde $(\mathbf{n}=97)$} & \multicolumn{2}{|c|}{ Noite $(n=49)$} & \multirow[t]{2}{*}{$\mathbf{p}$} \\
\hline & Média & $\mathrm{DP}$ & Média & $\mathrm{DP}$ & Média & DP & \\
\hline Café (ml) & 276,7 & 737,6 & 104,2 & 299,4 & 151,9 & 259,3 & $0,05^{1}$ \\
\hline Café com leite (ml) & 226,0 & 388,2 & 109,2 & 155,3 & 97,5 & 145,5 & $0,36^{2}$ \\
\hline Chá Mate (ml) & 193,0 & 767,1 & 96,4 & 252,2 & 55,4 & 173,2 & $0,09^{2}$ \\
\hline Refrigerante à base de cola (ml) & 159,9 & 256,0 & 115,6 & 198,6 & 192,4 & 262,4 & $0,14^{2}$ \\
\hline Outro tipo de chá (ml) & 159,8 & 430,2 & 36,0 & 112,9 & 55,2 & 150,3 & $0,64^{2}$ \\
\hline Leite com achocolatado (ml) & 148,2 & 245,3 & 107,1 & 165,7 & 114,5 & 294,3 & $0,14^{2}$ \\
\hline Refrigerante à base de guaraná (ml) & 67,7 & 143,4 & 54,3 & 70,7 & 92,3 & 158,6 & $0,64^{1}$ \\
\hline Chá Preto (ml) & 51,4 & 260,6 & 10,8 & 37,3 & 15,6 & 58,5 & $0,98^{2}$ \\
\hline Chocolate em barra $(\mathrm{g})$ & 17,5 & 47,8 & 17,7 & 45,7 & 8,6 & 11,8 & $0,51^{2}$ \\
\hline Guaraná em pó (g) & 0,0 & 0,0 & 0,0 & 0,0 & 0,0 & 0,2 & $0,61^{2}$ \\
\hline
\end{tabular}

${ }^{1}$ ANOVA ${ }^{2}$ Teste Kruskal-Wallis

A avaliação do consumo de lanches identificou diferenças significantes quanto ao número de operadores que consumiam diariamente: bebidas lácteas, sucos de frutas prontos para beber, refrigerantes, biscoitos/salgadinhos e chicletes/balas dietéticos $(\mathrm{p}<0,05)$. Desses alimentos e bebidas, o turno noturno consumia em maior porcentagem diária refrigerantes $(14,3 \%)$ e em menor chicletes/balas dietéticos $(6,1 \%)$, biscoitos/salgadinhos $(18,4 \%)$ e sucos de frutas prontos para beber $(18,4 \%)$ (Figura 6). 
Figura 6 - Porcentagem do consumo diário de lanches pelos operadores de telemarketing em relação aos turnos de trabalho. São Paulo, 2002.

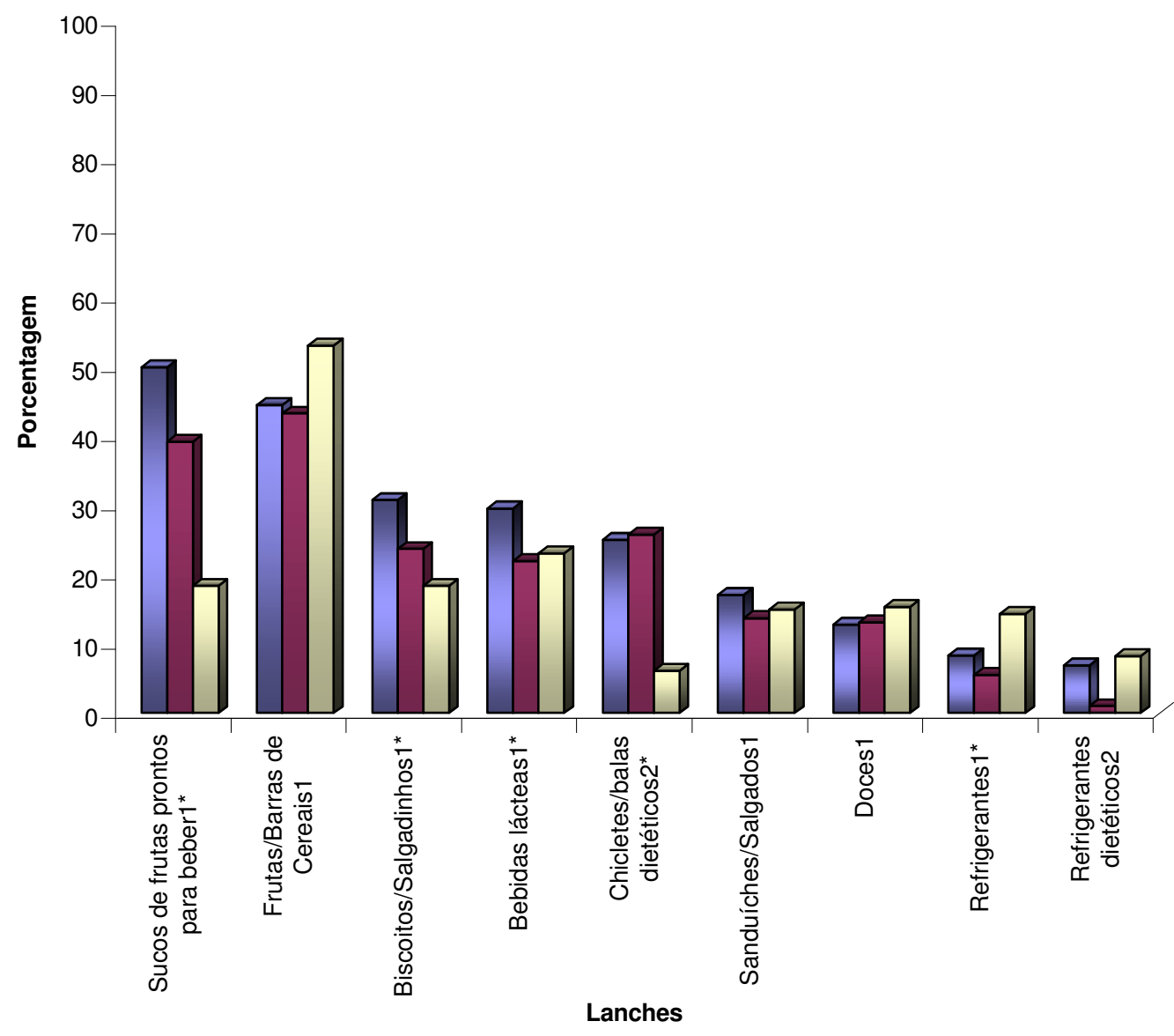

1 Qui-quadrado de Pearson

2 Teste exato de Fisher

$* \mathrm{p}<0,05$

Em relação à quantidade consumida, observam-se diferenças significantes entre os turnos de trabalho e o consumo de: suco de frutas prontos para beber $(p=0,02)$, bebidas lácteas $(p=0,00)$ e chicletes/balas dietéticos $(p=0,02)$. Os operadores do turno noturno consumiam menores quantidades de suco de frutas prontos para beber $(96,5 \mathrm{ml})$ e chicletes/balas dietéticos $(0,5 \mathrm{~g})$ (Tabela 21). 
Tabela 21 - Média, desvio padrão (DP) e valor de significância do consumo diário de lanches pelos operadores de telemarketing em relação aos turnos de trabalho. São Paulo, 2002.

\begin{tabular}{|c|c|c|c|c|c|c|c|}
\hline \multirow[t]{2}{*}{ Lanches } & \multicolumn{2}{|c|}{ Manhã (n=72) } & \multicolumn{2}{|c|}{ Tarde $(n=97)$} & \multicolumn{2}{|c|}{ Noite $(n=49)$} & \multirow[t]{2}{*}{$\mathbf{p}$} \\
\hline & Média & DP & Média & DP & Média & DP & \\
\hline $\begin{array}{l}\text { Sucos de frutas prontos para beber } \\
\qquad(\mathrm{ml})\end{array}$ & 166,2 & 742,0 & 139,9 & 203,1 & 96,5 & 183,3 & $0,02^{2 *}$ \\
\hline Frutas/Barras de Cereais (g) & 161,8 & 201,6 & 113,8 & 130,2 & 106,6 & 120,1 & $0,18^{2}$ \\
\hline Bebidas lácteas (ml) & 117,9 & 122,5 & 80,2 & 63,3 & 73,2 & 111,5 & $0,00^{2} *$ \\
\hline Refrigerantes (ml) & 81,6 & 119,8 & 68,4 & 106,8 & 105,8 & 138,5 & $0,20^{1}$ \\
\hline Refrigerantes dietético (diet) (ml) & 73,4 & 183,2 & 28,1 & 67,8 & 35,7 & 108,5 & $0,11^{2}$ \\
\hline Sanduíches/Salgados (g) & 30,8 & 40,8 & 23,7 & 27,3 & 25,3 & 44,2 & $0,33^{2}$ \\
\hline Salgadinhos/Biscoitos (g) & 15,5 & 20,4 & 17,4 & 25,6 & 21,0 & 50,7 & $0,54^{2}$ \\
\hline Doces $(\mathrm{g})$ & 11,7 & 23,7 & 9,5 & 12,0 & 16,7 & 52,0 & $0,65^{2}$ \\
\hline Chicletes/Balas dietéticos (g) & 1,4 & 4,0 & 1,8 & 5,6 & 0,5 & 2,5 & $0,02^{2 *}$ \\
\hline
\end{tabular}

${ }^{1}$ ANOVA ${ }^{2}$ Teste Kruskal-Wallis * $\mathrm{p}<0,05$

\subsubsection{3) Avaliação antropométrica}

Em homens, não houve diferenças significantes entre os turnos de trabalho quanto ao peso $(\mathrm{p}=0,44)$ e estatura média $(\mathrm{p}=0,83)$. Contudo, os homens do turno noturno eram mais pesados e mais altos em relação aos outros turnos (no noturno peso igual $82,3 \mathrm{~kg}$ e estatura $175,0 \mathrm{~cm}$, no vespertino peso igual a $77,3 \mathrm{~kg}$ e estatura 177,0 $\mathrm{cm}$ e no matutino peso igual a $77,0 \mathrm{~kg}$ e estatura $175,0 \mathrm{~cm}$ ) (Tabela 22).

As mulheres não diferiram estatisticamente quanto ao peso $(\mathrm{p}=0,24)$ e estatura $(\mathrm{p}=0,56)$ em relação aos turnos de trabalho, embora as mulheres do turno noturno fossem mais magras (peso igual a 59,3 $\mathrm{kg}$ contra $61,7 \mathrm{~kg}$ para o turno da tarde e $65,0 \mathrm{~kg}$ 
para o turno da manhã) e mais baixas $(1,56 \mathrm{~cm})$ do que suas companheiras do turno vespertino e matutino (ambas com 1,60 cm) (Tabela 22).

O IMC médio variou significantemente entre os turnos para as mulheres $(\mathrm{p}=0,02)$. As operadoras do turno noturno tinham IMC médio menor do que as trabalhadoras dos outros turnos. Em homens, não foram observadas diferenças significantes entre os turnos de trabalho e o IMC médio ( $\mathrm{p}=0,23)$, apesar de em homens do turno noturno esse indicador ser maior (IMC médio igual a $26,5 \mathrm{~kg} / \mathrm{m}^{2}$ para o turno noturno contra $24,5 \mathrm{~kg} / \mathrm{m}^{2}$ do vespertino e $24,8 \mathrm{~kg} / \mathrm{m}^{2}$ do matutino) (Tabela 22).

Verifica-se maior prevalência de homens do turno noturno obesos $(23,8 \%$ contra $10,5 \%$ do vespertino e não houve casos de obesos no matutino) em relação aos outros turnos, embora não existissem diferenças significantes entre os turnos de trabalho $(\mathrm{p}=0,28)$. Em mulheres, houve diferenças significantes entre a classificação do IMC $(\mathrm{p}=0,03)$ e os turnos de trabalho. As mulheres do turno noturno tinham menor prevalência de sobrepeso ( $12 \%$ à noite contra $20,5 \%$ do turno vespertino e $24,1 \%$ do matutino) e não foi verificada a obesidade nas operadoras do turno noturno. No total da população não foram observadas diferenças estatisticamente significantes $(p=0,05)$ (Tabela 22).

Em relação à CC média, não foram observadas diferenças estatisticamente significantes entre os turnos de trabalho (em homens $p=0,83$, em mulheres $p=0,11$ e em toda a população $\mathrm{p}=0,20$ ). Todavia, homens do turno noturno tiveram $\mathrm{CC}$ média maior em relação aos outros turnos ( $89 \mathrm{~cm}$ contra $86,8 \mathrm{~cm}$ do turno vespertino e $88,1 \mathrm{~cm}$ do turno matutino). As mulheres do turno noturno tiveram CC média menor $(72,8 \mathrm{~cm})$ baseando-se nos turnos vespertino $(74,6 \mathrm{~cm})$ e matutino $(77,5 \mathrm{~cm})$. Além disso, não foram verificadas diferenças estatisticamente significantes entre a classificação da CC e turnos de trabalho para homens $(\mathrm{p}=0,66)$, mulheres $(\mathrm{p}=0,28)$ e todos os indivíduos $(p=0,26)$. Os operadores do gênero masculino do turno noturno apresentaram maior número de trabalhadores com risco muito alto para doenças crônicas degenerativas nãotransmissíveis associadas à obesidade $(19,0 \%)$. As operadoras do turno noturno estavam com menor proporção de mulheres com risco muito aumentado baseando-se nos outros turnos (2,1\% contra 9,0\% do turno vespertino e $14,3 \%$ do turno matutino) (Tabela 22). 
Tabela 22 - Características antropométricas dos operadores de telemarketing em relação ao gênero e turnos de trabalho em número e porcentagem. São Paulo, 2002.

\begin{tabular}{|c|c|c|c|c|c|c|c|c|c|}
\hline & \multicolumn{3}{|c|}{ Masculino } & \multicolumn{3}{|c|}{ Feminino } & \multicolumn{3}{|c|}{ Total } \\
\hline & $\begin{array}{c}\text { Manhã } \\
(\mathrm{n}=14)\end{array}$ & $\begin{array}{l}\text { Tarde } \\
(\mathrm{n}=19)\end{array}$ & $\begin{array}{l}\text { Noite } \\
(n=21)\end{array}$ & $\begin{array}{l}\text { Manhã } \\
(\mathrm{n}=56)\end{array}$ & $\begin{array}{c}\text { Tarde } \\
(\mathrm{n}=78)\end{array}$ & $\begin{array}{l}\text { Noite } \\
(n=26)\end{array}$ & $\begin{array}{l}\text { Manhã } \\
(\mathrm{n}=70)\end{array}$ & $\begin{array}{l}\text { Tarde } \\
(\mathrm{n}=97)\end{array}$ & $\begin{array}{l}\text { Noite } \\
(\mathrm{n}=47)\end{array}$ \\
\hline $\begin{array}{l}\text { Peso médio (kg) } \\
\text { (DP) } \\
\text { p entre os turnos }\end{array}$ & $\begin{array}{c}77,0 \\
(12,4)\end{array}$ & $\begin{array}{c}77,3 \\
(16,4)\end{array}$ & $\begin{array}{c}82,3 \\
(13,6) \\
0,44^{1}\end{array}$ & $\begin{array}{c}65,0 \\
(14,6)\end{array}$ & $\begin{array}{c}61,7 \\
(14,0)\end{array}$ & $\begin{array}{l}59,3 \\
(8,2) \\
0,24^{2}\end{array}$ & $\begin{array}{c}67,4 \\
(14,9)\end{array}$ & $\begin{array}{c}64,7 \\
(15,6)\end{array}$ & $\begin{array}{c}69,4 \\
(15,9) \\
0,20^{1}\end{array}$ \\
\hline $\begin{array}{l}\text { Estatura média(m) } \\
\text { (DP) } \\
\text { p entre os turnos }\end{array}$ & $\begin{array}{l}1,75 \\
(0,1)\end{array}$ & $\begin{array}{l}1,77 \\
(0,1)\end{array}$ & $\begin{array}{l}1,75 \\
(0,1) \\
0,83^{2}\end{array}$ & $\begin{array}{l}1,60 \\
(0,1)\end{array}$ & $\begin{array}{l}1,60 \\
(0,1)\end{array}$ & $\begin{array}{l}1,56 \\
(0,3) \\
0,56^{2}\end{array}$ & $\begin{array}{l}1,63 \\
(0,1)\end{array}$ & $\begin{array}{l}1,64 \\
(0,1)\end{array}$ & $\begin{array}{l}1,64 \\
(0,2) \\
0,17^{1}\end{array}$ \\
\hline $\begin{array}{l}\text { IMC médio }\left(\mathrm{kg} / \mathrm{m}^{2}\right) \\
\text { (DP) } \\
\text { p entre os turnos }\end{array}$ & $\begin{array}{l}24,8 \\
(3,1)\end{array}$ & $\begin{array}{l}24,5 \\
(4,4)\end{array}$ & $\begin{array}{l}26,5 \\
(3,9) \\
0,23^{1}\end{array}$ & $\begin{array}{l}25,1 \\
(4,7)\end{array}$ & $\begin{array}{l}23,7 \\
(4,8)\end{array}$ & $\begin{array}{c}22,6 \\
(3,0) \\
0,02^{1} *\end{array}$ & $\begin{array}{l}25,1 \\
(4,5)\end{array}$ & $\begin{array}{l}23,7 \\
(4,6)\end{array}$ & $\begin{array}{l}24,4 \\
(3,4) \\
0,20^{1}\end{array}$ \\
\hline $\begin{array}{l}\text { CC média (cm) } \\
\text { (DP) } \\
\text { p entre os turnos }\end{array}$ & $\begin{array}{l}88,1 \\
(9,9)\end{array}$ & $\begin{array}{c}86,8 \\
(12,7)\end{array}$ & $\begin{array}{c}89,0 \\
(12,3) \\
0,83^{1}\end{array}$ & $\begin{array}{c}77,5 \\
(10,9)\end{array}$ & $\begin{array}{c}74,6 \\
(10,9)\end{array}$ & $\begin{array}{l}72,8 \\
(8,3) \\
0,11^{1}\end{array}$ & $\begin{array}{c}79,6 \\
(11,5)\end{array}$ & $\begin{array}{c}76,9 \\
(12,2)\end{array}$ & $\begin{array}{c}79,7 \\
(13,1) \\
0,26^{1}\end{array}$ \\
\hline IMC $\left(\mathrm{kg} / \mathrm{m}^{2}\right)$ & & & & & & & & & \\
\hline $\begin{array}{l}\text { Desnutridos/Normais } \mathrm{n} \\
(\%) \\
\text { Sobrepeso } \mathrm{n} \\
(\%)\end{array}$ & $\begin{array}{c}7 \\
(50,0) \\
7 \\
(50,0)\end{array}$ & $\begin{array}{c}12 \\
(63,2) \\
5 \\
(26,3)\end{array}$ & $\begin{array}{c}9 \\
(42,9) \\
7 \\
(33,3)\end{array}$ & $\begin{array}{c}37 \\
(62,5) \\
14 \\
(24,1)\end{array}$ & $\begin{array}{c}57 \\
(73,1) \\
16 \\
(20,5)\end{array}$ & $\begin{array}{c}7 \\
(12,1) \\
4 \\
(12,0)\end{array}$ & $\begin{array}{c}42 \\
(60,0) \\
21 \\
(30,0)\end{array}$ & $\begin{array}{c}69 \\
(71,2) \\
21 \\
(21,6)\end{array}$ & $\begin{array}{c}31 \\
(67,4) \\
11 \\
(21,7)\end{array}$ \\
\hline $\begin{array}{l}\text { Obesos } n \\
(\%) \\
\text { p entre os turnos }\end{array}$ & - & $\begin{array}{c}2 \\
(10,5)\end{array}$ & $\begin{array}{c}5 \\
(23,8) \\
0,28^{3}\end{array}$ & $\begin{array}{c}7 \\
(12,1)\end{array}$ & $\begin{array}{c}5 \\
(6,4)\end{array}$ & $0,03^{3} *$ & $\begin{array}{c}7 \\
(10,0)\end{array}$ & $\begin{array}{c}7 \\
(7,2)\end{array}$ & $\begin{array}{c}5 \\
(10,9) \\
0,05^{3}\end{array}$ \\
\hline $\mathrm{CC}(\mathrm{cm})$ & & & & & & & & & \\
\hline $\begin{array}{l}\text { Normais } n \\
(\%)\end{array}$ & $\begin{array}{c}9 \\
(64,3)\end{array}$ & $\begin{array}{c}15 \\
(78,9)\end{array}$ & $\begin{array}{c}15 \\
(31,9)\end{array}$ & $\begin{array}{c}37 \\
(66,1)\end{array}$ & $\begin{array}{c}62 \\
(79,5)\end{array}$ & $\begin{array}{c}20 \\
(42,5)\end{array}$ & $\begin{array}{c}46 \\
(65,7)\end{array}$ & $\begin{array}{c}77 \\
(79,4)\end{array}$ & $\begin{array}{c}35 \\
(74,5)\end{array}$ \\
\hline $\begin{array}{l}\text { Aumento n } \\
(\%)\end{array}$ & $\begin{array}{c}3 \\
(21,4)\end{array}$ & $\begin{array}{c}1 \\
(1,3)\end{array}$ & $\begin{array}{c}2 \\
(4,2)\end{array}$ & $\begin{array}{c}11 \\
(19,6)\end{array}$ & $\begin{array}{c}9 \\
(11,5)\end{array}$ & $\begin{array}{c}5 \\
(10,6)\end{array}$ & $\begin{array}{c}14 \\
(20,0)\end{array}$ & $\begin{array}{c}10 \\
(10,3)\end{array}$ & $\begin{array}{c}7 \\
(14,9)\end{array}$ \\
\hline $\begin{array}{l}\text { Muito aumentado } n \\
(\%) \\
\text { p entre os turnos }\end{array}$ & $\begin{array}{c}2 \\
(14,3)\end{array}$ & $\begin{array}{c}2 \\
(9,6)\end{array}$ & $\begin{array}{c}4 \\
(8,5) \\
0,66^{3}\end{array}$ & $\begin{array}{c}8 \\
(14,3)\end{array}$ & $\begin{array}{c}7 \\
(9,0)\end{array}$ & $\begin{array}{c}1 \\
(2,1) \\
0,28^{3}\end{array}$ & $\begin{array}{c}10 \\
(14,3)\end{array}$ & $\begin{array}{c}9 \\
(9,3)\end{array}$ & $\begin{array}{c}5 \\
(10,6) \\
0,33^{4}\end{array}$ \\
\hline
\end{tabular}

Os dados do IMC foram analisados em gênero, turnos e faixa etária e comparados com os dados da PNSN (COITINHO et al. 1989). Desta forma, utilizaram- 
se os dados de homens e mulheres da população do Sudeste urbano compreendidos nas faixas etárias entre 18 e 24 anos, 25 e 34 anos, 35 e 44 anos e 45 e 54 anos.

Verificaram-se, em homens do turno noturno, maiores prevalências de obesidade $(6,3 \%, 6,5 \%$ e 28,6\%) em todas as faixas etárias em relação à PNSN $(2,1 \%, 4,7 \%$ e 7,4 e 8,9\%). Na faixa etária entre 19 e 24 anos, em homens do turno vespertino, foi verificada maior prevalência de obesidade $(12,5 \%)$ do que a PNSN $(2,1 \%)$. Nos outros grupos etários verificaram-se prevalências mais baixas do que a observada na PNSN (Tabela 23).

Em relação à circunferência da cintura, observa-se que 6,3\% dos homens jovens do turno noturno (19-24 anos) e 18,3\% do turno vespertino apresentavam risco muito elevado para desenvolver doenças crônicas degenerativas não-transmissíveis associadas à obesidade. Além disso, em homens na faixa etária maior igual a 35 anos, detectou-se risco muito aumentado, somente em operadores do turno noturno $(28,6 \%)$ (Tabela 23).

Em mulheres na faixa etária entre 19 e 24 anos, operadoras do turno noturno apresentaram risco muito aumentado $(4,5 \%)$ para doenças crônicas degenerativas nãotransmissívies associadas à obesidade. Em mulheres do turno vespertino, verificaram-se maiores prevalências de risco muito aumentado nas faixas etárias entre 25 e 34 anos $(7,0 \%)$ e maior igual a 35 anos (10,8\%) (Tabela 23). 
Tabela 23 - Distribuição em número e porcentagem do índice de massa corporal e circunferência da cintura, segundo faixas etárias, gênero e turnos de trabalho. São Paulo, 2002.

\begin{tabular}{|c|c|c|c|c|c|c|c|c|c|c|c|c|c|c|c|c|c|c|}
\hline & \multicolumn{9}{|c|}{ IMC } & \multicolumn{9}{|c|}{$\mathrm{CC}$} \\
\hline & \multicolumn{3}{|c|}{ Manhã $(n=70)$} & \multicolumn{3}{|c|}{ Tarde $(n=97)$} & \multicolumn{3}{|c|}{ Noite $(n=47)$} & \multicolumn{3}{|c|}{ Manhã (n=70) } & \multicolumn{3}{|c|}{ Tarde $(n=97)$} & \multicolumn{3}{|c|}{ Noite $(n=47)$} \\
\hline & $\begin{array}{l}\mathrm{D} / \mathrm{N} \\
\mathrm{n}(\%)\end{array}$ & $\begin{array}{c}\mathrm{S} \\
\mathrm{n}(\%)\end{array}$ & $\begin{array}{c}\mathrm{O} \\
\mathrm{n}(\%)\end{array}$ & $\begin{array}{c}\mathrm{D} / \mathrm{N} \\
\mathrm{n}(\%)\end{array}$ & $\begin{array}{c}\mathrm{S} \\
\mathrm{n}(\%)\end{array}$ & $\begin{array}{c}\mathrm{O} \\
\mathrm{n}(\%)\end{array}$ & $\begin{array}{c}\mathrm{D} / \mathrm{N} \\
\mathrm{n}(\%)\end{array}$ & $\begin{array}{c}\mathrm{S} \\
\mathrm{n}(\%)\end{array}$ & $\begin{array}{c}\mathrm{O} \\
\mathrm{n}(\%)\end{array}$ & $\begin{array}{c}\mathrm{N} \\
\mathrm{n}(\%)\end{array}$ & $\begin{array}{c}\mathrm{A} \\
\mathrm{n}(\%)\end{array}$ & $\begin{array}{c}\text { MA } \\
\text { n (\%) }\end{array}$ & $\begin{array}{c}\mathrm{N} \\
\mathrm{n}(\%)\end{array}$ & $\begin{array}{c}\mathrm{A} \\
\mathrm{n}(\%)\end{array}$ & $\begin{array}{l}\text { MA } \\
\text { n (\%) }\end{array}$ & $\begin{array}{c}\mathrm{N} \\
\mathrm{n}(\%)\end{array}$ & $\begin{array}{c}\mathrm{A} \\
\mathrm{n}(\%)\end{array}$ & $\begin{array}{c}\text { MA } \\
\mathrm{n}(\%)\end{array}$ \\
\hline Homens & & & & & & & & & & & & & & & & & & \\
\hline $\begin{array}{l}19-24 \\
(\mathrm{n}=16)\end{array}$ & $\begin{array}{c}3 \\
(18,6)\end{array}$ & - & - & $\begin{array}{c}6 \\
(37,5)\end{array}$ & $\begin{array}{c}1 \\
(6,3)\end{array}$ & $\begin{array}{c}2 \\
(12,5)\end{array}$ & $\begin{array}{c}2 \\
(12,5)\end{array}$ & $\begin{array}{c}1 \\
(6,3)\end{array}$ & $\begin{array}{c}1 \\
(6,3)\end{array}$ & $\begin{array}{c}3 \\
(18,6)\end{array}$ & - & - & $\begin{array}{c}6 \\
(37,5)\end{array}$ & - & $\begin{array}{c}3 \\
(18,6)\end{array}$ & $\begin{array}{c}3 \\
(18,6)\end{array}$ & - & $\begin{array}{c}1 \\
(6,3)\end{array}$ \\
\hline $\begin{array}{l}25-34 \\
(n=31)\end{array}$ & $\begin{array}{c}3 \\
(9.7)\end{array}$ & $\begin{array}{c}6 \\
(19.3)\end{array}$ & - & $\begin{array}{c}4 \\
(12,9)\end{array}$ & $\begin{array}{c}4 \\
(129)\end{array}$ & - & $\begin{array}{c}7 \\
(22.6)\end{array}$ & $\begin{array}{c}5 \\
(16.1)\end{array}$ & $\begin{array}{c}2 \\
(6.5)\end{array}$ & $\begin{array}{c}5 \\
(16,1)\end{array}$ & $\begin{array}{c}2 \\
(6.5)\end{array}$ & $\begin{array}{c}2 \\
(6,5)\end{array}$ & $\begin{array}{c}7 \\
(22,6)\end{array}$ & $\begin{array}{c}1 \\
(3,2)\end{array}$ & - & $\begin{array}{c}12 \\
(38,7)\end{array}$ & $\begin{array}{c}1 \\
(3,2)\end{array}$ & $\begin{array}{c}1 \\
(3.2)\end{array}$ \\
\hline $\begin{array}{l}35 \text { ou mais } \\
(\mathrm{n}=7)\end{array}$ & $\begin{array}{c}1 \\
(14,3)\end{array}$ & $\begin{array}{c}1 \\
(14,3)\end{array}$ & - & $\begin{array}{c}2 \\
(28,6)\end{array}$ & - & - & - & $\begin{array}{c}1 \\
(14,3)\end{array}$ & $\begin{array}{c}2 \\
(28,6)\end{array}$ & $\begin{array}{c}1 \\
(14,3)\end{array}$ & $\begin{array}{c}1 \\
(14,3)\end{array}$ & - & $\begin{array}{c}2 \\
(28,6)\end{array}$ & - & - & - & $\begin{array}{c}1 \\
(14,3)\end{array}$ & $\begin{array}{c}2 \\
(28,6)\end{array}$ \\
\hline Mulheres & & & & & & & & & & & & & & & & & & \\
\hline $\begin{array}{l}19-24 \\
(\mathrm{n}=66)\end{array}$ & $\begin{array}{c}15 \\
(22,8)\end{array}$ & $\begin{array}{c}2 \\
(3,0)\end{array}$ & - & $\begin{array}{c}29 \\
(43,9)\end{array}$ & $\begin{array}{c}9 \\
(13,7)\end{array}$ & $\begin{array}{c}2 \\
(3,0)\end{array}$ & $\begin{array}{c}9 \\
(13,6)\end{array}$ & - & - & $\begin{array}{c}9 \\
(13,6)\end{array}$ & - & - & $\begin{array}{c}16 \\
(24,3)\end{array}$ & $\begin{array}{c}1 \\
(1,5)\end{array}$ & - & $\begin{array}{c}33 \\
(50,0)\end{array}$ & $\begin{array}{c}4 \\
(6,1)\end{array}$ & $\begin{array}{c}3 \\
(4,5)\end{array}$ \\
\hline $\begin{array}{l}25-34 \\
(n=57)\end{array}$ & $\begin{array}{c}10 \\
(17,6)\end{array}$ & $\begin{array}{c}8 \\
(14,0)\end{array}$ & $\begin{array}{c}4 \\
(7,0)\end{array}$ & $\begin{array}{c}23 \\
(40,3)\end{array}$ & $\begin{array}{c}4 \\
(7,0)\end{array}$ & $\begin{array}{c}1 \\
(1,8)\end{array}$ & $\begin{array}{c}6 \\
(10,5)\end{array}$ & $\begin{array}{c}1 \\
(1,8)\end{array}$ & - & $\begin{array}{c}6 \\
(10,5)\end{array}$ & $\begin{array}{c}1 \\
(1,8)\end{array}$ & - & $\begin{array}{c}12 \\
(21,0)\end{array}$ & $\begin{array}{c}6 \\
(10,5)\end{array}$ & $\begin{array}{c}4 \\
(7,0)\end{array}$ & $\begin{array}{c}25 \\
(43,9)\end{array}$ & $\begin{array}{c}2 \\
(3,5)\end{array}$ & $\begin{array}{c}1 \\
(1,8)\end{array}$ \\
\hline $\begin{array}{l}35 \text { ou mais } \\
(\mathrm{n}=37)\end{array}$ & $\begin{array}{c}10 \\
(27,0)\end{array}$ & $\begin{array}{c}4 \\
(10,8)\end{array}$ & $\begin{array}{c}3 \\
(8,1)\end{array}$ & $\begin{array}{c}5 \\
(13,5)\end{array}$ & $\begin{array}{c}3 \\
(8,1)\end{array}$ & $\begin{array}{c}2 \\
(5,4)\end{array}$ & $\begin{array}{c}6 \\
(16,3)\end{array}$ & $\begin{array}{c}3 \\
(8,1)\end{array}$ & $\begin{array}{c}1 \\
(2,7)\end{array}$ & $\begin{array}{c}5 \\
(13,5)\end{array}$ & $\begin{array}{c}4 \\
(10,8)\end{array}$ & $\begin{array}{c}1 \\
(2,7)\end{array}$ & $\begin{array}{c}9 \\
(24,4)\end{array}$ & $\begin{array}{c}4 \\
(10,8)\end{array}$ & $\begin{array}{c}4 \\
(10,8)\end{array}$ & $\begin{array}{c}4 \\
(10,8)\end{array}$ & $\begin{array}{c}3 \\
(8,1)\end{array}$ & $\begin{array}{c}3 \\
(8,1)\end{array}$ \\
\hline Total & & & & & & & & & & & & & & & & & & \\
\hline $\begin{array}{l}19-24 \\
(\mathrm{n}=82)\end{array}$ & $\begin{array}{c}18 \\
(21,9)\end{array}$ & $\begin{array}{c}2 \\
(2,4)\end{array}$ & - & $\begin{array}{c}35 \\
(42,7)\end{array}$ & $\begin{array}{c}10 \\
(12,2)\end{array}$ & $\begin{array}{c}4 \\
(4,9)\end{array}$ & $\begin{array}{c}11 \\
(13,4)\end{array}$ & $\begin{array}{c}1 \\
(1,2)\end{array}$ & $\begin{array}{c}1 \\
(1,2)\end{array}$ & $\begin{array}{c}12 \\
(14,7)\end{array}$ & - & - & $\begin{array}{c}22 \\
(26,8)\end{array}$ & $\begin{array}{c}1 \\
(1,2)\end{array}$ & $\begin{array}{c}3 \\
(3,6)\end{array}$ & $\begin{array}{c}36 \\
(43,9)\end{array}$ & $\begin{array}{c}4 \\
(4,9)\end{array}$ & $\begin{array}{c}4 \\
(4,9)\end{array}$ \\
\hline $\begin{array}{l}25-34 \\
(\mathrm{n}=88)\end{array}$ & $\begin{array}{c}13 \\
(14,8)\end{array}$ & $\begin{array}{c}14 \\
(15,9)\end{array}$ & $\begin{array}{c}4 \\
(4,5)\end{array}$ & $\begin{array}{c}27 \\
(30,8)\end{array}$ & $\begin{array}{c}8 \\
(9,1)\end{array}$ & $\begin{array}{c}1 \\
(1,1)\end{array}$ & $\begin{array}{c}13 \\
(14,8)\end{array}$ & $\begin{array}{c}6 \\
(6,8)\end{array}$ & $\begin{array}{c}2 \\
(2,2)\end{array}$ & $\begin{array}{c}11 \\
(12,5)\end{array}$ & $\begin{array}{c}3 \\
(3,4)\end{array}$ & $\begin{array}{c}2 \\
(22,7)\end{array}$ & $\begin{array}{c}19 \\
(21,6)\end{array}$ & $\begin{array}{c}7 \\
(8,0)\end{array}$ & $\begin{array}{c}4 \\
(4,5)\end{array}$ & $\begin{array}{c}37 \\
(42,0)\end{array}$ & $\begin{array}{c}3 \\
(3,4)\end{array}$ & $\begin{array}{c}2 \\
(22,7)\end{array}$ \\
\hline $\begin{array}{l}35 \text { ou mais } \\
(\mathrm{n}=44)\end{array}$ & $\begin{array}{c}11 \\
(25,0)\end{array}$ & $\begin{array}{c}5 \\
(11,4)\end{array}$ & $\begin{array}{c}3 \\
(6,8)\end{array}$ & $\begin{array}{c}7 \\
(15,9)\end{array}$ & $\begin{array}{c}3 \\
(6,8)\end{array}$ & $\begin{array}{c}2 \\
(4,5)\end{array}$ & $\begin{array}{c}6 \\
(13,6)\end{array}$ & $\begin{array}{c}4 \\
(9,0)\end{array}$ & $\begin{array}{c}3 \\
(6,8)\end{array}$ & $\begin{array}{c}6 \\
(13,6)\end{array}$ & $\begin{array}{c}5 \\
(11,4)\end{array}$ & $\begin{array}{c}1 \\
(2,3)\end{array}$ & $\begin{array}{c}11 \\
(25,0)\end{array}$ & $\begin{array}{c}4 \\
(9,0)\end{array}$ & $\begin{array}{c}4 \\
(9,0)\end{array}$ & $\begin{array}{c}4 \\
(9,0)\end{array}$ & $\begin{array}{c}4 \\
(9,0)\end{array}$ & $\begin{array}{c}5 \\
(11,4)\end{array}$ \\
\hline
\end{tabular}




\section{5) DISCUSSÃO}

Esse estudo verificou que os operadores eram formados, em sua maioria, por mulheres jovens, concentradas na faixa etária entre 19 e 24 anos e os homens estavam na faixa etária entre 30 e 34 anos. O gênero masculino predominava no turno noturno. Os trabalhadores foram caracterizados por serem solteiros e possuírem o ensino médio completo ou o ensino superior incompleto. Esse perfil corresponde ao da publicação do Sindicato dos Operadores de Telemarketing (SINTRATEL 2001). Além disso, a população caracterizou-se por quase metade dos indivíduos consumir bebidas alcoólicas e menos que um quinto fumar.

Ao identificar o estado nutricional da população, observou-se que os operadores do gênero masculino apresentaram maior prevalência de obesidade do que a registrada na PNSN em todas as faixas etárias. Em mulheres, na faixa etária superior ou igual a 25 anos houve maior porcentagem de obesidade em relação à pesquisa nacional. Na faixa etária entre 19 e 24 anos identificou-se maior número de operadoras com sobrepeso do que a verificada pela PNSN. As prevalências de sobrepeso e obesidade identificadas nessa pesquisa, ao serem comparadas com as de uma população trabalhadora, indicam prevalências mais elevadas tendo em vista as faixas etárias jovens dos operadores. ELL e cols. (1999) identificaram em trabalhadores, compreendidos na faixa etária entre 22 e 59 anos, que $36 \%$ dos homens e $17 \%$ das mulheres estavam com sobrepeso. $7 \%$ dos homens e menos que $1 \%$ das mulheres estavam obesos. Além disso, identificou-se que mais da metade da população ganhou 5 ou mais quilos de peso na vida adulta.

Os resultados da circunferência da cintura mostram a mesma tendência da identificada pelo IMC. Verificou-se alta porcentagem de homens com risco muito aumentado para doenças crônicas não-transmissíveis associadas à obesidade e em mulheres observou-se maior prevalência de risco aumentado. Ao analisar os dados por faixa etária, nota-se em homens jovens maior prevalência de indivíduos com risco muito elevado para doenças crônicas associadas à obesidade. Em mulheres, verifica-se aumento do risco com o decorrer da idade.

Deve-se ter em mente que a obesidade é fator preditivo de doença cardiovascular (DCV) futura, pois o risco relativo de indivíduos com IMC $>30 \mathrm{~kg} / \mathrm{m}^{2}$ é 2-3 vezes 
maior quando comparado ao IMC entre 25 e $30 \mathrm{~kg} / \mathrm{m}^{2}$ (SEIDELL 2000). A OMS cita o sobrepeso e a obesidade como fatores de risco de aumento da morbidade e mortalidade (WHO 1995). Além disso, sabe-se que a localização abdominal da gordura (obesidade central) se mostra mais associada a distúrbios metabólicos, como resistência à insulina e risco cardiovascular (WHO 2000).

Uma possível explicação para as maiores taxas de obesidade e sobrepeso nessa população é o aumento da obesidade no país, principalmente em homens. Segundo MONTEIRO e cols. (2000), ao estudarem a prevalência de obesidade no país no período de 1989 (PNSN) a 1997 (Pesquisa sobre padrões de vida - PPV), em homens houve aumento em torno de $50 \%$ (de 4,7\% para 6,9\%), bem como o avanço do IMC médio para uma unidade (de 23,3 para $24,3 \mathrm{~kg} / \mathrm{m}^{2}$ ). As mulheres tiveram um aumento em meia unidade do IMC médio e elevação da taxa de obesidade em meio percentual.

O aumento da obesidade no país e no mundo nas duas últimas décadas, segundo HILL e cols. (2000), poderia ser devido a fatores ambientais, principalmente em indivíduos suscetíveis. Entre os fatores ambientais, cita-se a farta disponibilidade de alimentos de alta densidade energética e gordurosa, estilo de vida sedentário das sociedades modernas e fatores dietéticos. Além disso, a urbanização da sociedade, mudanças na estrutura do trabalho e aumento da renda poderiam influenciar o ganho de peso da população em geral (POPKIN e DOAK 1998).

Neste estudo, ao observar as tarefas dos operadores de telemarketing verificouse que o trabalho era predominantemente sedentário, isto é, realizavam tarefas que despendiam pouca energia. O IBGE (BRASIL 1993) cita que o aumento do setor terceário gerou o aumento de profissões que despendem pouca energia no trabalho, ou seja, são caracterizadas por serem atividades leves. Possivelmente, as condições do trabalho poderiam interferir no ganho de peso dos operadores, pois quase metade da população estava ganhando peso em função do trabalho e o principal motivo atribuído pelos operadores foi o trabalho ser realizado quase todo o tempo sentado. Segundo GRANDJEAN (1998) os trabalhadores que desenvolvem atividades sedentárias teriam uma tendência a comer mais do que necessitariam durante o dia e, portanto, poderiam ter excesso de peso.

A forma de organização do trabalho poderia também influenciar nas taxas de sobrepeso e obesidade. As tarefas como atender chamadas, acolher reclamações e 
oferecer bens e produtos exigiam intensa concentração mental, pois havia muitas informações a serem processadas, alto nível de responsabilidade e diferentes demandas de ligações que chegavam às centrais. Outras tarefas, como atender elevado número de ligações sem interrupções, ser requisitado a atender rapidamente, acolher as ligações de forma adequada e monitoramento das chamadas dificultavam o trabalho, contribuindo para agravar o sistema neuropsíquico (RAAB e ROCHA 2002; SINTRATEL 2001). Cita-se também que mais de um quarto dos operadores referiu alterar o consumo alimentar em função da ansiedade do trabalho, o que poderia contribuir para o aumento do IMC. Desta forma, esses fatores de estresse no trabalho poderiam influenciar no consumo alimentar e no estado nutricional dos indivíduos, pois segundo LAITINEN e cols. (2002) certos indivíduos em situações estressantes utilizariam a alimentação ou bebidas para sentir-se melhor, e a alimentação nessas situações seria rica em açúcares e gorduras, o que poderia favorecer o ganho de peso. No estudo citado, o estresse estaria associado à obesidade, principalmente em mulheres.

Outra característica do trabalho analisado foram os turnos. A classificação e a média do IMC em homens não apresentaram diferenças estatisticamente significantes em relação aos turnos de trabalho. Porém, observou-se que homens do turno noturno estavam com maior prevalência de obesidade em relação aos outros turnos, bem como possuíam IMC médio maior e apresentaram taxas de obesidade mais elevadas comparando-se com a PNSN em todas as faixas etárias. Nas mulheres identifica-se quadro oposto: as operadoras do turno noturno diferiram significantemente entre os turnos vespertino e matutino na classificação do IMC e no IMC médio, sendo que apresentavam maior número de mulheres com IMC normal e menor com sobrepeso, bem como o IMC médio das operadoras do turno noturno apresentava menor valor. Não foram identificadas diferenças significantes entre $\mathrm{CC}$ e turnos de trabalho. $\mathrm{O}$ risco aumentado para doenças crônicas associadas à obesidade foi mais prevalente em homens do turno matutino e noturno e em mulheres verificou-se menor número de casos. Ressalta-se que em indivíduos jovens (19-24 anos) do turno noturno observou-se risco muito aumentado para doenças crônicas degenerativas não-transmissíveis associadas à obesidade. Outro dado relativo à obesidade e turnos é que cerca de um terço dos operadores referiram ganhar peso em função dos turnos de trabalho, portanto, 
o aumento de peso verificado, sobretudo em homens do turno noturno, poderia estar relacionado com os horários de trabalho.

Ao se comparar esse estudo com NAKAMURA e cols. (1997), identifica-se situação semelhante à verificada em homens. Esses autores também não encontraram diferenças estatisticamente significantes entre homens japoneses do turno diurno e de 3 e 2 turnos rodiziantes, incluindo turno noturno, sendo que os trabalhadores em turnos tinham IMC médio maior. Outra pesquisa, também concorda com os resultados obtidos. THIAGO (2000) verificou em estudo transversal que em enfermeiros brasileiros do turno noturno de um hospital em São Paulo, com jornada de trabalho de 12 horas de ambos os sexos (idade média para os homens $=41,3$ anos e para mulheres 41,9 anos), a proporção de homens com risco aumentado foi similar à dessa pesquisa.

Em termos de consumo médio de energia, em homens a porcentagem da adequação calórica alcançou $100 \%$ das necessidades e em mulheres $77 \%$. A pesquisa de orçamento familiar (POF) de 1996/1997 verificou que na área metropolitana de São Paulo a porcentagem de adequação de energia atingiu 64,0\%, considerando a recomendação de 2073 kcal (RDA 1989). Nesse caso, os operadores de telemarketing consumiam mais calorias do que a população do estudo citado (GALEAZZI 1999). Possivelmente, a escolaridade da população poderia influenciar o maior consumo energético. Em países latino-americanos há evidências a respeito da associação inversa entre educação e risco de obesidade em mulheres, que possivelmente apresentariam maior consumo calórico (MARTORELL et al. 1998). É possível também que tenha ocorrido aumento na ingestão devido à distribuição de alimentos no interior da família ou à alimentação no trabalho favorecer maior aquisição de gêneros alimentícios (COITINHO et al. 1991).

A composição da dieta analisada em termos de porcentagem de carboidratos, lipídios e proteínas com base no valor calórico total (\%VCT) mostrou-se estar inadequada. O consumo de lipídios estava acima do recomendado pela WHO/FAO (2003) e abaixo do prescrito para carboidratos. Em homens observou-se consumo elevado de proteínas (\%VCT), baseando-se na prescrição da WHO/FAO (2003). Verificou-se, também, o consumo de proteínas por quilograma de peso corpóreo que esteve acima do ideal. Baseando-se no fato de que teores de carboidratos e lipídeos podem não evidenciar claramente uma dieta inadequada, analisaram-se os teores de 
fibra alimentar, colesterol e lipídios insaturados. O consumo médio de fibras estava abaixo do recomendado pela WHO/FAO (2003) em mulheres e próximo do limite inferior em homens. A ingestão de lipídios insaturados estava abaixo do prescrito e o consumo de colesterol estava acima do recomendado para homens.

Os dados da última POF para o Centro - Sul do país (1996/97) indicam consumo de: lipídios $28,4 \%$, carboidratos $57 \%$ e proteínas $14,6 \%$, ou seja, próximos ao limite da recomendação. A adequação de proteínas atingiu $90 \%$ da recomendação do NRC (1989), ou seja, 0,8g/kg de peso corpóreo. O consumo de colesterol foi igual a 109,8 mg e de lipídios insaturados 16,2 gramas. Em operadores de telemarketing, verificou-se consumo mais inadequado em termos de carboidratos, lipídios, colesterol e proteínas baseando-se nos dados da população brasileira em geral (GALEAZZI 1999; MONTEIRO et al 2000).

O mesmo foi observado ao comparar os dados dessa pesquisa com os relatados em um estudo transversal por CERVATO e cols. (1997). Essas autoras verificaram que, em indivíduos residentes no município de Cotia com predomínio do gênero feminino e do grupo etário entre 20 e 40 anos, a contribuição calórica média dos macronutrientes foi igual a 56\% para carboidratos, 29\% para lipídios, 15\% para proteínas, colesterol 263 miligramas e lipídios insaturados 18,5 gramas. Ao comparar com os dados dessa pesquisa verifica-se que o consumo de colesterol das operadoras foi menor do que o identificado no estudo citado, embora os homens consumissem em maiores quantidades. Em relação aos outros macronutrientes, a dieta dos operadores mostrou-se estar mais desequilibrada do que a observada por essas autoras.

É pertinente buscar o equilíbrio entre macronutrientes na dieta a fim de garantir uma melhor composição da mesma e prevenir a obesidade e sobrepeso. As quantidades de proteínas poderiam ser reduzidas, pois há indícios de que a proteína, além do ideal, poderia sobrecarregar o trabalho renal (OMS/FAO 1998). Os carboidratos devem participar mais no fornecimento de energia e deve-se atentar para o aumento das fontes alimentares com carboidratos complexos e diminuição dos simples. Os complexos apresentariam a vantagem de fornecer fibras, algumas vitaminas e alguns minerais e de serem digeridos e absorvidos de forma mais lenta, favorecendo o equilíbrio glicêmico (OMS/FAO 1998). Há evidências de que o consumo de lipídios aumentado pode levar a doenças crônico degenerativas não-transmissíveis (OMS/FAO 1998). Além disso, 
conforme documentado por HILL e cols. (2000), a gordura dietética tem sido considerada a determinante primária da obesidade, por ser de alta densidade calórica, palatável e facilmente armazenada se consumida em excesso. Contudo, o consumo de lipídios insaturados tem sido relatado por trazer benefícios à saúde, principalmente no que concerne à redução dos níveis de colesterol sérico total e à fração LDL colesterol e aumento do HDL colesterol (OMS/FAO 1998).

Ao analisar o consumo alimentar versus os turnos de trabalho, observou-se que não foram verificadas diferenças estatisticamente significantes em termos do consumo de calorias e macronutrientes. Outros estudos também não verificaram diferenças estatisticamente significantes (ROMON et al. 1992; KNUTSSON et al. 1990; LENNERNÄS et al. 1994b; LENNERNÄS et al. 1994a; ROMON-ROUSSEAUX et al. 1985). Contudo, em homens do turno noturno nota-se aumento do consumo calórico, protéico (\%VCT) e lipídico (\%VCT) e diminuição do consumo de fibras e lipídios insaturados em relação aos outros turnos. Em mulheres do turno noturno, verificou-se ingestão diminuída de calorias, proteínas (\%VCT), lipídios insaturados, colesterol e fibras e consumo aumentado de lipídios totais (\%VCT).

Essa pesquisa ao ser comparada com dois outros estudos revela situação similar. KNUTSSON et al. (1990), em um estudo de coorte, verificou em trabalhadores suecos do gênero masculino em turnos $(n=12)$ e diurnos $(n=13)$ (média de idade $=25,6$ anos para turno diurno e 21,0 anos para em turnos) que os trabalhadores em turnos consumiam menor quantidade de fibras, apesar de não diferirem significantemente entre os turnos. MORENO e cols. (2001), em um estudo transversal com 39 motoristas de caminhão brasileiros que trabalhavam em horários fixos e em turnos irregulares, observou que os do turno irregular consumiam maiores percentis de macronutrientes e calorias em relação aos do horário fixo, contudo não diferiram significantemente.

Observam-se tendências opostas entre homens e mulheres do turno noturno em relação ao consumo alimentar, a CC e o IMC. Essas diferenças se devem possivelmente porque as mulheres poderiam ser mais pressionadas a manterem-se magras e a adesão a dietas saudáveis ocorrerem mais em mulheres do que em homens, principalmente do turno noturno (MONTEIRO e CONDE 1999).

Ao analisar os dados do QFA em relação às substâncias estimulantes, nota-se que os operadores consumiam diariamente maior porcentagem de café e café com leite e 
em maior quantidade bebida à base de cola. Segundo ARRUDA (1981), o café é o infuso mais consumido pela população brasileira, o que justificaria essa maior porcentagem de consumo. Além disso, dados da POF (1996/97) indicam maior consumo de refrigerantes nas áreas metropolitanas brasileiras (PONTES 1999).

Em relação aos turnos de trabalho, verificam-se diferenças significativas entre os turnos quanto ao consumo de refrigerante à base de cola e café. Estudos têm comprovado maior ingestão de café por trabalhadores em turnos. MORENO e cols. (2001) verificaram em motoristas de caminhão em horário de trabalho irregular consumo elevado de café em relação aos motoristas do turno regular. Provavelmente, essa maior ingestão por parte desses trabalhadores se dá por essas bebidas serem estimulantes do SNC e despertarem o alerta, o que contribuiria para evitar o cansaço e a fadiga, já que além do trabalho noturno, alguns têm outro emprego diurno.

Os dados do consumo de lanches identificaram que houve maior freqüência do consumo diário de: bebidas lácteas e sucos de frutas prontos para beber. Em relação à quantidade consumida diariamente verificou-se maior ingestão de sucos de frutas prontos para beber e frutas/barras de cereais. Uma possível explicação para consumirem mais esses alimentos é porque a forma como estava organizado o horário de pausas para a alimentação nem sempre possibilitaria uma refeição considerada adequada. As centrais davam uma pausa de 15 minutos para o lanche. Desta forma, o tempo disponível para os lanches era escasso e os trabalhadores eram forçados a tomar um lanche rápido. Os operadores freqüentemente traziam lanches ao trabalho e os alimentos preferidos eram os sucos, as frutas, as bebidas lácteas e as barras de cereais, ou seja, alimentos considerados saudáveis. A aquisição de frutas nas empresas só era possível na central B, no café da manhã. Adquirir sucos e barra de cereais era possível na lanchonete da central A e no restaurante e/ou em máquinas de venda da B. Bebidas lácteas eram disponíveis no lanche da central A (sem ônus ao operador) e no restaurante da B. OLIVEIRA e THEBAUD-MONY (1998) também identificaram que a população feminina ( $\mathrm{n}=32$ ) de 3 bairros da cidade de São Paulo (Favela São Remo, Vila Madalena e Parque Continental) costumava ingerir entre as refeições frutas, justificando esse maior consumo nessa população. Ressalta-se que apesar de consumirem esses alimentos ditos saudáveis a quantidade consumida diariamente está muito aquém do recomendado. A média do consumo diário era o equivalente a 91 mililitros de bebidas lácteas, 128 
gramas de uma fruta e 140 mililitros de suco de frutas pronto para beber. Segundo a WHO/FAO (2003), é recomendável consumir 400 gramas ou mais de frutas diariamente e de acordo com PHILIPPI e cols. (1999) é indicado ingerir três porções diárias de produtos lácteos, o que não foi encontrado nesse estudo.

Em relação ao consumo de lanches e turnos, nota-se significantemente menor consumo diário de salgadinhos/biscoitos, chicletes/balas dietéticas e sucos de frutas prontos para beber pelos trabalhadores do turno noturno e maior consumo significante de refrigerantes. O maior consumo de refrigerantes é explicado por ser uma substância estimulante, de fácil aquisição e baixo custo.

$\mathrm{O}$ menor consumo de suco de frutas e maior de refrigerantes pelos operadores do turno noturno foi citado por KNUTSSON e cols. (1990) em um estudo de coorte com trabalhadores em turnos suecos em dois diferentes momentos (um uma semana antes de iniciar o trabalho em turnos e os outros seis meses depois), mostrando que no segundo momento os trabalhadores em turnos aumentaram sua ingestão de refrigerantes e diminuíram o consumo de fibras dietéticas (proveniente de legumes, verduras e frutas). Os achados sobre consumo de salgadinhos/biscoitos mostram tendência contrário do identificada por REINBERG e cols. (1979). Nesse estudo, os trabalhadores do turno noturno tinham o comportamento de beliscar alimentos ricos em carboidratos, especialmente biscoitos. Uma possível explicação para essas diferenças é que a aquisição desses alimentos pelos operadores se desse em maior número no restaurante da central B e lanchonete da A, que estariam fechados no horário de trabalho desses indivíduos, bem como esses operadores não terem o hábito de trazerem lanches nas empresas.

Conforme foi apresentado, os resultados sobre consumo alimentar, IMC e CC não seguiram necessariamente a mesma tendência, pois enquanto em homens observaram-se altas prevalências de obesidade não foi verificado elevado consumo calórico. Desta forma, é válido justificar alguma das possíveis razões para esse fato ter ocorrido:

1) O IMC é um método de avaliação de estado nutricional atual. O peso inadequado do indivíduo significa que o ganho ou a perda de peso se deu ao longo do tempo, ou seja, são processos crônicos. Por outro lado, o inquérito recordatório 24 horas verifica quantitativamente a ingestão dietética dos dias anteriores à entrevista, 
independentemente do estado nutricional atual, isto é, pode ser superior ou inferior às necessidades nutricionais. Um dado que sustenta essa afirmação é que cerca de 24,0\% disseram modificar sua alimentação no último mês para perder peso, ou seja, o relato do consumo alimentar seria adequado a esse objetivo e, portanto, teria uma tendência diferente da identificada pelo IMC.

2) Em mulheres a adequação energética não alcançou $100 \%$ da recomendação, possivelmente poderiam estar sub-relatando (underreporting) o seu consumo alimentar. Segundo SAMARAS e cols. (1999) que estudaram o consumo alimentar versus o gasto energético entre mulheres obesas e normais, foi verificado que a prevalência de subrelatado foi maior entre obesas. Tendo em mente que a obesidade e sobrepeso tinham alta prevalência nesse estudo, pode ser que esse fato tenha ocorrido entre as mulheres

Além dessas diferentes tendências entre dados de consumo alimentar e do estado nutricional destacam-se, ainda, algumas limitações desse estudo:

1) O modo como foi escolhida a população baseou-se no número de indivíduos por turnos de trabalho. Não foi possível obter 70 trabalhadores no turno noturno e, desta forma, para conseguir um número satisfatório em relação ao total, ou seja, 210 operadores, foram acrescentados operadores do turno que estavam mais dispostos a participar da pesquisa, ou seja, os da tarde. Portanto, nessa pesquisa do conjunto de operadores prevaleceu o do turno vespertino, que representava uma população mais jovem e, entre os homens, com menor consumo calórico e com mais indivíduos normais.

2) Mudança de conduta, erros na medição e sonegação de informação durante a entrevista do inquérito recordatório 24 horas poderiam ter interferido nos dados coletados sobre o consumo alimentar. Além disso, apesar da coleta dos dados do IR24 horas ter sido realizada em 3 dias, pode ser que a variabilidade da dieta não fosse totalmente captada durante esse período. BUZZARD (1998) cita que o número de dias a serem coletados para avaliar o consumo de macronutrientes seria de 3 a 10 dias, portanto, 3 dias poderiam não ser suficientes e mais dias seriam necessários para avaliar o consumo alimentar. Soma-se a isso limitações da memória dos indivíduos e a conversão dos alimentos em nutrientes que poderiam levar a vieses dos resultados. Destaca-se também, a variabilidade intra-indivíduos em relação à quantidade de 
consumo de certos alimentos que foi observada por meio dos elevados desvios-padrões em alguns itens do QFA.

3) O fato do estudo ser transversal poderia interferir nas informações coletadas sobre a alteração de peso após o início do trabalho como operador de telemarketing e/ou em turnos, pois o processo de ganho e perda de peso aconteceria por um longo período não podendo ser retratado em estudo transversal. Não houve observação da alteração de peso por um período de tempo (estudo de coorte). Desta forma, inferir que o ganho de peso foi decorrente da profissão em um estudo transversal em que não se coletou o dado de anos na profissão pode não ser adequado. Outras pesquisas são necessárias para confirmar se o ganho de peso está relacionado com a profissão ou se o ganho de peso foi em um período anterior à entrada nesse trabalho.

4) O QFA não ter sido validado e reproduzido, o que dificulta a obtenção de dados fidedignos. WILLETT (1998) recomenda a validação e reprodução dos questionários para providenciar informações úteis da dieta habitual dos indivíduos. A comparação com um outro instrumento de inquérito alimentar pode dar condições de validar o questionário, bem como a administração do questionário antes e depois de um período da coleta dos dados do consumo alimentar poderia quantificar a reprodutibilidade do método.

5) A utilização da recomendação para nutrientes e energia da WHO/FAO ao invés de uma prescrição nacional. A própria WHO/FAO recomenda a realização de estudos de ingestões seguras para diferentes populações, pois estas podem variar de acordo com o ambiente e sociedade onde vivem. Contudo, a inexistência de recomendações de nutrientes e energia atualizadas para brasileiros dificulta a sua utilização, portanto, é necessário usar recomendações internacionais para verificar se o consumo alimentar da população estava adequado.

Além das citadas limitações do estudo, não foram encontradas muitas diferenças significantes em termos de consumo alimentar e estado nutricional em operadores de telemarketing que trabalham em turnos. Pode ser que o horário do turno noturno analisado, entre 18 e 1 hora, não apresentasse tantas diferenças significantes e horários com predomínio da madrugada poderiam ser investigados para comprovar se existem alterações no consumo alimentar e estado nutricional na população que trabalha em 
turnos. Outra justificativa para esses achados é, possivelmente, que as condições e a organização do trabalho influenciem muito mais no estado nutricional e no consumo alimentar do que apenas a característica dos turnos de trabalho. Portanto, novas pesquisas são necessárias nesse grupo populacional relacionando possíveis fatores da organização e condições de trabalho que poderiam alterar o consumo alimentar e o estado nutricional em operadores de telemarketing.

\section{6) CONCLUSÕES}

Os principais resultados obtidos nessa pesquisa evidenciam que os operadores de telemarketing submetidos a 3 turnos de trabalho:

Eram em sua maioria formados por mulheres jovens, com curso universitário incompleto. Os homens eram mais velhos e predominavam no turno noturno.

As taxas de obesidade em homens foram maiores do que a PNSN em todas as faixas etárias. Em mulheres, concentraram-se nas faixas etárias superiores ou iguais a 25 anos. $\mathrm{O}$ risco muito aumentado de doenças crônicas associadas à obesidade abdominal foi mais prevalente em homens e de faixas etárias entre 19-24 anos e maior igual a 35 anos.

Os fatores do ambiente que poderiam influenciar no ganho de peso foram: aumento da obesidade na sociedade de uma forma geral, condições e forma de organização do trabalho, fatores dietéticos, como composição da dieta em termos de macronutrientes e quantidade de fibra, relacionados à saciedade.

A dieta mostrou-se, em termos da média do consumo, estar em relação a \%VCT para lipídios acima do recomendado pelas WHO/FAO e para carboidratos, lipídios insaturados e fibras abaixo do prescrito. Em homens observou-se consumo elevado do percentil de proteínas em relação ao recomendado pela WHO/FAO. O consumo calórico não alcançou as recomendações para mulheres e em homens estava adequado. Os homens consumiram dieta com altos teores de colesterol e acima do recomendado pela WHO/FAO.

Os dados do QFA em relação ao consumo diário de substâncias estimulantes identificaram maior consumo de café, café com leite e refrigerante à base de cola. Os 
lanches mais consumidos diariamente foram: suco de frutas pronto para beber, bebidas lácteas e frutas/barras de cereais.

Foram observadas diferenças significantes em relação aos turnos entre as seguintes variáveis: faixa etária, gênero, possuir outro emprego, fumo, IMC em mulheres e consumo de café, refrigerante à base de cola, refrigerantes, chicletes/balas dietéticas, suco de frutas pronto para beber e salgadinhos/biscoitos. As possíveis razões para não haver diferenças significantes na maioria dos dados analisados (IR24 horas) pode ser porque as condições e a organização do trabalho influenciem muito mais no estado nutricional e no consumo alimentar do que apenas a característica dos turnos de trabalho.

Tendências contrárias no consumo de energia e IMC ocorreram provavelmente devido a: inquérito recordatório 24 horas retratar consumo alimentar atual e IMC identificar processo crônico e características inerentes às mulheres.

As limitações do estudo foram: maior número de indivíduos do turno vespertino, limitações do inquérito recordatório 24 horas, realização de um estudo transversal com inferência sobre ganho de peso em um período, não reprodutibilidade e validade do QFA e utilização de recomendações internacionais ao invés de nacionais.

Ressalta-se que um cuidado especial em relação à alimentação deveria ser dado aos trabalhadores do turno noturno, em ordem de melhorar o estado nutricional desses trabalhadores, pois estão com maior risco de sofrerem de sobrepeso e obesidade, sobretudo em homens.

Recomenda-se que as centrais estimulem os operadores a terem hábitos alimentares saudáveis para evitar a ocorrência de doenças crônicas degenerativas não transmissíveis (como diabetes, hipertensão, doenças cardiovasculares etc). Eles poderiam aumentar sua freqüência alimentar ingerindo entre as refeições maiores quantidades diariamente de lanches com baixo valor calórico, ricos em vitaminas, minerais, fibras e proteínas e pobres em gordura, bem como poderiam ingerir mais líquidos, com a finalidade de melhorar o estado nutricional e evitar o ganho de peso decorrente das funções do trabalho. As empresas poderiam, por exemplo, modificar o lanche servido aos operadores, inserindo novos alimentos, como por exemplo: frutas, bem como substituir o leite integral pelo leite desnatado ou semi-desnatado e a margarina e manteiga pela margarina light ou creme vegetal, já que o custo desses 
produtos é praticamente o mesmo. Além disso, deveriam incentivar a atividade física no trabalho e fora do trabalho, para diminuir o sedentarismo e melhorar as condições de saúde e de vida desses trabalhadores. 


\section{7) REFERÊNCIAS BIBLIOGRÁFICAS ${ }^{8}$}

Amelsvoort LGPM, Schouten EG, Kok FJ. Duration of shiftwork related to body mass index and waist to hip ratio. Int J Obesity 1999; 23: 973-978.

Arruda BKGA. Padrões e Hábitos Alimentares da População Brasileira. Rio de Janeiro: Ministério da Saúde - Instituto Nacional de Alimentação e Nutrição - INAN; 1981.

Boggild H, Knutsson A. Shift work, risk factors and cardiovascular disease. Scan J Work Environ Health 1999; 25 (2):85-9.

Berquó ES, Souza JMP, Gotlib SLD. Bioestatística. São Paulo: EPU; 1980.

Brasil. Ministério da Saúde. Coordenação de doenças cardiovasculares. Doenças Cardiovasculares no Brasil - Sistema Único de Saúde (SUS). Brasília: Ministério da Saúde; 1993.

Buzzard M. 24-Hour Recall and Food record Methods. In: Willett W. Nutritional Epidemiology. $2^{\text {th }}$ edition. New York: Oxford University Press; 1998. p. 50-73.

Callaway CW, Chumlea WC, Bouchard C, Himes JH, Lohaman TG, Martin AD et al. Circumferences. In: Lohman TG, Roche AF, Martorell R. Anthropometric Standardization Reference Manual. Illinois: Ed. Human Kinetics Books; 1988. p. 3954.

Cervato AM, Mazzili RN, Martins IS, Marucci MFN. Dieta habitual e fatores de risco para doenças cardiovasculares. Rev Saúde Publica 1997; 31(3): 227-35.

\footnotetext{
${ }^{8}$ De acordo com o preconizado pela Faculdade de Saúde Pública/Universidade de São Paulo. Guia de Apresentação de Teses. São Paulo: Cir - Centro de Informação e Referência; 2001.
} 
Christakis G. Nutritional assessment in health programs. Am J Public Health. 1979; 63: 80 .

Coitinho DC, Leão MM, Recine E, Sichieri R. Condições Nutricionais da população brasileira: adultos e idosos - Pesquisa Nacional sobre saúde e Nutrição. Brasília: Ministério da Saúde - Instituto Nacional de Alimentação e Nutrição; 1989.

Costa G. Effects on health and well-being. In: Colquohoun WP, Costa G, Folkard S, Knauth P. Shiftwork - Problems and solutions. Frankfurt am Main: Peter Lang; 1996. p. 113-39.

Darby I. Happier staff keep call centers contented. Marketing 2000; 20: 31-32.

De Hoog S. Avaliação do Estado Nutricional. In: Mahan LK, Escott-Stump S. Krause Alimentos, Nutrição e Dietoterapia. $9^{\text {a }}$ ed. São Paulo: Roca; 1998.

Duchon JC, Keran CM. Relations among shiftworkers eating habits, eating satisfaction, and self-reported health in a population of US miners. Work \& Stress 1990; 4(2): 111120.

Dwyer JT. Dietary Assessment. In: Shils ME, Olson JÁ, Skike M. Modern nutrition health and disease. Philadelphia: Lea \& Febiger; 1994. p. 842-60. Vol I.

Ell E, Camacho LAB, Chor D. Perfil antropométrico de funcionários de banco estatal no estado do Rio de Janeiro/Brasil: I- Índice de Massa Corporal e Fatores de risco sóciodemográficos. Cad Saúde Pública 1999; 15 (1): 113-21.

Fialho F, Santos N. Manual de Análise Ergonômica do Trabalho. $2^{\mathrm{a}}$ ed. Curitiba: Ed Gênesis; 1997.

Frese M e Harwich C. Shiftwork and lenght and quality of sleep. J Occup Med 1984; 26(8): 561-566. 
Frisancho RA. Antropometric standards for the assessment of growth and nutritional status. An Arbor: The University of Michigan Press; 1990.

Galeazzi MA. Aplicações e Limitações ao uso das pesquisas de orçamentos familiares. In: Instituto Danone. Simpósio sobre Consumo Alimentar: as grandes bases de informação. Rio de Janeiro: Instituto Danone; 1999. p.63-72.

Gaspar S, Moreno C, Menna-Barreto L. Os plantões médicos, o sono e a ritmicidade biológica. Rev Ass Med Brasil 1998; 44 (3):239-45.

Geliebter A, Gluck ME, Tanowitz M, Aronoff MS, Zammit GK. Work-shift period and weight change. Nutrition 2000; 16: 27-29.

Gibson RS. Principles of nutritional assessment. New York: Oxford University Press; 1990.

Gordon CC, Chumlea WC, Roche AF. Stature, Recumbent Lenght and Weight. In: Lohman TG, Roche AF, Martorell R. Anthropometric Standardization Reference Manual. Illinois: Ed. Human Kinetics Books; 1988. p. 3-8.

Grandjean E. Manual de Ergonomia - Adaptando o trabalho ao homem. 4 a ed. Porto Alegre: Bookman; 1998.

Handjiex SV. Study on coronary risk factors and metabolic diseases among shift and night workers. In: Proceedings of the IX International Symposium on night and Shift Work; 1989; Verona, Italy. Verona: Peter Lang; 1989.p. 376-9.

Houssais AV e Salles M. Minidicionário Houssais de Língua Portuguesa. Rio de Janeiro: Ed. Objetiva; 2001. 
Hill JÔ et al. Dietary fat and regulation of energy balance implications for obesity. J Nutr 2000; 130s: 284s-8s.

ILO - International Labour Organization. Social problems of shiftwork. Genebra: SWTSW; 1977. (Working Paper ${ }^{\circ}{ }^{2}$ ).

Jeliffe D. Evaluación del estado nutricion de la comunidad. Ginebra; Organization Mundial de la Salud (OMS); 1968. (Série de monografias 53)

Jiménez LG, Martíns-Moreno JM. Cuestionário de frecuencia de consumo alimentario. In: Serra Majem LI, Bartrina JA, Verdú JM. Nutrición y Salud Publica: métodos, bases científicas y aplicaciones. Barcelona: Masson; 1995 p. 120-125.

Kleitman N. Sleep and wakefulness. Chicago: University of Chicafo Press; 1963.

Knauth P. Categories and parameters of shiftwork systems. In: Colquhoun WP, Costa G, Folkard S, Knauth P. Shiftwork - Problems and solutions. Frankfurt am Main: Peter Lang; 1996. p. 17-27.

Knutsson A, Andersson H, Berglund U. Serum lipoproteins in day and shift workers: a prospective study. Br J Ind Med 1990; 47:132-4.

Laitinen J. Nutrition and shiftworkers. Tyoterveiset - Newsletter of the Finnish institute of occupational health 1997; 16 June: 18-19.

Laitinen J, Ek E, Sovio U. Stress-related eating and drinking behavior and Body Mass Index and predictors of his behavior. Prev Medicine 2002; 29-39.

Lavie P. The enchanted world of sleep. New Haven: Yale University Press; 1996.

Lennernäs M, Åkerstedt T, Hambræus LF. Nutrient intake in day workers and shift workers. Work \& Stress 1994a; 8 (4): 332-42. 
Lennernäs M, Åkerstedt T, Hambræus LF. Nocturnal eating and serum cholesterol of three-shift workers. Scand J Work Environ Health 1994b; 20: 401-6.

Lohman TG, Roche AF, Martorell R. Anthropometric Standardization Reference Manual. Illinois: Ed. Human Kinetics Books; 1988. p. 39-54.

Marques MD, Golombeckm D, Moreno C. Adaptação temporal. In: Marques N, MennaBarreto L. Cronobiologia: Princípios e Aplicações. São Paulo: EDUSP; 1997. p. 4584.

Martorel R et al. Obesity in Latin American women and children. J Nutr 1998; 128: 1464-73.

Mataix Verdú J e Lopis González J. Evaluación del estado nutricional. In: Serra Majem LI, Bartrina JA, Verdú JM. Nutrición y Salud Publica: métodos, bases científicas y aplicaciones. Barcelona: Masson; 1995. p.73-89.

Matias AM, Neto AMP, Nascimento AA, Livramento BM, Souza E, Pereira FLS, et al. CBO - Classificação Brasileira de Ocupações - 4223: Operador de Telemarketing. [on line]. Brasília $\quad$ (DF); 2002. Disponível em <URL:http://www.mtecbo.gov.br/index.htm> [2002 abr 22]

Microsoft $^{\circledR}$. Excel [programa de computador]. Versão 2000. São Paulo: Microsoft; 2000.

Mondini L, Monteiro CA. Mudanças no padrão de alimentação. In: Monteiro CA. Velhos e novos males da saúde no Brasil: a evolução do país e suas doenças. São Paulo: Hucitec/Nupens; 1995. P. 79-89. 
Monteiro CA, Conde WL. A tendência secular e obesidade segundo estratos sociais: Nordeste e Sudeste do Brasil, 1975-1989-1997. Arq Bras Endocrinol Metab 1999; 43 (3): 186-94.

Monteiro CA, Benício MHD’A, Conde WL, Popkin BM. Shifting obesity trends in Brazil. Eur J Clin Nutr 2000; 54: 342-6.

Moreno CRC, Fischer MF, Menna-Barreto L. Aplicações da Cronobiologia. In: MennaBarreto L, Marques N. Cronobiologia: Princípios e aplicações. São Paulo: EDUSP; 1997. p. 239-54.

Moreno CRC, Cristofoletti MF, Pasqua IC. Turnos Irregulares de trabalho e sua influência nos hábitos alimentares e de sono: $\mathrm{O}$ caso dos motoristas de caminhão. Rev Abramet 2001, 36; (Jan/Fev):17-24.

Nakamura K, Shimai S, Kikuchi S, Tominaga K, Takahashi H, Tanaka M, et al. Shift work and risk factors for coronary disease in Japanese blue-collar workers: Serum lipids and anthropometric characteristics. Occup Med 1997; 47(3): 142-146.

Niedhammer I, Lert F, Marne MJ. Prevalence of overweight and weight gain in relation to night work in a nurses' cohort. Int J Obesity 1996; 20: 625-33.

National Research Council (NRC). Recommended dietary allowances. $10^{\text {th }}$ edition. Washington: National Academy Press; 1989.

Oliveira SP, Thébaud-Mony A. Hábitos e práticas alimentares em 3 localidades da cidade de São Paulo (Brasil). Rev Nutr Campinas 1998; 11 (1): 37-50.

Organização Mundial da Saúde (OMS)/Organização de alimentos e agricultura das Nações Unidas (FAO)/Organização das Nações Unidas (ONU). Necessidades de energia e proteínas. São Paulo: Roca; 1998. (Série de relatos técnicos no. 724) 
Organización Mundial de la Salud (OMS)/Food and Agriculture Organization (FAO). Informe de uma reunión consultiva conjunta. Preparación y uso de directrices nutricionales balseadas em los alimentos. Geneva: Organización Mundial de la Salud; 1998 (Série de informes técnicos no. 880)

Pao EM, Cypel YS. Cálculo de la Ingesta alimentaria. In: Ziegler EE, Filer jr LJ. Conocimentos actuales sobre nutrición. $7^{\text {a }}$ ed. Ilsi Press/OPAS. Washington, 1997. (Publicación Cientifica 565)

Peckenpaugh NJ, Poleman CM. Nutrição: essência e dietoterapia. São Paulo: Roca; 1997.

Phillippi ST, Szarfarc SC, Laterzza AR. Virtual Nutri - Sistema de Análise Nutricional [programa de computador]. Depto de Nutrição FSP- USP. Versão 1.0 for Windows. São Paulo: Depto de Nutrição FSP- USP; 1996.

Phillippi ST, Laterzza AR, Cruz ATR, Ribeiro LC. Pirâmide Alimentar adaptada: guia para escolha dos alimentos. Rev Nutr Campinas 1999; 12 (1): 65-80.

Pontes NS. A informação de consumo alimentar os dados da POF 1995-1996. In: Instituto Danone. Simpósio sobre Consumo Alimentar: as grandes bases de informação. Rio de Janeiro: Instituto Danone; 1999. p.47-52.

Popkin BM e Doak CM. The obesity epidemic is a worldwide phenomenon. Nutr Reviews 1998; 56 (4):106-14.

Prescott M. Health and eating among shiftworkers. Occup Health 1995; May: 166-68.

Presser HB. Toward a 24-hour economy. Science 1999; 284: 1178-9.

Raab DM, Rocha LE. Psychosocial aspects of the work of female call center operators in a Bank of São Paulo, Brazil. Psyche 2002; 11 (2): 109-20. 
Reinberg A, Migrane C, Apfelbaum M, Brigant L, Ghata J, Vieux N, Laporte A, Nicolai. Circadian and ultradian rhytms in feeding behaviour and nutrinet intakes of oil refinery operators with shift - work every 3-4 days. Diabete \& Metabolisme 1979; 5: $33-41$.

Reinberg A. Chronobiology and nutrition. In: Reinberg A and Smolensky M H. Biological rhytms and medicine: Celular, Metabolic, Phisiopathologic and Pharmacologic Aspects. New York: Spreinger-Verlog; 1983. p. 265-298.

Rodrigues EM, Ruffino Neto A. Tendência do tabagismo entre estudantes da Universidade de São Paulo, Campus de Ribeirão Preto, no período de 1980-1988. Medicina (Ribeirão Preto) 1991; 24 (3):149-58.

Romon M, Beuscart R, Frimat P, Debry G, Furon D. Apport calorique et prise de poids selon le type de rotation chez des travailleurs postés. Rev Epiém et Santé Publ 1986; 34: 324-331.

Romon M. Nuttens MC, Fievet C, Pot P, Bard JM. Increased trigliceride levels in shiftworkers. Am J Med 1992; 93: 259-62.

Romon-Rousseaux M, Beuscart R, Thuilliez JC, Frimat P, Furon D. Influence of diferent shift schedules on eating behaviour and weight in edible oil refinary workers. In: Proceedings of the VII International Symposium on night and shiftwork; 1985; Igles (AU); 1985. p. 433-40.

Samaras K, Kelly PJ, Campbell LV. Dietary underreporting is prevalent in middle-aged Brutish women and is not related to adiposity (percentage body fat). Int J Obes 1999; 23: 881-8. 
Serra Majem LI. e Ribas B. Recordatorio de 24 horas. In: Serra Majem LI, Bartrina JA, Verdú JM. Nutrición y Salud Publica: métodos, bases científicas y aplicaciones. Barcelona: Masson; 1995. p. 113-119.

Sindicatos dos Trabalhadores em Telemarketing. Trabalho e saúde dos trabalhadores em telemarketing. São Paulo: Sintratel; 2001.

Stata Corporation. Stata (Statistics Data Analysis) [computer program]. Version 6.0. Texas: Stata Corporation; 2000.

Stewart AJ e Wahlqvist ML. Effect of shiftwork on canteen food purchase. J Occup Med 1985; 8: 552-554.

Tepas DI. Do eating and drinking habits interact with work schedule variables? Work \& Stress 1990; 4 (3): 203-11.

Thiago C. Avaliação Nutricional de Trabalhadores em Turnos. São Paulo; 2000. [Mestrado - PRONUT - Faculdade de Saúde Pública, Faculdade de Farmácia e Bioquímica e Faculdade de Economia e Administração da USP].

Thompson FE, Byers T. Dietary assessment resource manual. J Nutr 124 (11s), 1994.

Toomingas A. et al. Symptoms and clinical findings from the musculoskeletal system among operators at a call center in Sweden - a 10 month follow-up study. National Institute for Working Life; 2002.

Turner M. Shiftwork strategies. The Cand Nurse 1995; Dec: 41-2.

US Congress - Office of Technology Assessment. Biological Rhytms: Implications for the worker (OTA-BA-463). Washington: US Government Priting Office; 1991. 
Vasconcelos FAG. Avaliação Nutricional de Coletividades. Florianópolis: Ed. UFSC; 1993.

Waterhouse J, Minors D, Atkinson G, Benton D. Chronobiology and meal times intermeal and external factors. Br J Nutr 1997; 77 (1): S29-S38.

World Health Organization (WHO). Preparation and use of food-based dietary guidelines. Geneva: WHO; 1988. (Technical report series 880)

World Health Organization (WHO). Physical status: the use and interpretation of anthropometric. Geneva: WHO; 1995. (Technical report series 854)

World Health Organization (WHO). Obesity: preventing and managing the global epidemic. Geneva: WHO; 2000. (Technical report series 894)

World Health Organization (WHO)/Food and Agriculture Organization (FAO). Diet, nutrition and the prevent of chronic diseases. Geneva: WHO; 2003. (Technical report series 916)

Willett W. Food Frequency Methods. In: Willett W. Nutritional Epidemiology. $2^{\text {th }}$ edition; New York: Oxford University Press; 1998. p. 101-56.

Zabotto $\mathrm{CB}$ et al. Registro Fotográfico para Inquéritos Dietéticos - utensílios e porções. Goiânia: Nepa - Unicamp - DNUT - UFG; 1996. 
1.Anexo - Questionário Aplicado 


\section{I) IDENTIFICAÇÃO}

Data:

1) Número na pesquisa:

2) Data de nascimento:

3) Idade: anos

4) Sexo: $1 \square$ Masculino $2 \square$ Feminino

5) Estado marital: $1 \square$ Solteiro $\quad 2 \square$ Vive com companheiro $3 \square$ Casado $4 \square$ Viúvo $5 \square$ Separado

6) Têm filhos? $1 \square$ Sim $\quad 2 \square$ Não

7) Se sim, quantos? filho (s)

8) Qual o horário do seu turno de trabalho? De a horas.

9) Possui outro emprego? $1 \square$ Masculino $2 \square$ Feminino

10) Se sim, qual o horário? De a :__ horas.

11) Está estudando atualmente? $1 \square$ Sim $\quad 2 \square$ Não

12) Se sim, qual o horário? De a __ : _ horas.

13) Qual o seu grau de escolaridade?

$1 \square$ Ensino Fundamental incompleto (Primeiro grau incompleto)

$2 \square$ Ensino Fundamental completo (Primeiro grau completo)

$3 \square$ Ensino Médio incompleto (Segundo grau incompleto)

$4 \square$ Ensino Médio completo (Segundo grau completo)

$5 \square$ Superior Incompleto

$6 \square$ Superior Completo

$7 \square$ Pós-graduação 


\section{II) ESTILO/HÁBITOS DE VIDA}

14) O Sr. (a) fumou mais de 20 maços de cigarros (ou cachimbo, charuto) em toda a sua vida?

$1 \square$ Não (pule para questão 16)

$2 \square$ Sim e eu fumo atualmente

$3 \square$ Sim, mas parei de fumar

15) Se fuma ou fumou por quanto tempo?

$1 \square$ menos de 10 anos

$4 \square 31$ a 40 anos

$2 \square 11$ a 20 anos

$3 \square 21$ a 30 anos

16) Quantos cigarros em média o Sr. (a) fuma ou fumava por dia?

a) cigarros

b) charutos

c) cachimbos

17) Se o Sr.(a) parou de fumar, há quanto tempo isso ocorreu?

$1 \square$ menos de 1 ano

$4 \square 6$ a 10 anos

$2 \square 1$ a 2 anos

$5 \square 11$ a 20 anos

$3 \square 3$ a 5 anos

$6 \square$ mais de 20 anos

18) O Sr. (a) toma algum tipo de bebida alcoólica?

$1 \square \operatorname{sim}$ $2 \square$ não (pule para questão 19)

19) Qual a bebida alcoólica o Sr. (a) toma?

$1 \square$ vinho $\quad 2 \square$ cerveja $\quad 3 \square$ aguardente $\quad 4 \square$ Outra. Qual?

20) Com que freqüência é esse seu consumo?

\begin{tabular}{|c|l|l|}
\hline PORÇÃO & \multicolumn{1}{|c|}{ NÜMERO DE } & \multicolumn{1}{|c|}{ FREQÜÊNCIA } \\
\hline VEZES & \\
\hline copo (s) & & $\square$ por dia \\
lata (s) & & por semana \\
\hline garrafa pequena (s) & & $\square$ por mês \\
garrafa grande (s) & & $\square$ a cada 2 meses \\
\hline
\end{tabular}

21) Você toma algum tipo de medicamento para manter-se acordado?

$1 \square \operatorname{sim}$. Qual?

$2 \square$ não (pule para questão 21 )

22) Com que frequiência é esse seu consumo?

\begin{tabular}{|c|l|l|}
\hline PORÇÃO & \multicolumn{1}{|c|}{ NÚMERO DE } & \multicolumn{1}{|c|}{ FREQÜÊNCIA } \\
& VEZES & \\
\hline comprimido (s) & & $\square$ por dia \\
cápsula (s) & & $\square$ por semana \\
& & $\square$ por mês \\
& & \\
& & a cada 2 meses \\
\hline
\end{tabular}


23) Você toma algum tipo de medicamentos para dormir?

$1 \square \operatorname{sim}$. Qual?

$2 \square$ não (pule para questão 21)

24) Com que frequiência é esse seu consumo?

\begin{tabular}{|c|l|l|}
\hline PORÇÃO & \multicolumn{1}{|c|}{ NÚMERO DE } & \multicolumn{1}{|c|}{ FREQÜÊNCIA } \\
& VEZES & \\
\hline comprimido (s) & & $\square$ por dia \\
cápsula (s) & & $\square$ por semana \\
& & $\square$ por mês \\
& & a cada 2 meses \\
\hline
\end{tabular}

\section{III) QUESTIONÁRIO DE FREQÜENCIA ALIMENTAR}

\begin{tabular}{|c|c|c|c|}
\hline ALIMENTOS & PORÇÕES & $\begin{array}{c}\text { NÚMERO DE } \\
\text { VEZES }\end{array}$ & FREQÜÊENCIA \\
\hline $\begin{array}{l}25-\quad \text { Você toma } \\
\text { refrigerante a base de } \\
\text { cola (Coca-cola e } \\
\text { Pepsi)? } \\
\square \text { SIM } \\
\square \text { NÃO }\end{array}$ & $\begin{array}{l}\text { copo }(\mathrm{s}) \\
\text { lata }(\mathrm{s}) \\
\text { garrafa pequena }(300 \mathrm{ml}) \\
\text { garrafa grande }(600 \mathrm{ml})\end{array}$ & & $\begin{array}{l}\square \text { por dia } \\
\square \text { por semana } \\
\square \text { por mês } \\
\square \text { a cada } 2 \text { meses }\end{array}$ \\
\hline $\begin{array}{l}26-\quad \text { Você toma } \\
\text { refrigerante a base de } \\
\text { guaraná? } \\
\square \text { SIM } \\
\square \text { NÃO }\end{array}$ & $\begin{array}{l}\text { copo }(\mathrm{s}) \\
\text { lata }(\mathrm{s}) \\
\text { garrafa pequena }(300 \mathrm{ml}) \\
\text { garrafa grande }(600 \mathrm{ml})\end{array}$ & & $\begin{array}{l}\square \text { por dia } \\
\square \text { por semana } \\
\square \text { por mês } \\
\square \text { a cada } 2 \text { meses }\end{array}$ \\
\hline $\begin{array}{l}\text { 27- Você toma outro } \\
\text { tipo de refrigerante? } \\
\square \text { SIM } \\
\square \text { NÃO }\end{array}$ & $\begin{array}{l}\text { copo }(\mathrm{s}) \\
\text { lata }(\mathrm{s}) \\
\text { garrafa pequena }(300 \mathrm{ml}) \\
\text { garrafa grande }(600 \mathrm{ml})\end{array}$ & & $\begin{array}{l}\square \text { por dia } \\
\square \text { por semana } \\
\square \text { por mês } \\
\square \text { a cada } 2 \text { meses }\end{array}$ \\
\hline 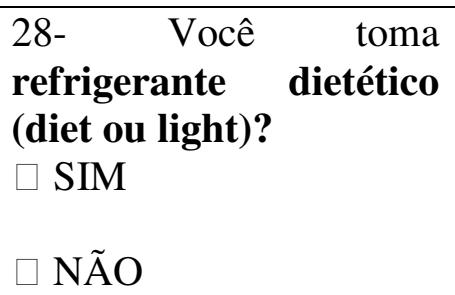 & $\begin{array}{l}\text { copo }(\mathrm{s}) \\
\text { lata }(\mathrm{s}) \\
\text { garrafa pequena }(300 \mathrm{ml}) \\
\text { garrafa grande }(600 \mathrm{ml})\end{array}$ & & $\begin{array}{l}\square \text { por dia } \\
\square \text { por semana } \\
\square \text { por mês } \\
\square \text { a cada } 2 \text { meses }\end{array}$ \\
\hline $\begin{array}{l}\text { 29- Você toma chá } \\
\text { preto? } \\
\square \text { SIM } \\
\square \text { NÃO }\end{array}$ & $\begin{array}{c}\text { copo (s) } \\
\text { lata (s) } \\
\text { xícara (s) } \\
\text { copinho descartável }\end{array}$ & & $\begin{array}{l}\square \text { por dia } \\
\square \text { por semana } \\
\square \text { por mês } \\
\square \text { a cada } 2 \text { meses }\end{array}$ \\
\hline
\end{tabular}




\begin{tabular}{|c|c|c|}
\hline $\begin{array}{l}\text { 30- Você toma chá } \\
\text { mate? } \\
\square \text { SIM } \\
\square \text { NÃO }\end{array}$ & $\begin{array}{l}\text { copo }(\mathrm{s}) \\
\text { lata }(\mathrm{s}) \\
\text { xícara }(\mathrm{s}) \\
\text { copinho descartável }\end{array}$ & $\begin{array}{l}\square \text { por dia } \\
\square \text { por semana } \\
\square \text { por mês } \\
\square \text { a cada } 2 \text { meses }\end{array}$ \\
\hline $\begin{array}{l}\text { 31- Você toma } \\
\text { tipo de chá? } \\
\begin{array}{lll}\square & \text { SIM. } & \text { Qual? }\end{array} \\
\end{array}$ & $\begin{array}{l}\text { copo (s) } \\
\text { xícara }(\mathrm{s}) \\
\text { copinho descartável }\end{array}$ & $\begin{array}{l}\square \text { por dia } \\
\square \text { por semana } \\
\square \text { por mês } \\
\square \text { a cada } 2 \text { meses }\end{array}$ \\
\hline$\square$ NÃO & & \\
\hline $\begin{array}{l}\text { 32- Você toma leite com } \\
\text { café (pingado)? } \\
\square \text { SIM } \\
\square \text { NÃO }\end{array}$ & $\begin{array}{c}\text { copo }(\mathrm{s}) \\
\text { xícara }(\mathrm{s})\end{array}$ & $\begin{array}{l}\square \text { por dia } \\
\square \text { por semana } \\
\square \text { por mês } \\
\square \text { a cada } 2 \text { meses }\end{array}$ \\
\hline $\begin{array}{l}\text { 33- Você toma café } \\
\text { preto? } \\
\square \text { SIM. Tipo de café: } \\
\\
\square \text { NÃO }\end{array}$ & $\begin{array}{l}\text { copo (s) } \\
\text { xícara (s) } \\
\text { copinho descartável }\end{array}$ & $\begin{array}{l}\square \text { por dia } \\
\square \text { por semana } \\
\square \text { por mês } \\
\square \text { a cada } 2 \text { meses }\end{array}$ \\
\hline $\begin{array}{l}\text { 34- Você toma leite com } \\
\text { achocolatado? } \\
\square \text { SIM } \\
\square \text { NÃO }\end{array}$ & $\begin{array}{r}\text { copo }(\mathrm{s}) \\
\text { xícara }(\mathrm{s})\end{array}$ & $\begin{array}{l}\square \text { por dia } \\
\square \text { por semana } \\
\square \text { por mês } \\
\square \text { a cada } 2 \text { meses }\end{array}$ \\
\hline $\begin{array}{l}\text { 35- Você come } \\
\text { chocolate em barra? } \\
\square \text { SIM } \\
\square \text { NÃO }\end{array}$ & $\begin{array}{c}\text { barra }(\mathrm{s}) \text { pequena }(\mathrm{s}) \\
\text { barra }(\mathrm{s}) \text { média }(\mathrm{s}) \\
\text { barra }(\mathrm{s}) \text { grande }(\mathrm{s})\end{array}$ & $\begin{array}{l}\square \text { por dia } \\
\square \text { por semana } \\
\square \text { por mês } \\
\square \text { a cada } 2 \text { meses }\end{array}$ \\
\hline $\begin{array}{l}\text { 36- Você toma guaraná } \\
\text { em pó? } \\
\square \text { SIM } \\
\square \text { NÃO }\end{array}$ & $\begin{array}{l}\text { cápsula }(\mathrm{s}) \\
\text { colher }(\mathrm{s}) \text { de café }(\mathrm{s})\end{array}$ & $\begin{array}{l}\square \text { por dia } \\
\square \text { por semana } \\
\square \text { por mês } \\
\square \text { a cada } 2 \text { meses }\end{array}$ \\
\hline 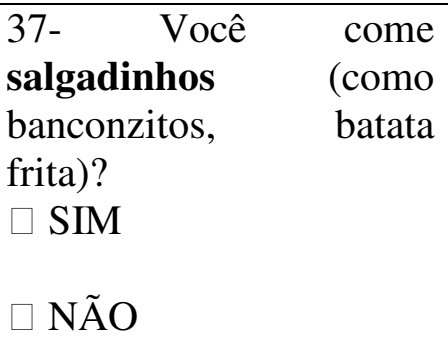 & $\begin{array}{l}\text { unidade }(\mathrm{s}) \\
\text { pacote pequeno }(\mathrm{s}) \\
\text { pacote médio }(\mathrm{s}) \\
\text { pacote grande }(\mathrm{s})\end{array}$ & $\begin{array}{l}\square \text { por dia } \\
\square \text { por semana } \\
\square \text { por mês } \\
\square \text { a cada } 2 \text { meses }\end{array}$ \\
\hline $\begin{array}{l}\text { 38- Você come biscoito } \\
\text { ou bolacha? } \\
\square \text { SIM }\end{array}$ & $\begin{array}{c}\text { unidade }(\mathrm{s}) \\
\text { pacote }(\mathrm{s})\end{array}$ & $\begin{array}{l}\square \text { por dia } \\
\square \text { por semana } \\
\square \text { por mês } \\
\square \text { a cada } 2 \text { meses }\end{array}$ \\
\hline$\square$ NÃO & & \\
\hline
\end{tabular}




\begin{tabular}{|c|c|c|}
\hline $\begin{array}{l}\text { 39- Você come fruta? } \\
\square \text { SIM } \\
\square \text { NÃO }\end{array}$ & $\begin{array}{l}\text { unidade (s) } \\
\text { fatia (s) }\end{array}$ & $\begin{array}{l}\square \text { por dia } \\
\square \text { por semana } \\
\square \text { por mês } \\
\square \text { a cada } 2 \text { meses }\end{array}$ \\
\hline $\begin{array}{l}\text { 40- Você come lanche } \\
\text { (hambúrguer, } \\
\text { cheeseburguer, cachorro } \\
\text { quente, etc)? } \\
\square \text { SIM }\end{array}$ & _ unidade (s) & $\begin{array}{l}\square \text { por dia } \\
\square \text { por semana } \\
\square \text { por mês } \\
\square \text { a cada } 2 \text { meses }\end{array}$ \\
\hline$\square$ NÃO & & \\
\hline $\begin{array}{l}\text { 41- Você come } \\
\text { (doce doce } \\
\text { amendoim, etc)? } \\
\square \text { SIM }\end{array}$ & $\begin{array}{c}\text { unidade }(\mathrm{s}) \\
\text { fatia }(\mathrm{s}) \\
\text { pote }(\mathrm{s})\end{array}$ & $\begin{array}{l}\square \text { por dia } \\
\square \text { por semana } \\
\square \text { por mês } \\
\square \text { a cada } 2 \text { meses }\end{array}$ \\
\hline$\square$ NÃO & & \\
\hline $\begin{array}{l}\text { 42- Você come salgado? } \\
\square \text { SIM } \\
\square \text { NÃO }\end{array}$ & _ unidade (s) & $\begin{array}{l}\square \text { por dia } \\
\square \text { por semana } \\
\square \text { por mês } \\
\square \text { a cada } 2 \text { meses }\end{array}$ \\
\hline $\begin{array}{l}\text { 43- Você chupa bala? } \\
\square \text { SIM } \\
\square \text { NÃO }\end{array}$ & $\begin{array}{c}\text { unidade }(\mathrm{s}) \\
\text { pacote }(\mathrm{s}) \\
\operatorname{drops}(\mathrm{s})\end{array}$ & $\begin{array}{l}\square \text { por dia } \\
\square \text { por semana } \\
\square \text { por mês } \\
\square \text { a cada } 2 \text { meses }\end{array}$ \\
\hline $\begin{array}{l}\text { 44- Você come bala } \\
\text { dietética (diet)? } \\
\square \text { SIM } \\
\square \text { NÃO }\end{array}$ & $\begin{array}{c}\text { unidade }(\mathrm{s}) \\
\text { pacote }(\mathrm{s}) \\
\operatorname{drops}(\mathrm{s})\end{array}$ & $\begin{array}{l}\square \text { por dia } \\
\square \text { por semana } \\
\square \text { por mês } \\
\square \text { a cada } 2 \text { meses }\end{array}$ \\
\hline $\begin{array}{l}45-\quad \text { Você } \\
\text { chicletes? } \\
\square \text { SIM } \\
\square \text { NÃO }\end{array}$ & _ unidade (s) & $\begin{array}{l}\square \text { por dia } \\
\square \text { por semana } \\
\square \text { por mês } \\
\square \text { a cada } 2 \text { meses }\end{array}$ \\
\hline $\begin{array}{l}\text { 46- Você come chicletes } \\
\text { dietético (diet)? } \\
\square \text { SIM } \\
\square \text { NÃO }\end{array}$ & _ _unidade (s) & $\begin{array}{l}\square \text { por dia } \\
\square \text { por semana } \\
\square \text { por mês } \\
\square \text { a cada } 2 \text { meses }\end{array}$ \\
\hline $\begin{array}{l}\text { 47- Você come barra de } \\
\text { cereais? } \\
\square \text { SIM } \\
\square \text { NÃO }\end{array}$ & $\begin{array}{c}\text { barra (s) pequena (s) } \\
\text { barra (s) média }(\mathrm{s}) \\
\text { barra }(\mathrm{s}) \text { grande }(\mathrm{s})\end{array}$ & $\begin{array}{l}\square \text { por dia } \\
\square \text { por semana } \\
\square \text { por mês } \\
\square \text { a cada } 2 \text { meses }\end{array}$ \\
\hline
\end{tabular}




\begin{tabular}{|c|c|c|}
\hline $\begin{array}{l}\text { 48- Você toma vitamina } \\
\text { pronta para beber? } \\
\square \text { SIM } \\
\square \text { NÃO }\end{array}$ & $\begin{array}{l}\text { caixinha }(\mathrm{s}) \\
\text { lata }(\mathrm{s})\end{array}$ & $\begin{array}{l}\square \text { por dia } \\
\square \text { por semana } \\
\square \text { por mês } \\
\square \text { a cada } 2 \text { meses }\end{array}$ \\
\hline $\begin{array}{l}\text { 49- Você toma suco de } \\
\text { fruta? } \\
\square \text { SIM } \\
\square \text { NÃO }\end{array}$ & $\begin{array}{c}\text { caixinha (s) } \\
\text { lata }(\mathrm{s}) \\
\text { garrafa }(\mathrm{s})\end{array}$ & $\begin{array}{l}\square \text { por dia } \\
\square \text { por semana } \\
\square \text { por mês } \\
\square \text { a cada } 2 \text { meses }\end{array}$ \\
\hline $\begin{array}{l}\text { 50- Você come pão com } \\
\text { manteiga? } \\
\square \text { SIM } \\
\square \text { NÃO }\end{array}$ & _unidade (s) & $\begin{array}{l}\square \text { por dia } \\
\square \text { por semana } \\
\square \text { por mês } \\
\square \text { a cada } 2 \text { meses }\end{array}$ \\
\hline
\end{tabular}

51) Em relação ao seu hábito alimentar, você está:

$1 \square$ Muito satisfeito

$2 \square$ satisfeito

$3 \square$ insatisfeito

52) Em relação ao seu apetite, você sente:

$1 \square$ Muito apetite

$2 \square$ Com apetite

$3 \square$ Inapetente

53) Quantas refeições você faz por dia:
$1 \square$ Uma
$5 \square$ Cinco
$2 \square$ Duas
$6 \square$ Seis
$3 \square$ Três
$7 \square$ Muda a cada dia
$4 \square$ Muito apetite

54) Quais refeições você faz por dia:
$1 \square$ Café da manhã
$4 \square$ Lanche da tarde
$2 \square$ Lanche da manhã
$5 \square$ Jantar
$3 \square$ Almoço
$6 \square$ Lanche da noite

55) Em relação ao horário das suas refeições, você:

$1 \square$ Cada dia alimenta-se em um horário diferente

$2 \square$ Às vezes se alimenta no mesmo horário

$3 \square$ Alimenta-se todos os dias no mesmo horário

56) Seu peso alterou, depois que o Sr. (a) começou a trabalhar à noite ou em turnos?

$1 \square$ Sim, aumentou. Quantos quilos? __ kg. Qual era a sua idade?__ anos

$2 \square$ Sim, diminuiu. Quantos quilos? kg. Qual era a sua idade? anos
$3 \square$ Não
$9 \square$ Não sabe 
57) Seu peso alterou, depois que o Sr. (a) começou a trabalhar como operador de telemarketing?

$1 \square$ Sim, aumentou. Quantos quilos? _— kg. Qual era a sua idade?__ anos

$2 \square$ Sim, diminuiu. Quantos quilos?

kg. Qual era a sua idade? anos

$3 \square$ Não (pule para questão 59)

$9 \square$ Não sabe (pule para questão 59)

58) Se sim, essa variação de peso tem relação com o trabalho? Por quê?

59) O Sr. (a) mudou sua alimentação no último mês ou está fazendo algum tipo de dieta? (emagrecer ou outro motivo)?
$1 \square$ Não (pule para questão 61)
$5 \square$ Sim, para redução de sal
$2 \square$ Sim, para perder peso
$6 \square$ Sim, para redução de

colesterol

$3 \square$ Sim, por orientação médica

$4 \square$ Sim, para dieta vegetariana

$7 \square$ Sim, para ganho de peso ou redução do consumo de carnes

$9 \square$ Não sabe

60) Quanto tempo seguiu (e) essa dieta? dias.

61) Houve variação recente de peso (menos que 1 mês)?

$1 \square$ Sim. Quantos quilos? $\mathrm{kg}$.

$2 \square$ Não

$9 \square$ Não sabe

62) Aos 20 anos qual era o seu peso? $\mathrm{kg}$.

63) O fato de você não poder responder ao cliente o (a) deixa ansioso (a) a ponto de afetar o seu consumo alimentar?

$1 \square$ Sim $2 \square$ Freqüentemente $3 \square$ Às vezes $4 \square$ Raramente $5 \square$ Nunca $9 \square$ Não sabe

Não complete esse campo:

\begin{tabular}{|c|c|c|}
\hline 1) Peso: ___ & 2) Estatura: ___ & 3) Circ. Cintura: __ $\mathrm{cm}$ \\
\hline 1) Peso: ___ & 2) Estatura: ___ m & 3) Circ. Cintura: ___ $\mathrm{cm}$ \\
\hline 1) Peso: ___ & 2) Estatura: ___ m & 3) Circ. Cintura: ___ $\mathrm{cm}$ \\
\hline 1) Peso médio: ___ $k$ & Estatura média: ___ m & 3) Circ. Cintura média: \\
\hline
\end{tabular}


IV) Recordatório 24 horas

Trabalho $\square \quad$ Folga $\square$

\begin{tabular}{|c|c|c|c|}
\hline Local & Horário & Medidas caseiras & Alimentos consumidos \\
\hline & & & \\
\hline & & & \\
\hline & & & \\
\hline & & & \\
\hline & & & \\
\hline & & & \\
\hline & & & \\
\hline & & & \\
\hline & & & \\
\hline & & & \\
\hline & & & \\
\hline & & & \\
\hline & & & \\
\hline & & & \\
\hline & & & \\
\hline & & & \\
\hline & & & \\
\hline & & & \\
\hline & & & \\
\hline & & & \\
\hline & & & \\
\hline & & & \\
\hline & & & \\
\hline & & & \\
\hline & & & \\
\hline & & & \\
\hline & & & \\
\hline & & & \\
\hline & & & \\
\hline & & & \\
\hline & & & \\
\hline & & & \\
\hline & & & \\
\hline & & & \\
\hline
\end{tabular}


2.Anexo - Termo de consentimento 


\section{Termo de Consentimento}

$\mathrm{Eu}$, declaro que concordo em participar, voluntariamente, de pesquisa científica sobre “Avaliação nutricional de operadores de teleatendimento", que tem como objetivo avaliar o consumo alimentar de trabalhadores em turnos, a partir de entrevistas e questionários sobre o consumo alimentar e atividades físicas, bem como, a obtenção dos dados de peso e altura. O projeto que vem sendo realizado sob responsabilidade da mestranda Maria Fernanda Cristofoletti. Estou ciente de que os resultados são confidenciais e que serão utilizados unicamente para fins de pesquisa. Autorizo a publicação dos resultados das análises em conjunto para efeito público. Os resultados individuais somente poderão ser comunicados para minha pessoa e meu nome não será divulgado nos resultados da pesquisa.

Sei que tenho liberdade de recusar a participar da pesquisa e de deixá-la, à qualquer momento, sem que isso traga nenhum prejuízo com relação às minhas funções na empresa.

São Paulo, de de 2001.

Assinatura do pesquisado

Assinatura do pesquisador

Obs.: em caso de dúvida ou esclarecimentos, favor ligar para 5096-0409 e falar com Maria Fernanda. 
3.Anexo - Parecer do Comitê de Ética 


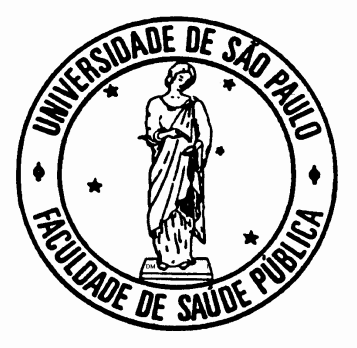

UNIVERSIDADE DE SÃO PAULO

FACULDADE DE SAÚDE PÚBLICA

COMITÊ DE ÉTICA EM PESQUISA - COEP

Av. Dr. Arnaldo, 715 - Cerqueira César

São Paulo - CEP 01246-904

Telefone: (0xx11) 3066-7779 - email: mdgracas@usp.br

\section{Of. COEP/072/01}

04 de junho de 2001

Pelo presente, informo que o Comitê de Ética em Pesquisa da Faculdade de Saúde Pública da Universidade de São Paulo - COEP, analisou e aprovou, de acordo com os requisitos da Resolução CNS/196/96, o protocolo de Pesquisa n. ${ }^{\circ}$ 436, intitulado: "AVALIAÇÃO NUTRICIONAL DE OPERADORES DE TELEATENDIMENTO", apresentado pela pesquisadora Maria Fernanda Cristofoletti.

Atenciosamente,

Paulo Antonio de Carvalho Fortes

Professor Associado

Vice-Coordenador do Comitê de Ética em Pesquisa da FSP-COEP 